\title{
Mechanically Triggered Carbon Monoxide Release with Turn-On Aggregation-Induced Emission
}

\author{
Yunyan Sun ${ }^{\#, \dagger}$, William J. Neary ${ }^{\#, \dagger}, \S$, Zachary P. Burke ${ }^{\dagger}$, Hai Qian ${ }^{\S}$, Lingyang Zhu ${ }^{\dagger}$, and Jeffrey S. \\ Moore*,†,§
}

${ }^{\dagger}$ Department of Chemistry, University of Illinois at Urbana-Champaign, Urbana, Illinois 61801, United States. ${ }^{\S}$ Beckman Institute for Advanced Science and Technology, University of Illinois at Urbana-Champaign, Urbana, Illinois 61801, United States.

\begin{abstract}
Polymers that release functional small molecules under mechanical stress potentially serve as next-generation materials for catalysis, sensing, and mechanochemical dynamic therapy. To further expand the function of mechanoresponsive materials, the discovery of chemistries capable of small molecule release are highly desirable. In this report, we detail a non-scissile bifunctional mechanophore (i.e., dual mechano-activated properties) based on a unique mechanochemical reaction involving norborn2-en-7-one (NEO). One property is the release of carbon monoxide (CO) upon pulsed solution ultrasonication. A release efficiency of $58 \%$ is observed at high molecular weights $\left(M_{\mathrm{n}}=158.8 \mathrm{kDa}\right)$, equating to $\sim 154$ molecules of $\mathrm{CO}$ released per chain. The second property is the bright cyan emission from the macromolecular product in its aggregated state, resulting in a turn-on fluorescence readout coincident with $\mathrm{CO}$ release. This report not only demonstrates a unique strategy for the release of small molecule in a nonscissile way, but also guides future design of force-responsive aggregation-induced emission (AIE) luminogens.
\end{abstract}

Carbon monoxide $(\mathrm{CO})$ is one of the deadliest chemicals in the world, sending nearly 50,000 people to the hospital per year in the US. ${ }^{1}$ In contrast, it is also widely acknowledged as an important signaling molecule akin to hydrogen sulfide $\left(\mathrm{H}_{2} \mathrm{~S}\right)$ and nitric oxide (NO) with essential physiological roles. ${ }^{2}$ Moreover, $\mathrm{CO}$ has been developed as a potential therapeutic agent due to its cytoprotective, ${ }^{3}$ antibacterial, ${ }^{4}$ antiinflammatory, ${ }^{5}$ and anticancer effects. ${ }^{6}$ As early clinical trials that administer $\mathrm{CO}$ through inhalators reported safety concerns and difficulties in delivering precise amounts of $\mathrm{CO}$ to patients, the development of safer alternatives for $\mathrm{CO}$ delivery are needed. ${ }^{7}$ CO-releasing molecules (CO-RMs) serve as a promising strategy to overcome these limitations, as they allow for the controlled release of $\mathrm{CO}$ under external stimuli such as light, ${ }^{8}$ reactive oxygen species (ROS), ${ }^{9}$ and enzymes. ${ }^{10}$ Although ongoing research in organic based CO-RMs have eliminated the use of potentially toxic metals while providing improved synthetic tunability, ${ }^{11}$ the discovery of alternative chemistries and stimuli for the release of $\mathrm{CO}$ will further help advance $\mathrm{CO}$-associated biological studies and therapeutics.

Polymer mechanochemistry is a potentially useful platform for the controlled release of small molecules for therapeutic applications, ${ }^{12-14}$ as ultrasound has the unique ability to penetrate deep within biological tissues to achieve mechanochemical transformations noninvasively with precise spatial and temporal control. ${ }^{15}$ On top of this, multimechanophore (MMP) materials that release large amounts of cargo in a highly tunable fashion are particularly attractive. ${ }^{16-21}$ We envisioned that bench-stable norborn-2-en-7one $(\mathrm{NEO})^{22}$ typically used for the cheletropic extrusion of $\mathrm{CO},{ }^{9,23}$ is a putative mechanophore for the release of $\mathrm{CO}$ when tethered to a polymer at the 5,6 positions (Scheme 1). As illustrated in Scheme 1, mechanical force transduced from the polymer backbone is hypothesized to selectively cleave the $\mathrm{C}_{5^{-}}$ $\mathrm{C}_{6}$ bond, resulting in a diradical intermediate. A subsequent $\beta$ elimination leads to the release of $\mathrm{CO}$ without backbone scission, thus allowing for multiple activations (i.e., multiple CO-release) to occur per chain. Herein, we report our findings of a CO-releasing mechanophore with concomitant turn-on aggregation-induced emission (AIE) via a fundamentally unique mechanochemical transformation.

Scheme 1. Known and Postulated CO Release Pathways from the Norborn-2-En-7-One (NEO) Scaffold ${ }^{\mathrm{a}}$

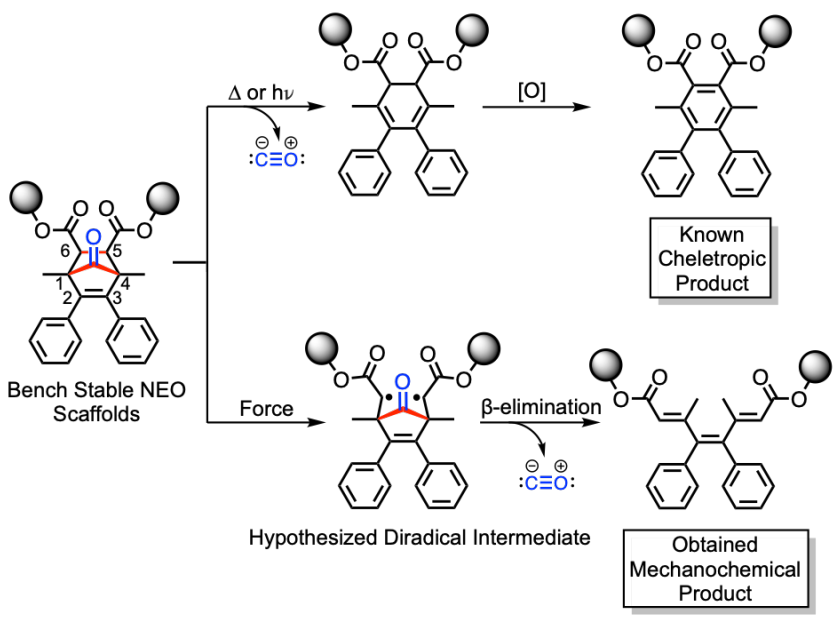

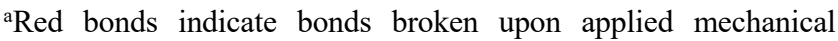
stimuli. Blue bonds indicate the small molecule released. 


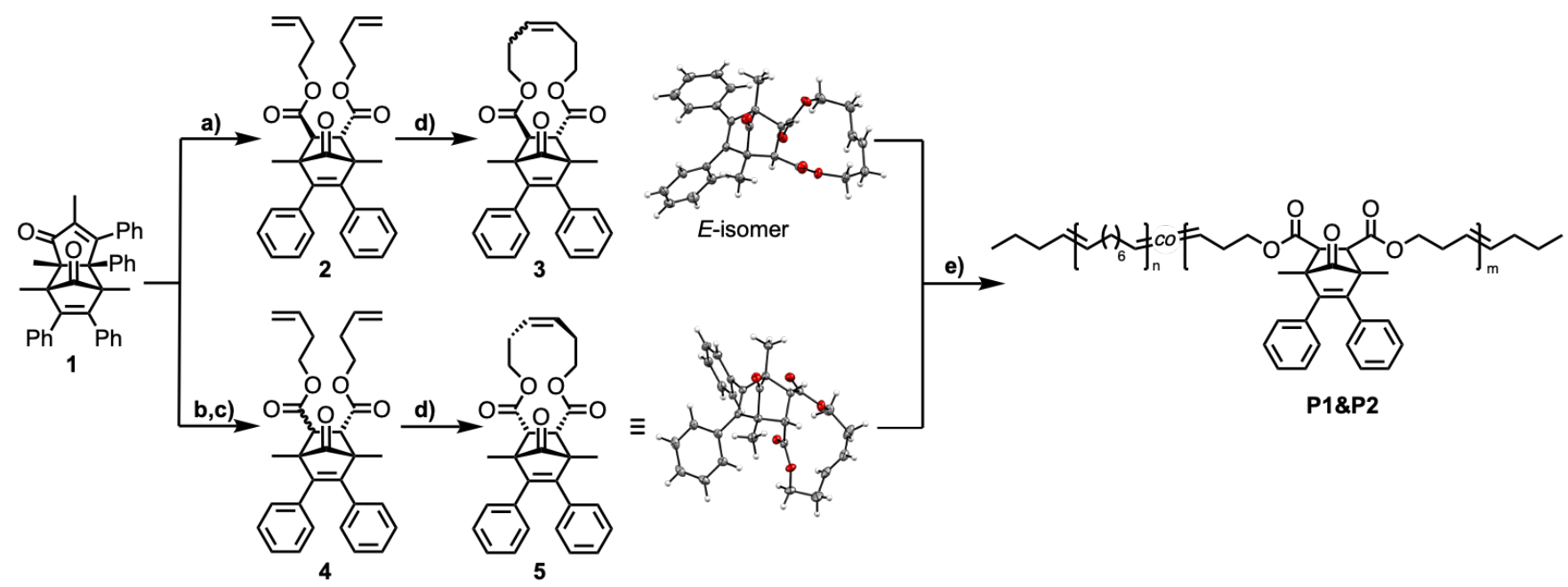

a) (3E)-di(but-3-en-1-yl) fumarate (2 equiv), reflux in toluene, $12 \mathrm{~h}(76 \%)$; b) maleic acid (2 equiv), toluene, reflux, $12 \mathrm{~h}$; c) 3-buten-1-ol (3 equiv), EDC (2.2 equiv), DMAP ( 0.1 equiv) THF, rt, 18 h (52\% over 2 steps); d) second generation Grubbs catalyst (0.05 equiv), DCM $(5 \mathrm{mM})$, reflux, $12 \mathrm{~h}(\mathbf{5}$ was isolated from mixture with $44 \%$ yield; 3 was obtained as E/Z mixture with 57\% yield); e) Polymerizations performed in $\mathrm{CHCl}_{3}$ at $60{ }^{\circ} \mathrm{C}$ for $20 \mathrm{~h}$ at $[\mathrm{NEO}]:[\mathrm{COE}]=1: 1$; [olefin $]_{0} /[\mathrm{G} 2]_{0}=4000$; [olefin $]_{0}=1.5 \mathrm{M}$.

Ring opening metathesis polymerization (ROMP) was chosen as our polymerization strategy for the incorporation of NEO into a MMP system. As described in previous reports, mechanophores with different isomeric configurations lead to unique products and exhibit large difference in activation percentages $(\Phi) .^{24-26}$ Thus, we individually designed and prepared cis- and trans-NEO containing isomers (Scheme 2). Starting from cyclopentadienone dimer 1, Diels-Alder cycloreversion/cycloaddition in the presence of a fumarate derivative followed by ring-closing metathesis (RCM) afforded macrocycle $3(E: Z=9: 1)$ in $43 \%$ yield. Following a similar strategy but using maleic acid in place of the fumarate derivative, 5 was obtained in $23 \%$ yield over 3 steps. Surprisingly, epimerization was observed during esterification leading to a mixture of cis- and trans- product (cis: trans $=5: 1$ ). Following the RCM reaction, macrocycle $\mathbf{5}$ was isolated (confirmed by single crystal X-ray diffraction) from other diastereomers in moderate yield (44\%). Subsequent ROMP of 3 or 5 with comonomer $(Z)$-cyclooctene $(\mathrm{COE})$ and chain transfer agent $(Z)$-oct-4-ene produced $\mathbf{P 1}$ and $\mathbf{P 2}$, respectively, with molecular weights $\left(M_{\mathrm{n}}\right)$ ranging from 6.2 to $158.8 \mathrm{kDa}$ and NEO incorporations of 44.1-52.6 mol\%.

The mechanochemical reactivity of $\mathbf{P 2}\left(M_{\mathrm{n}}=158.8 \mathrm{kDa}\right)$ was evaluated in dilute THF solutions using pulsed ultrasonication ( $1 \mathrm{~s}$ on $/ 1 \mathrm{~s}$ off, $\left.-10{ }^{\circ} \mathrm{C}, 20 \mathrm{kHz}, 8.8 \mathrm{~W} / \mathrm{cm}^{2}\right)$. After 240 min of sonication, ${ }^{1} \mathrm{H}$ NMR of the resulting material SP2 showed the appearance of six new resonance peaks at $\delta=$ $6.9,5.8,5.6,4.3,2.4$, and $2.2 \mathrm{ppm}$ with a concomitant decrease of all corresponding NEO resonances (Figure 1). The microstructure of SP2 was determined via 2D NMR analysis (Figure S10-12) and was consistent with the formation of a single isomer, as evidenced by the two sharp singlet resonances around $\delta=5.9$ and $2.2 \mathrm{ppm}$. While multiple isomers are conceivable based on the hypothesized diradical intermediate and its presumed isomerization pathways, ${ }^{24,25,27}$ formation of the sole $(E, Z, E)$ isomer was confirmed from ROESY and ${ }^{13} \mathrm{C}$ gated decoupling experiments (Figure S14-17). From peak assignments, it was determined that $58 \%$ of the NEO mechanophores were activated after $240 \mathrm{~min}$ of ultrasonication based on integration in ${ }^{1} \mathrm{H}$ NMR (Figure S7), which is in good agreement with quantitative ${ }^{13} \mathrm{C}$ NMR analysis (Figure S9). Low molecular weight $\mathbf{P 2}\left(M_{\mathrm{n}}=6.2 \mathrm{kDa}\right)$ showed no activation under the same sonication conditions, indicating the mechanical nature of this transformation (Figure S13).

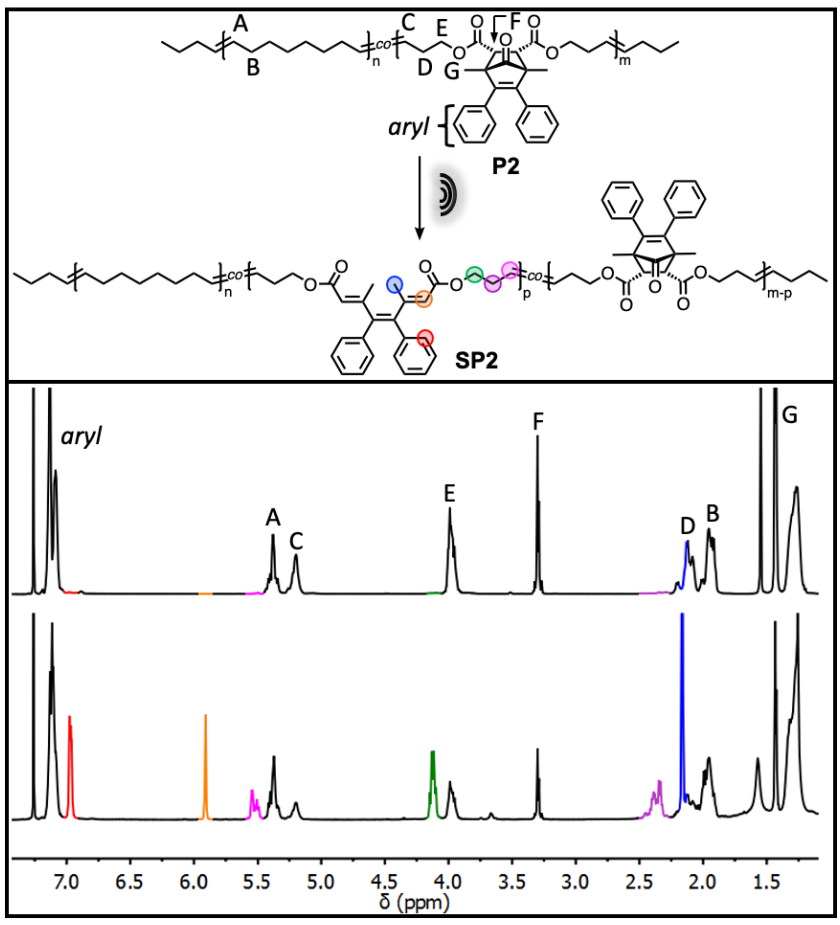

Figure 1: Stacked ${ }^{1} \mathrm{H}$ NMR transformation of $\mathbf{P 2}$ to $\mathbf{S P 2}$ in $\mathrm{CDCl}_{3}$ upon sonication. NMR assignments of resonances in SP2 are color coded in the lower spectrum. 

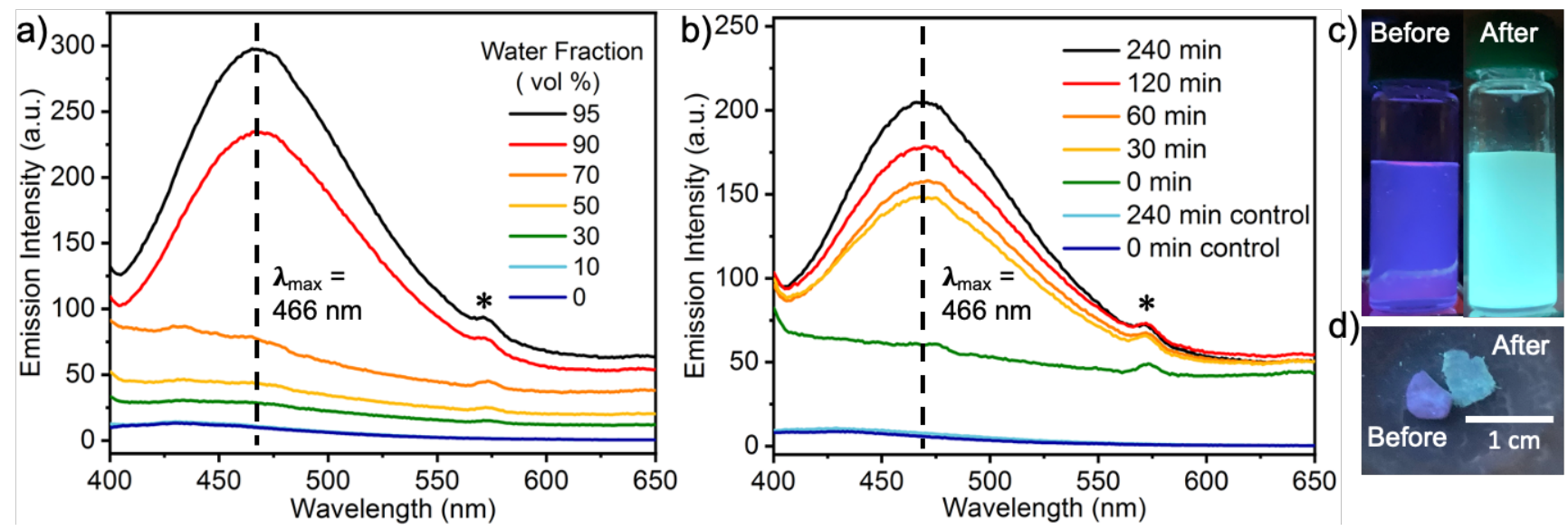

Figure 2: (a) Fluorescence spectra of SP2 in water/THF mixtures at different water fractions, $f_{w},\left(\lambda_{\mathrm{ex}}=350 \mathrm{~nm}\right)$. (b) Fluorescence spectra change during the sonication of $\mathbf{P} 2\left(M_{\mathrm{n}}=158.8 \mathrm{kDa}\right.$, polymer suspension was prepared in THF-water mixture with $f_{w}=90 \%$ at $0.05 \mathrm{mg} / \mathrm{mL}$, $\lambda_{\mathrm{ex}}=350 \mathrm{~nm}$ ). Control experiments were done using pure THF solution of $\mathbf{P 2}$ at $0.05 \mathrm{mg} / \mathrm{mL}$. (c) Photograph of polymer suspension before and after ultrasonication under $365 \mathrm{~nm}$ UV. Purple color was from the scattering light of the UV-lamp. (d) Solid-state mechanoactivation of P2. Photographs were taken under $365 \mathrm{~nm}$ UV irradiation. The emission peak labeled * originated from light-scattering efftects.
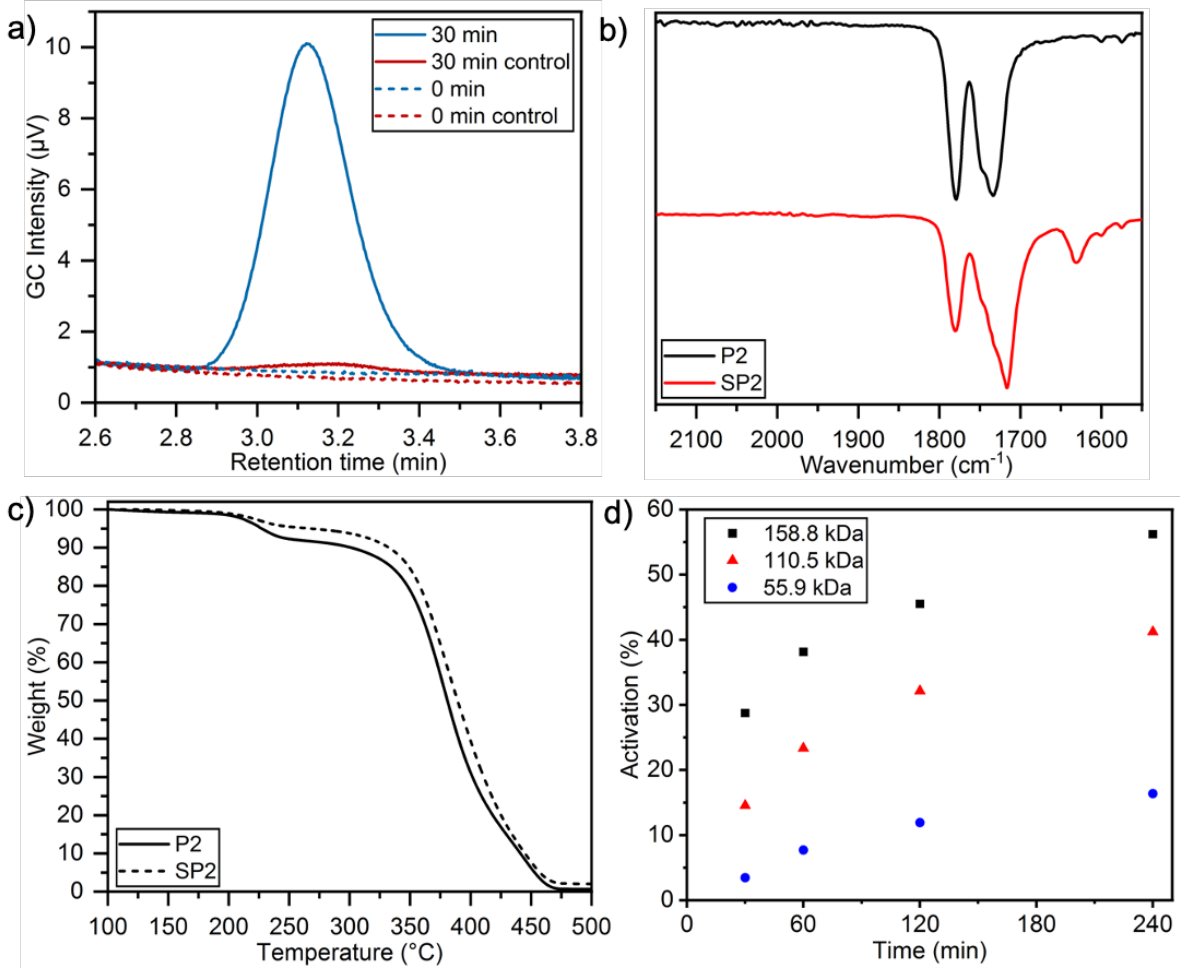

Figure 3: a) CO detection of $\mathbf{P 2}\left(M_{\mathrm{n}}=129.7 \mathrm{kDa}\right)$ and control polymer $\left(M_{\mathrm{n}}=6.2 \mathrm{kDa}\right)$ upon sonication using GC-TCD. b) IR spectra of $\mathbf{P 2}$ and $\mathbf{S P 2}(\Phi=58 \%)$. c) TGA analysis of $\mathbf{P 2}$ and SP2. d) Activation $\%(\Phi)$ of $\mathbf{P 2}$ with different $M_{\mathrm{n}}$ upon sonication. $\Phi$ was determined from the average of two trials.

Significantly lower mechanochemical activation $(\Phi=$ $12 \%)$ was observed for P1 of a similar molecular weight $\left(M_{\mathrm{n}}\right.$ $=143.7 \mathrm{kDa}, 46.8 \%$ NEO incorporation) after $240 \mathrm{~min}$ of sonication. While the main product obtained matched with that of $\mathbf{P 2}$, two smaller resonances appeared in the conjugated olefin region around $\delta=5.9 \mathrm{ppm}$, indicating the generation of other stereoisomers (Figure S18). Due to the overall low $\Phi$, these minor products were unable to be properly identified. Studies to determine the structure of these isomers as well as the origin of stereoselectivity and mechanosensitivity between the cis- and trans-NEO are ongoing.

Based on the determined structure of SP2, we reasoned by analogy to tetraphenylethene (TPE), one of the most common
AIE luminogens, that the diphenylethene motif in the macromolecular product exhibits similar photophysical properties. ${ }^{28}$ Different from typical aromatic luminophores that suffer from aggregation-caused quenching (ACQ) effects, AIE luminogens show dramatically enhanced emission profiles in the aggregated state. ${ }^{29}$ To our delight, under 365 nm UV irradiation, SP2 showed cyan fluorescence when aggregated in THF-water mixtures (Figure 2c). Comparatively, in pure THF solutions, minimal emissions were observed (Figure S25). To gain a better understanding of the photoluminescence property of SP2, the water fraction $\left(f_{\mathrm{w}}, \mathrm{vol} \%\right.$ water $)$ in these THF-water suspensions were varied. Rising of the baseline and tailing of the spectra were observed 
in the emission spectrum when increasing $f_{\mathrm{w}}$ from 0 to $70 \%$ due to the light-scattering effect of the formed nanoaggregates (Figure 2a). ${ }^{30}$ Maximum emission intensities were observed at $f_{\mathrm{w}}=95 \%$ with a maximum emission wavelength $\left(\lambda_{\max }\right)$ of $466 \mathrm{~nm}$. Aliquots from sonication experiments showed a continuous increase of emission when monitored over 240 min, indicating an accumulation of activated cis-NEO with time (Figure 2b). Fluorescence of SP2 was also measured at different concentrations and in the solid state, giving a similar $\lambda_{\max }$ (Figure S22). Solid state activation of $\mathbf{P 2}$ was also achieved by compression and shear of $\mathbf{P 2}\left(M_{\mathrm{n}}=120.0 \mathrm{kDa}\right)$ in a mortar by a pestle for 2 minutes and showed a similar cyan emission upon $365 \mathrm{~nm}$ UV irradiation (Figure 2d).

To confirm the release of $\mathrm{CO}$ from P2, gas chromatography (GC), infrared spectroscopy (IR) and thermal gravimetric analysis (TGA) were conducted (Figure 3). A GC equipped with a thermal conductivity detector (TCD) was first injected with a CO standard, as shown in Figure S26, and the retention time $\left(t_{R}\right)$ of CO was determined to be around $3.1 \mathrm{~min}$. After sonication of $\mathbf{P 2}\left(M_{\mathrm{n}}=129.7 \mathrm{kDa}\right)$ for $30 \mathrm{~min}$, an aliquot of the headspace was injected and showed the appearance of a peak with $t_{R}=3.1 \mathrm{~min}$, confirming the release of CO. Contrary, negligible $\mathrm{CO}$ was detected when low molecular weight $\mathbf{P 2}\left(M_{\mathrm{n}}=6.2 \mathrm{kDa}\right)$ was sonicated. Infrared (IR) spectroscopy analysis of SP2 vs P2 revealed a new band $\left(1631 \mathrm{~cm}^{-1}\right)$ and a small shift of the ester carbonyl band (from 1734 to $1717 \mathrm{~cm}^{-1}$ ) due to the generated conjugated alkenes as well as the unsaturated esters. Reduction of the bridge carbonyl stretching band $\left(1779 \mathrm{~cm}^{-1}\right)^{22}$ intensity after $240 \mathrm{~min}$ of sonication further validated the $\mathrm{CO}$ release. Lastly, differences in the weight loss between P2 and SP2 (6.8 and $3.6 \mathrm{wt} \%$, respectively) at the first onset of degradation $\left(T_{\mathrm{D}}=\right.$ $206{ }^{\circ} \mathrm{C}$ ), were in relatively good agreement with predicted values (4.7 and $2.9 \%$, respectively) for the mass loss of CO at $43.2 \mathrm{~mol} \%$ incorporation and $\Phi=38 \%$.

As the ability to control the amount of $\mathrm{CO}$ released in a tunable fashion is an important characteristic of CO-RMs, various molecular weight $\mathbf{P 2}$ were synthesized and the kinetics of activation were investigated. Sonication experiments were monitored by ${ }^{1} \mathrm{H}$ NMR and size-exclusion chromatography (SEC) analysis (Table S3) and showed an increase of $\Phi$ from $16 \%$ to $58 \%$ over the molecular weight range after $240 \mathrm{~min}$ (Figure 3d). This molecular weight dependent activation profile is in good agreement with other MMPs $^{31,32}$ and provides further proof of the mechanical nature of the mechanophore. SEC analysis showed a continuous decrease in molecular weight during sonication, indicating the competition between NEO activation and random backbone scission (Figure S29). For P2 of $55.9 \mathrm{kDa}, 110.5 \mathrm{kDa}$, and $158.8 \mathrm{kDa}$, it was determined that about 19,83 , and $154 \mathrm{CO}$ molecules are released on average per chain, respectively (See SI for more details).

In summary, we have demonstrated a new non-scissile MMP system that releases $\mathrm{CO}$ with turn-on AIE. A triene motif was generated upon mechanical force from a NEO scaffold as a distinctive product that has never been accessed before under other stimuli (heat, light, etc.). In addition, the NEO mechanophore represents the first example of mechanically induced AIE via covalent polymer mechanochemistry. We foresee that the NEO mechanophore will not only open exciting biological and biomedical opportunities, but also guide the design of novel forceresponsive AIE luminogens for damage detection and bioimaging applications.

\section{ASSOCIATED CONTENT}

\section{Supporting Information}

The Supporting Information is available free of charge on the ACS Publications website.

Synthesis and characterization of compounds (PDF)

Crystallographic data for compound $\mathbf{3}$ ( $E$-isomer) and $\mathbf{5}$ (CIF)

\section{AUTHOR INFORMATION}

\section{Corresponding Author}

* Jeffrey S. Moore - Beckman Institute for Advanced Science and Technology, University of Illinois at Urbana-Champaign, Urbana, Illinois 61801, United States; Department of Chemistry, University of Illinois at Urbana-Champaign, Urbana, Illinois 61801, United States

Email: jsmoore@illinois.edu

\section{Author Contributions}

\#Y.S and W.J.N contributed equally.

Notes

The authors declare no competing financial interest.

\section{ACKNOWLEDGMENT}

This research is financially supported by the Center for the Chemistry of Molecularly Optimized Networks (MONET), a National Science Foundation (NSF) Center for Chemical Innovation (CHE-21-16298). The authors thank Toby Woods for collecting crystal data, Dorothy Loudermilk for graphics assistance, Enrique Contreras and Professor Prashant Jain for the assistance with GC-TCD experiments. TGA and DSC experiments were carried out in the Materials Research Laboratory Central Research Facilities, University of Illinois.

\section{REFERENCES}

(1) Katsnelson, A. The Good Side of Carbon Monoxide. ACS Cent. Sci. 2019, 5, 1632-1635.

(2) Motterlini, R.; Otterbein, L. E. The Therapeutic Potential of Carbon Monoxide. Nat. Rev. Drug. Discov. 2010, 9, 728-743.

(3) Moore, B. A.; Overhaus, M.; Whitcomb, J.; Ifedigbo, E.; Choi, A. M. K.; Otterbein, L. E.; Bauer, A. J. Brief Inhalation of Low-Dose Carbon Monoxide Protects Rodents and Swine from Postoperative Ileus. Crit. Care Med. 2005, 33, 1317-1326.

(4) Nobre, L. S.; Seixas, J. D.; Romão, C. C.; Saraiva, L. M. Antimicrobial Action of Carbon Monoxide-Releasing Compounds. Antimicrob. Agents Chemother. 2007, 51, 43034307.

(5) Otterbein, L. E.; Bach, F. H.; Alam, J.; Soares, M.; Lu, H. T.; Wysk, M.; Davis, R. J.; Flavell, R. A.; Choi, A. M. K. Carbon Monoxide Has Anti-Inflammatory Effects Involving the Mitogen- Activated Protein Kinase Pathway. Nat. Med. 2000, 6, 422-428.

(6) Wegiel, B.; Gallo, D.; Csizmadia, E.; Harris, C.; Belcher, J.; Vercellotti, G. M.; Penacho, N.; Seth, P.; Sukhatme, V.; Ahmed, A.; Pandolfi, P. P.; Helczynski, L.; Bjartell, A.; Persson, J. L.; Otterbein, L. E. Carbon Monoxide Expedites Metabolic Exhaustion to Inhibit Tumor Growth. Cancer Res. 2013, 73, 7009-7021. 
(7) Yan, H.; Du, J.; Zhu, S.; Nie, G.; Zhang, H.; Gu, Z.; Zhao, Y. Emerging Delivery Strategies of Carbon Monoxide for Therapeutic Applications: From CO Gas to CO Releasing Nanomaterials. Small 2019, 15, 1904382.

(8) Palao, E.; Slanina, T.; Muchová, L.; Šolomek, T.; Vítek, L.; Klán, P. Transition-Metal-Free CO-Releasing BODIPY Derivatives Activatable by Visible to NIR Light as Promising Bioactive Molecules. J. Am. Chem. Soc. 2016, 138, 126-133.

(9) Pan, Z.; Zhang, J.; Ji, K.; Chittavong, V.; Ji, X.; Wang, B. Organic CO Prodrugs Activated by Endogenous ROS. Org. Lett. 2018, 20, 8-11.

(10) Ji, X.; Ji, K.; Chittavong, V.; Yu, B.; Pan, Z.; Wang, B. An Esterase-Activated Click and Release Approach to Metal-Free CO-Prodrugs Chem. Commun. 2017, 53, 82968299.

(11) Ling, K.; Men, F.; Wang, W. C.; Zhou, Y. Q.; Zhang, H. W.; Ye, D. W. Carbon Monoxide and Its Controlled Release: Therapeutic Application, Detection, and Development of Carbon Monoxide Releasing Molecules (CORMs). J. Med. Chem. 2018, 61, 2611-2635

(12) Hu, X.; Zeng, T.; Husic, C. C.; Robb, M. J. Mechanically Triggered Small Molecule Release from a Masked Furfuryl Carbonate. J. Am. Chem. Soc. 2019, 141, 15018-15023.

(13) Huo, S.; Zhao, P.; Shi, Z.; Zou, M.; Yang, X.; Warszawik, E.; Loznik, M.; Göstl, R.; Herrmann, A. Mechanochemical Bond Scission for the Activation of Drugs. Nat. Chem. 2021, 13, 131-139.

(14) Hu, X.; Zeng, T.; Husic, C. C.; Robb, M. J. Mechanically Triggered Release of Functionally Diverse Molecular Payloads from Masked 2-Furylcarbinol Derivatives. ACS Cent. Sci. 2021, 7, 1216-1224.

(15) Kim, G.; Lau, V. M.; Halmes, A. J.; Oelze, M. L.; Moore, J. S.; Li, K. C. High-Intensity Focused UltrasoundInduced Mechanochemical Transduction in Synthetic Elastomers. Proc. Natl. Acad. Sci. U. S. A. 2019, 116, 10214 10222.

(16) Bowser, B. H.; Craig, S. L. Empowering Mechanochemistry with Multi-Mechanophore Polymer Architectures. Polym. Chem. 2018, 9, 3583-3593.

(17) Larsen, M. B.; Boydston, A. J. "Flex-Activated" Mechanophores: Using Polymer Mechanochemistry to Direct Bond Bending Activation. J. Am. Chem. Soc. 2013, 135, 8189-8192.

(18) Shen, H.; Larsen, M. B.; Roessler, A. G.; Zimmerman, P. M.; Boydston, A. J. Mechanochemical Release of $N$-Heterocyclic Carbenes from Flex-Activated Mechanophores. Angew. Chem., Int. Ed. 2021, 60, 1355913563.

(19) Gossweiler, G. R.; Hewage, G. B.; Soriano, G.; Wang, Q.; Welshofer, G. W.; Zhao, X.; Craig, S. L. Mechanochemical Activation of Covalent Bonds in Polymers with Full and Repeatable Macroscopic Shape Recovery. ACS Macro Lett. 2014, 3, 216-219.

(20) Diesendruck, C. E.; Steinberg, B. D.; Sugai, N.; Silberstein, M. N.; Sottos, N. R.; White, S. R.; Braun, P. v.; Moore, J. S. Proton-Coupled Mechanochemical Transduction: A Mechanogenerated Acid. J. Am. Chem. Soc. 2012, 134, 12446-12449.

(21) Lin, Y.; Kouznetsova, T. B.; Craig, S. L. A Latent Mechanoacid for Time-Stamped Mechanochromism and Chemical Signaling in Polymeric Materials. J. Am. Chem. Soc. 2020, 142, 1, 99-103.
(22) Ogliaruso, M. A.; Romanelli, M. G.; Becker, E. I. Chemisty of Cyclopentadienenones. Chem. Rev. 1965, 65, 261-367.

(23) Kueh, J. T. B.; Stanley, N. J.; Hewitt, R. J.; Woods L. M.; Larsen, L.; Harrison, J. C.; Rennison, D.; Brimble, M. A.; Sammut, I. A.; Larsen, D. S. Norborn-2-En-7-Ones as Physiologically-Triggered Carbon Monoxide-Releasing Prodrugs. Chem. Sci. 2017, 8, 5454-5459.

(24) Liu, Y.; Holm, S.; Meisner, J.; Jia, Y.; Wu, Q.; Woods, T. J.; Martinez, T. J.; Moore, J. S. Flyby Reaction Trajectories: Chemical Dynamics under Extrinsic Force. Science 2021, 373, 208-212.

(25) Kean, Z. S.; Niu, Z.; Hewage, G. B.; Rheingold, A. L.; Craig, S. L. Stress-Responsive Polymers Containing Cyclobutane Core Mechanophores: Reactivity and Mechanistic Insights. J. Am. Chem. Soc. 2013, 135, 1359813604.

(26) Jung, S.; Yoon, H. J. Mechanical Force Induces Ylide-Free Cycloaddition of Nonscissible Aziridines. Angew. Chem., Int. Ed. 2020, 59, 4883-4887.

(27) Chen, Z.; Zhu, X.; Yang, J.; Mercer, J. A. M.; Burns, N. Z.; Martinez, T. J.; Xia, Y. The Cascade Unzipping of Ladderane Reveals Dynamic Effects in Mechanochemistry. Nat. Chem. 2020, 12, 302-309.

(28) Mei, J.; Leung, N. L. C.; Kwok, R. T. K.; Lam, J. W. Y; Tang, B. Z. Aggregation-Induced Emission: Together We Shine, United We Soar! Chem. Rev. 2015, 115, 11718-11940.

(29) Hong, Y.; Lam, J. W. Y.; Tang, B. Z. AggregationInduced Emission: Phenomenon, Mechanism and Applications. Chem. Commun., 2009, 4332-4353.

(30) Pramanik, S.; Bhalla, V.; Kumar, M Hexaphenylbenzene-Based Fluorescent Aggregates for Ratiometric Detection of Cyanide Ions at Nanomolar Level: Set-Reset Memorized Sequential Logic Device. ACS Appl. Mater. Interfaces 2014, 6, 5930-5939.

(31) Hsu, T. G.; Zhou, J.; Su, H. W.; Schrage, B. R.; Ziegler, C. J.; Wang, J. A Polymer with "Locked" Degradability: Superior Backbone Stability and Accessible Degradability Enabled by Mechanophore Installation. J. Am. Chem. Soc. 2020, 142, 2100-2104.

(32) Lenhardt, J. M.; Black Ramirez, A. L.; Lee, B.; Kouznetsova, T. B.; Craig, S. L. Mechanistic Insights into the Sonochemical Activation of Multimechanophore Cyclopropanated Polybutadiene Polymers. Macromolecules 2015, 48, 6396-6403. 
Table of Contents artwork

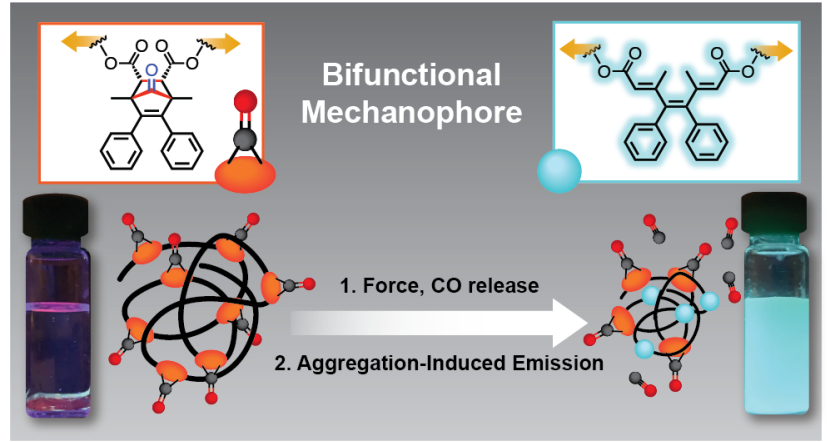




\section{Supporting Information}

\section{Mechanically Triggered Carbon Monoxide Release with Turn- on Aggregation-Induced Emission}

Yunyan Sun ${ }^{\#, \dagger}$, William J. Neary ${ }^{\#, \dagger}$, Zach P. Burke ${ }^{\dagger}$, Hai Qian ${ }^{\S}$, Lingyang Zhu ${ }^{\dagger}$, and Jeffrey S. Moore ${ }^{*, \dagger, \$}$

†Department of Chemistry, University of Illinois at Urbana-Champaign, Urbana, Illinois 61801, United States. ${ }^{\S}$ Beckman Institute for Advanced Science and Technology, University of Illinois at Urbana-Champaign, Urbana, Illinois 61801, United States.

\# These authors contributed equally

*Corresponding authors: jsmoore@illinois.edu

\section{Table of Content}

Materials and Characterization..................................................2

Synthetic Procedures.................................................................3

General Sonication Procedures....................................................

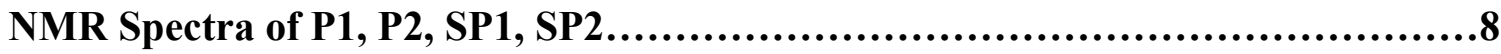

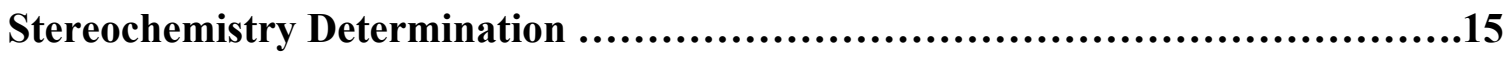

X-ray Crystals Structures.......................................................20

Photophysical Characterizations....................................................23

GC-TCD CO Detections..........................................................25

SEC Characterizations.............................................................26

DSC Analysis............................................................................27

Scission Cycle and Calculations..................................................27

NMR Spectra.........................................................................30

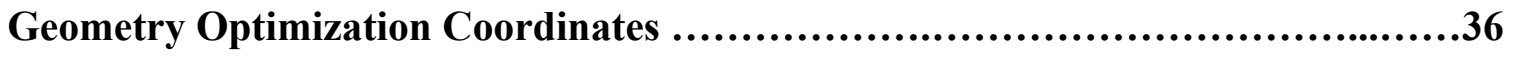

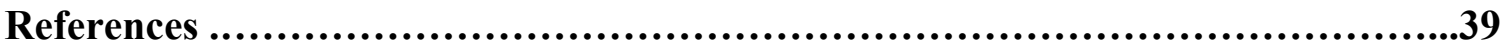




\section{Materials:}

Reagents from commercial sources were used without further purification unless otherwise noted. Anhydrous dichloromethane $\left(\mathrm{CH}_{2} \mathrm{Cl}_{2}\right)$, tetrahydrofuran (THF), triethylamine, and toluene were obtained from a solvent purification system equipped with activated alumina columns. Anhydrous chloroform $\left(\mathrm{CHCl}_{3}\right)$ was obtained by distillation over $\mathrm{P}_{2} \mathrm{O}_{5}$. Column chromatography was performed on Biotage Isolera using Silicycle SiliaSep HP flash cartridges. Deuterated solvents were purchased from Cambridge Isotope Laboratories, Inc. and used as received. TLC plates with fluorescent indicator F254 were used and visualized with UV lamps.

\section{Characterization:}

${ }^{1} \mathrm{H}-\mathrm{NMR}$ spectra were recorded using a Varian Inova $400 \mathrm{MHz}$ and $500 \mathrm{MHz}$ spectrometers. ${ }^{13} \mathrm{C}-\mathrm{NMR}$, and $2 \mathrm{D}$ spectra were recorded with a Bruker Avance III HD 500 $\mathrm{MHz}$ spectrometer equipped with a BBFO cryoprobe and are reported in parts per million $(\mathrm{ppm})$ relative to their respective solvent $\left(\left(\mathrm{CDCl}_{3}\right) \delta=7.26\right.$ or TMS. Hi-Res mass spectra were obtained on a Waters Synapt G2-Si ESI mass spectrometer. Size exclusion chromatography (SEC) was performed on an Agilent 1260 Infinity system equipped with an isocratic pump, degasser, autosampler, and a series of 4 Waters HR Styragel columns $\left(7.8 \times 300 \mathrm{~mm}, \mathrm{HR} 1, \mathrm{HR} 3, \mathrm{HR} 4\right.$, and HR5) in THF at $25^{\circ} \mathrm{C}$ and a flow rate of $1 \mathrm{~mL} \cdot \mathrm{min}^{-}$ 1 . The system is equipped with a triple detection system that includes an Agilent 1200 series G1362A Infinity Refractive Index Detector (RID), a Wyatt Viscostar II viscometer detector, and a Wyatt MiniDAWN Treos 3-angle light-scattering detector. Molecular weights and dispersities $(\bigoplus)$ were determined by a 12-point conventional column calibration with narrow dispersity polystyrene standards ranging from 980 to 1,013,000 Da. Absorption spectroscopy was performed using a UV-2501PC UV-Vis recording spectrophotometer (SHIMADZU). Emission spectroscopy was performed using a Fluoromax-4 fluorometer (Horiba). Thermal gravimetric analysis (TGA) was conducted on a TA Instruments Q50 Thermogravimetric Analysis under $\mathrm{N}_{2}$ at $10{ }^{\circ} \mathrm{C} \cdot \mathrm{min}^{-1}$. Differential scanning calorimetry (DSC) was conducted on a TA Instruments Discovery 250 at a ramp / cooling rate of $10^{\circ} \mathrm{C}$ - min $^{-1}$ under nitrogen in an aluminum hermetic DSC pan. Glass transition temperatures were taken from the second heating cycle. Ultrasound experiments were performed using a Vibra Cell 505 liquid processor equipped with a $0.5^{\prime \prime}$ diameter solid probe from Sonics and Materials. Suslick cells ${ }^{12}$ were fabricated by the School of Chemical Sciences Glass Shop at the University of Illinois. A Neslab CC 100 immersion cooler equipped with a Cryotrol temperature controller was used to maintain a constant- temperature bath for sonication experiments. Typical sonication experiments were performed using pulsed ultrasound ( $1.0 \mathrm{~s}$ on, $2.0 \mathrm{~s}$ off) at $20 \mathrm{kHz}$ under $\mathrm{N}_{2}$ with an output ultrasound intensity of $8.8 \mathrm{~W} / \mathrm{cm}^{2}$ at $-10{ }^{\circ} \mathrm{C}$. Ultrasonic intensity was calibrated using the method described by Berkowski et al. ${ }^{1}$ Gas chromatography $(\mathrm{GC})$ experiments were performed using Agilent $7820 \mathrm{~A}$ instrument equipped with a thermal conductivity detector and a $5 \AA$ molecular sieves (80-100 mesh) column with helium being used as the carrier gas. Geometry optimizations were performed in the Gaussian 09 software, ${ }^{2}$ using the B3LYP density functional theory (DFT) and the $6-31 \mathrm{G}^{*}$ basis set. 


\section{Synthetic Procedure:}<smiles>O=C(C(=O)c1ccccc1)c1ccccc1</smiles><smiles>CCC(=O)CC</smiles><smiles>CC1=C(c2ccccc2)C(c2ccccc2)=C(C)C1=O</smiles>

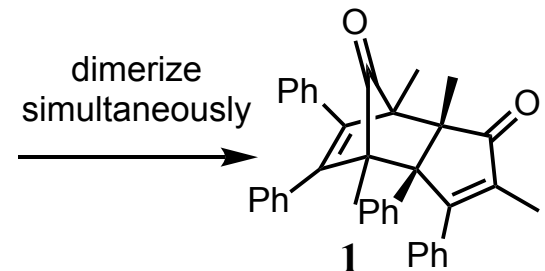

(1): The synthesis of compound 1 was performed using reported protocol. ${ }^{3}$

To a stirred solution of benzil (10.0 g, $47.6 \mathrm{mmol})$ and 3-pentanone $(4.08 \mathrm{~g}, 47.4 \mathrm{mmol})$ in isopropanol $(200 \mathrm{~mL})$, a solution of $\mathrm{KOH}(2.40 \mathrm{~g}, 42.7 \mathrm{mmol})$ dissolved in $100 \mathrm{~mL}$ of isopropanol was added and allowed to stir for $3 \mathrm{~h}$ at rt. The solution was concentrated, and the residue was diluted with EtOAc. The organic layer was washed with water, brine, dried over anhydrous $\mathrm{Na}_{2} \mathrm{SO}_{4}$, filtered, and concentrated under vacuum. To the crude product, $40 \mathrm{~mL}$ of acetic anhydride and $0.5 \mathrm{~mL}$ of concentrated $\mathrm{H}_{2} \mathrm{SO}_{4}$ were added to the flask and allowed to stir for $5 \mathrm{~h}$ at $\mathrm{rt}$. The solution was then added to water $(450 \mathrm{~mL})$ with stirring and the precipitate was collected, washed with water, and dried in vacuum to afford the dimer of $1(10.1 \mathrm{~g}, 81 \%)$ as a grey powder. 1: ${ }^{1} \mathrm{H} \mathrm{NMR}\left(500 \mathrm{MHz}, \mathrm{CDCl}_{3}\right) \delta 7.57-7.30$ $(\mathrm{m}, 2 \mathrm{H}), 7.25-7.18(\mathrm{~m}, 4 \mathrm{H}), 7.14-7.08(\mathrm{~m}, 4 \mathrm{H}), 7.06(\mathrm{t}, \mathrm{J}=7.3 \mathrm{~Hz}, 1 \mathrm{H}), 6.96(\mathrm{td}, \mathrm{J}=$ 8.1, 6.2 Hz, 5H), $6.90(\mathrm{dd}, \mathrm{J}=6.7,2.8 \mathrm{~Hz}, 2 \mathrm{H}), 6.74-6.63(\mathrm{~m}, 2 \mathrm{H}), 2.25(\mathrm{~s}, 3 \mathrm{H}), 1.64(\mathrm{~s}$, $3 \mathrm{H}), 1.25(\mathrm{~s}, 3 \mathrm{H}), 0.58(\mathrm{~s}, 3 \mathrm{H}),{ }^{13} \mathrm{C}$ NMR $\left(126 \mathrm{MHz}, \mathrm{CDCl}_{3}\right) \delta$ 209.60, 203.30, 166.06, $144.48,143.33$, 142.98, 140.23, 134.21, 134.13, 133.51, 131.97, 130.94, 130.27, 129.46, 128.02 , 127.43, 127.36, 127.15, 127.04, 127.00, 66.86, 61.15, 59.84, 58.62, 18.18, 12.53, 12.43, 9.95. HRMS-ESI $(\mathrm{m} / \mathrm{z})$ : found $[\mathrm{M}+\mathrm{H}]^{+}$for $\mathrm{C}_{38} \mathrm{H}_{33} \mathrm{O}_{2} 521.2457$ (calcd. 521.2481)

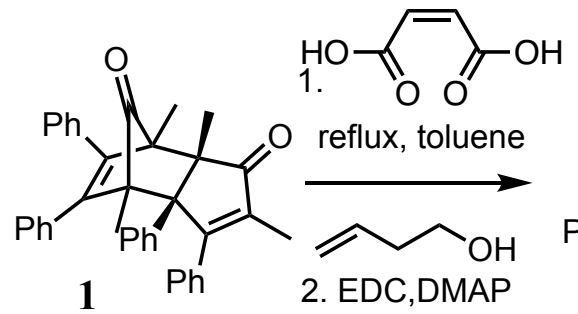

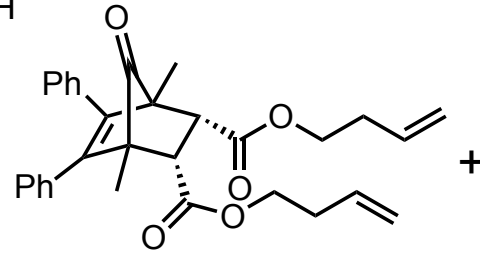

2

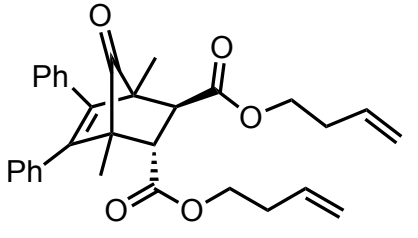

5

di(but-3-en-1-yl)-1,4-dimethyl-7-oxo-5,6-diphenylbicyclo [2.2.1] hept-5-ene-2,3dicarboxylate (2): To an oven-dried round bottom flask equipped with a stir bar, dimer 1 ( $8.06 \mathrm{~g}, 0.16 \mathrm{mmol}, 1$ equiv) and maleic acid (3.61 g, $0.31 \mathrm{mmol}, 2$ equiv) were refluxed in toluene $(70 \mathrm{~mL})$ under nitrogen for $12 \mathrm{~h}$. After cooling to $\mathrm{rt}$, the mixture was concentrated and the residue $(10.0 \mathrm{~g}, 86 \%)$ was used without purification. The crude reaction mixture (5.0 g, $10.3 \mathrm{mmol}, 1$ equiv) and 4-dimethylaminopyridine (DMAP) $(0.13$ $\mathrm{g}, 1.0 \mathrm{mmol}, 0.1$ equiv) were then dissolved in anhydrous THF $(50 \mathrm{~mL})$ and cooled to $0{ }^{\circ} \mathrm{C}$ before EDC ( $4.4 \mathrm{~g}, 22.7 \mathrm{mmol}, 2.2$ equiv) was added. The mixture was allowed to stir for $10 \mathrm{~min}$ and at this time, 3-buten-1-ol (2.2 g, $31.0 \mathrm{mmol}, 3$ equiv) was injected and the reaction mixture was allowed to stir at rt overnight. After removal of volatiles, the reaction mixture was diluted with EtOAc $(200 \mathrm{~mL})$ and subsequently washed with water $(200 \mathrm{~mL})$, $0.1 \mathrm{M} \mathrm{HCl}(200 \mathrm{~mL})$, water $(200 \mathrm{~mL})$, saturated $\mathrm{NaHCO}_{3}$ aqueous solution $(200 \mathrm{~mL})$, and brine $(200 \mathrm{~mL})$. The material was dried over $\mathrm{Na}_{2} \mathrm{SO}_{4}$, filtered, and concentrated in vacuo. 
The crude product was purified by column chromatography ( $15 \%$ ethyl acetate in hexanes) to afford 2 as a yellow solid ( $2.6 \mathrm{~g}, 52 \%)$. Undesired isomerization was observed during esterification to afford an inseparable mixture of $c i$ and trans isomer (cis/trans $=5: 1) .2$ (cis isomer): ${ }^{1} \mathrm{H}$ NMR $\left(500 \mathrm{MHz}, \mathrm{CDCl}_{3}\right) \delta 7.18-7.08(\mathrm{~m}, 10 \mathrm{H}), 5.64$ (ddt, $\mathrm{J}=16.7,9.7$, $6.7 \mathrm{~Hz}, 2 \mathrm{H}), 5.04-4.97(\mathrm{~m}, 4 \mathrm{H}), 4.06(\mathrm{q}, \mathrm{J}=6.7 \mathrm{~Hz}, 4 \mathrm{H}), 3.32(\mathrm{~s}, 2 \mathrm{H}), 2.25-2.18$ (m, $4 \mathrm{H}), 1.45(\mathrm{~s}, 6 \mathrm{H}) .{ }^{13} \mathrm{C} \mathrm{NMR}\left(126 \mathrm{MHz}, \mathrm{CDCl}_{3}\right) \delta 200.04,170.28,141.74,134.69,133.95$, $130.30,127.72,127.22,117.32,64.13,56.66,51.12,32.78,12.01$. HRMS-ESI $(m / z)$ : found $[\mathrm{M}+\mathrm{H}]^{+}$for $\mathrm{C}_{31} \mathrm{H}_{33} \mathrm{O}_{5} 485.2312$ (calcd. 485.2328)

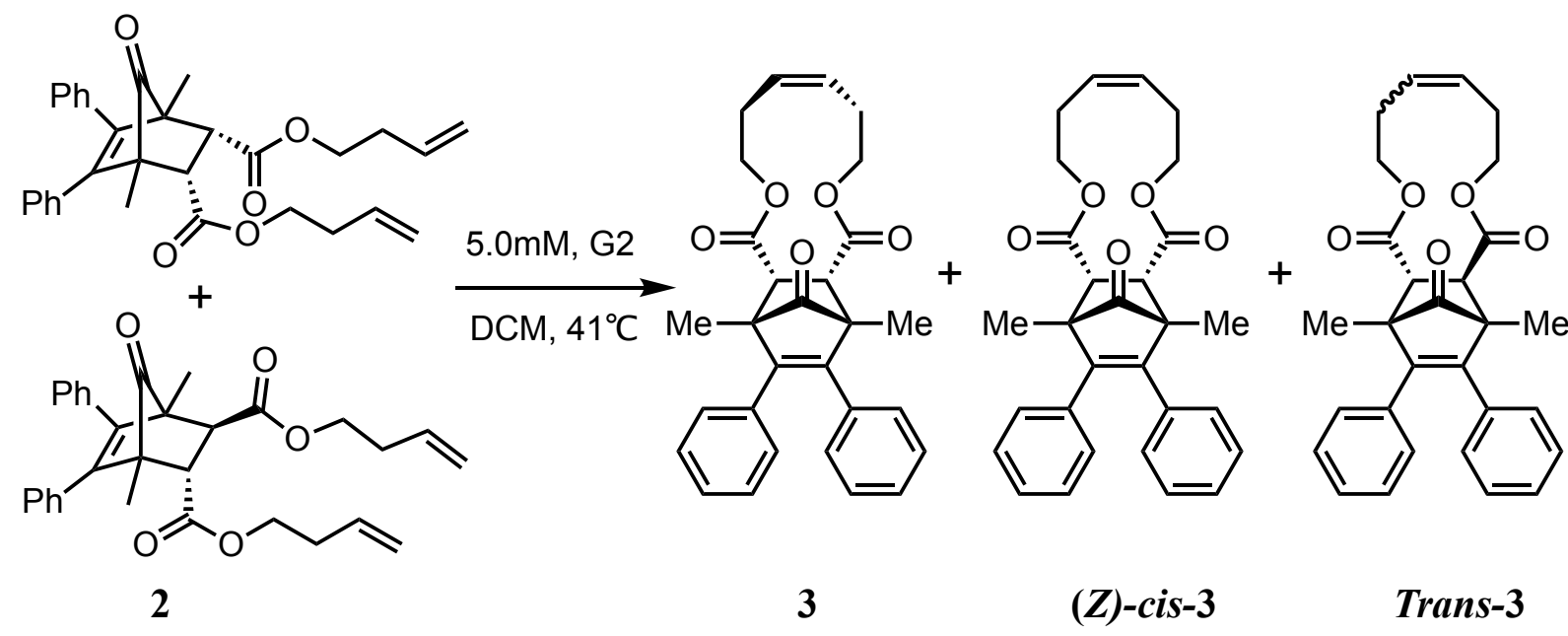

(3): Compound 2 (mixture of cis and trans isomers, $1.0 \mathrm{~g}, 2.0 \mathrm{mmol}$ ) was dissolved in anhydrous $\mathrm{CH}_{2} \mathrm{Cl}_{2}(400 \mathrm{~mL}, 5.0 \mathrm{mM})$ and the solution was sparged with argon for $15 \mathrm{~min}$. Second generation Grubbs catalyst ( $44.5 \mathrm{mg}, 0.05 \mathrm{mmol}, 0.025$ equiv) was then added under a positive argon flow and the solution was refluxed for $12 \mathrm{~h}$. At this time, the solution was concentrated and purified by column chromatography (12\% ethyl acetate in hexanes) to afford $\mathbf{3}$ as a white solid. Further purification of $\mathbf{3}$ was done by recrystallization in $50 \%$ DCM in hexanes to remove residual (Z)-cis-3 and trans-3 macrocycles and afforded colorless crystals of $\mathbf{3}(0.41 \mathrm{~g}, 44 \%)$. The structure of $\mathbf{3}$ was confirmed by single crystal Xray diffraction. 3: ${ }^{1} \mathrm{H}$ NMR $\left(400 \mathrm{MHz}, \mathrm{CDCl}_{3}\right) \delta 7.13(\mathrm{q}, J=4.3,3.4 \mathrm{~Hz}, 6 \mathrm{H}), 7.09-7.03$ $(\mathrm{m}, 4 \mathrm{H}), 5.49(\mathrm{~s}, 2 \mathrm{H}), 4.54-4.41(\mathrm{~m}, 2 \mathrm{H}), 3.89(\mathrm{~d}, J=10.2 \mathrm{~Hz}, 2 \mathrm{H}), 3.29(\mathrm{~s}, 2 \mathrm{H}), 2.29(\mathrm{~s}$, $4 \mathrm{H}), 1.41(\mathrm{~s}, 6 \mathrm{H}) .{ }^{13} \mathrm{C} \mathrm{NMR}\left(126 \mathrm{MHz}, \mathrm{CDCl}_{3}\right) \delta 199.66,169.86,141.50,134.83,130.08$, $128.59,127.79,127.26,64.21,56.96,51.89,27.14,11.83$. HRMS-ESI $(\mathrm{m} / \mathrm{z})$ : found $[\mathrm{M}+\mathrm{H}]^{+}$for $\mathrm{C}_{29} \mathrm{H}_{29} \mathrm{O}_{5} 457.2008$ (calcd. 457.2015) 


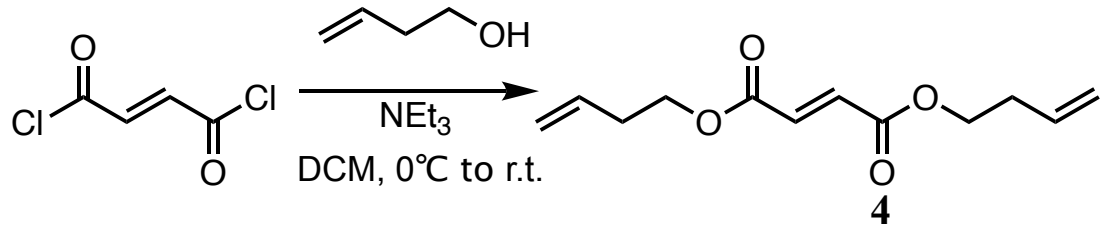

Di(but-3-en-1-yl) fumarate (4): To a stirred solution of fumaryl chloride $(1.0 \mathrm{~g}, 6.5 \mathrm{mmol}$, 1 equiv) in anhydrous $\mathrm{CH}_{2} \mathrm{Cl}_{2}$ (18 mL), 3-buten-1-ol (1.4 g, $19.6 \mathrm{mmol}, 3.0$ equiv) was added under a nitrogen atmosphere. Anhydrous triethylamine ( $1.3 \mathrm{~g}, 13.1 \mathrm{mmol}, 2$ equiv) was then added dropwise at $0{ }^{\circ} \mathrm{C}$. The reaction mixture was then allowed to warm to $\mathrm{rt}$ and was stirred overnight. After completion, the reaction mixture was diluted with DCM (100 $\mathrm{mL})$ and the organic layer was washed with saturated $\mathrm{NH}_{4} \mathrm{Cl}(100 \mathrm{~mL})$, water $(100 \mathrm{~mL})$, brine $(100 \mathrm{~mL})$, dried over $\mathrm{Na}_{2} \mathrm{SO}_{4}$, filtered, and concentrated in vacuo. The crude product was further purified by column chromatography ( $10 \%$ ethyl acetate in hexanes) to afford 4 as colorless oil $(1.4 \mathrm{~g}, 96 \%) .{ }^{1} \mathrm{H}$ NMR $\left(500 \mathrm{MHz}, \mathrm{CDCl}_{3}\right) \delta 6.84(\mathrm{~d}, J=2.1 \mathrm{~Hz}, 2 \mathrm{H}), 5.78$ (ddt, $J=17.1,10.2,6.7 \mathrm{~Hz}, 2 \mathrm{H}), 5.18-5.06(\mathrm{~m}, 4 \mathrm{H}), 4.25(\mathrm{td}, J=6.7,2.2 \mathrm{~Hz}, 4 \mathrm{H}), 2.43$ (qt, $J=6.7,1.4 \mathrm{~Hz}, 4 \mathrm{H}) .{ }^{13} \mathrm{C}$ NMR $\left(126 \mathrm{MHz}, \mathrm{CDCl}_{3}\right) \delta 165.03,133.71,133.70,117.70$, 64.47, 33.03. HRMS-ESI $(\mathrm{m} / \mathrm{z})$ : found $[\mathrm{M}+\mathrm{H}]^{+}$for $\mathrm{C}_{12} \mathrm{H}_{17} \mathrm{O}_{4} 225.1124$ (calcd. 225.1127)

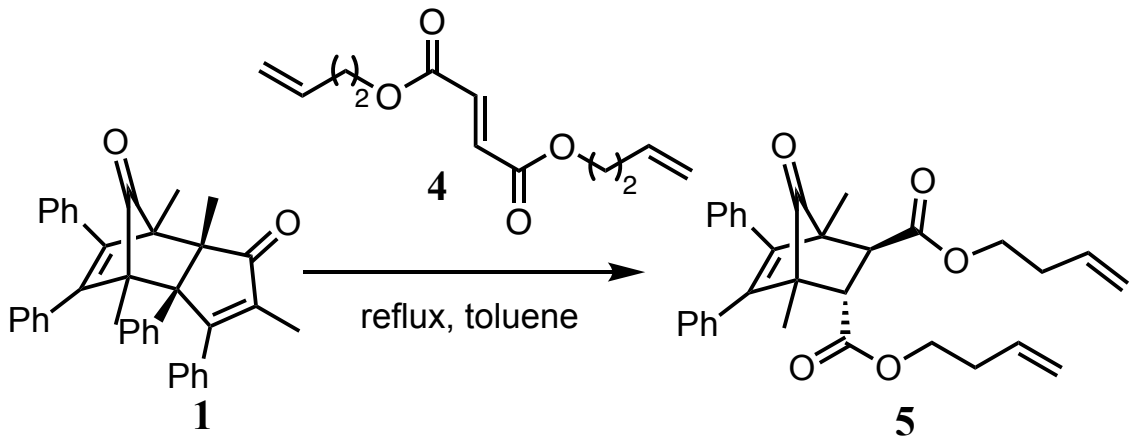

Trans-di(but-3-en-1-yl)-1,4-dimethyl-7-oxo-5,6-diphenylbicyclo [2.2.1]hept-5-ene2,3-dicarboxylate (5): To a stirred solution of dimer 1 (1.16 g, $2.2 \mathrm{mmol}, 1$ equiv) in toluene (10 mL), compound 4 (1.0 g, $4.5 \mathrm{mmol}, 2$ equiv) was added and refluxed under nitrogen for $12 \mathrm{~h}$. After cooling to $\mathrm{rt}$, the solvent was evaporated under vacuum and the crude product was purified by column chromatography (12\% ethyl acetate in hexanes) to afford 5 as white solid $(0.82 \mathrm{~g}, 76 \%) .5$ : ${ }^{1} \mathrm{H}$ NMR $\left(500 \mathrm{MHz}, \mathrm{CDCl}_{3}\right) \delta 7.23-7.18(\mathrm{~m}, 3 \mathrm{H})$, $7.15(\mathrm{tt}, J=5.1,2.5 \mathrm{~Hz}, 3 \mathrm{H}), 7.04(\mathrm{dt}, J=6.7,1.5 \mathrm{~Hz}, 2 \mathrm{H}), 6.93-6.86(\mathrm{~m}, 2 \mathrm{H}), 5.79$ (ddd, $J=17.2,10.3,1.2 \mathrm{~Hz}, 1 \mathrm{H}), 5.55-5.44(\mathrm{~m}, 1 \mathrm{H}), 5.19-5.07(\mathrm{~m}, 2 \mathrm{H}), 4.99-4.88(\mathrm{~m}, 2 \mathrm{H})$, $4.26-4.13(\mathrm{~m}, 2 \mathrm{H}), 4.01-3.85(\mathrm{~m}, 2 \mathrm{H}), 3.52(\mathrm{dd}, J=4.7,1.3 \mathrm{~Hz}, 1 \mathrm{H}), 3.30(\mathrm{dd}, J=4.9$, $1.3 \mathrm{~Hz}, 1 \mathrm{H}), 2.43(\mathrm{q}, J=6.8 \mathrm{~Hz}, 2 \mathrm{H}), 2.06(\mathrm{qd}, J=6.7,1.5 \mathrm{~Hz}, 2 \mathrm{H}), 1.57(\mathrm{~d}, J=1.4 \mathrm{~Hz}$, $3 \mathrm{H}), 1.22(\mathrm{~d}, J=1.3 \mathrm{~Hz}, 3 \mathrm{H}) .{ }^{13} \mathrm{C}$ NMR $\left(126 \mathrm{MHz}, \mathrm{CDCl}_{3}\right) \delta 201.60,172.23,171.41$, $143.50,140.88,133.79,133.77,133.64,129.64,129.26,128.24,127.99$, 127.74, 127.49, $117.72,117.42,64.56,64.51,56.42,55.97,51.62,50.22,33.10,32.66,12.38,9.71$. HRMS$\operatorname{ESI}(\mathrm{m} / \mathrm{z})$ : found $[\mathrm{M}+\mathrm{H}]^{+}$for $\mathrm{C}_{31} \mathrm{H}_{33} \mathrm{O}_{5} 485.2313$ (calcd. 485.2328) 


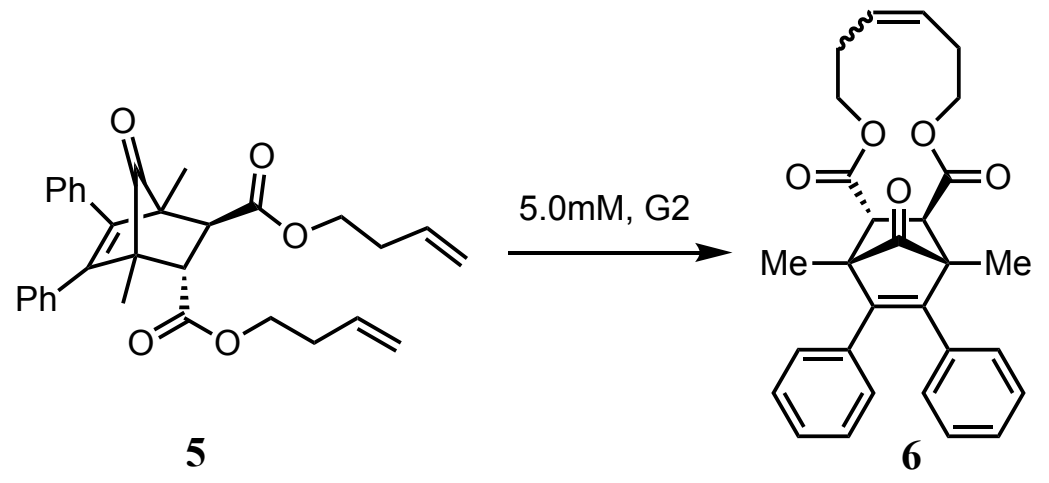

(6): Compound 5 (0.5 g, $1.0 \mathrm{mmol})$ was first dissolved in anhydrous DCM (90 mL, 5.0 $\mathrm{mM}$ ), and the solution sparged with argon for $15 \mathrm{~min}$. Second generation Grubbs catalyst ( $21 \mathrm{mg}, 0.026 \mathrm{mmol}, 0.025$ equiv) was then added under a positive argon atmosphere and was refluxed for $12 \mathrm{~h}$. After completion, the solution was concentrated and the crude product was purified by column chromatography (12\% ethyl acetate in hexanes) to afford 6 as a white solid $(0.26 \mathrm{~g}, 57 \%, E: Z=9: 1)$. The major product of $\mathbf{6}$ ( $E$ isomer) was confirmed by single crystal X-ray diffraction. 6: ${ }^{1} \mathrm{H}$ NMR $\left(500 \mathrm{MHz}, \mathrm{CDCl}_{3}\right) \delta 7.24-7.19$ $(\mathrm{m}, 3 \mathrm{H}), 7.18-7.13(\mathrm{~m}, 3 \mathrm{H}), 7.06(\mathrm{ddd}, J=10.0,5.5,2.4 \mathrm{~Hz}, 4 \mathrm{H}), 5.41-5.26(\mathrm{~m}, 2 \mathrm{H})$, 4.68 (ddd, $J=12.9,11.0,2.6 \mathrm{~Hz}, 1 \mathrm{H}), 4.58$ (td, $J=11.4,3.3 \mathrm{~Hz}, 1 \mathrm{H}), 3.96$ (ddd, $J=10.9$, 4.6, $2.2 \mathrm{~Hz}, 1 \mathrm{H}), 3.81(\mathrm{ddd}, J=11.0,4.5,2.1 \mathrm{~Hz}, 1 \mathrm{H}), 3.11(\mathrm{~d}, J=7.8 \mathrm{~Hz}, 1 \mathrm{H}), 3.01(\mathrm{~d}, J$ $=7.9 \mathrm{~Hz}, 1 \mathrm{H}), 2.34(\mathrm{ddt}, J=24.3,11.6,7.9 \mathrm{~Hz}, 4 \mathrm{H}), 1.38(\mathrm{~s}, 3 \mathrm{H}), 1.33(\mathrm{~s}, 3 \mathrm{H}) .{ }^{13} \mathrm{C} \mathrm{NMR}$ $\left(126 \mathrm{MHz}, \mathrm{CDCl}_{3}\right) \delta 201.00,172.40,172.16,143.50,142.28,134.34,133.72,130.10$, $130.06,129.73,129.70,128.30,128.27,127.92,127.88,127.69,127.39,62.79,62.67$, $56.20,54.39,53.76,52.91,33.46,33.30,11.45,9.20$. HRMS-ESI $(\mathrm{m} / \mathrm{z})$ : found $[\mathrm{M}+\mathrm{H}]^{+}$for $\mathrm{C}_{29} \mathrm{H}_{29} \mathrm{O}_{5} 457.2025$ (calcd. 457.2015) 


\section{General Polymerization Procedure:}

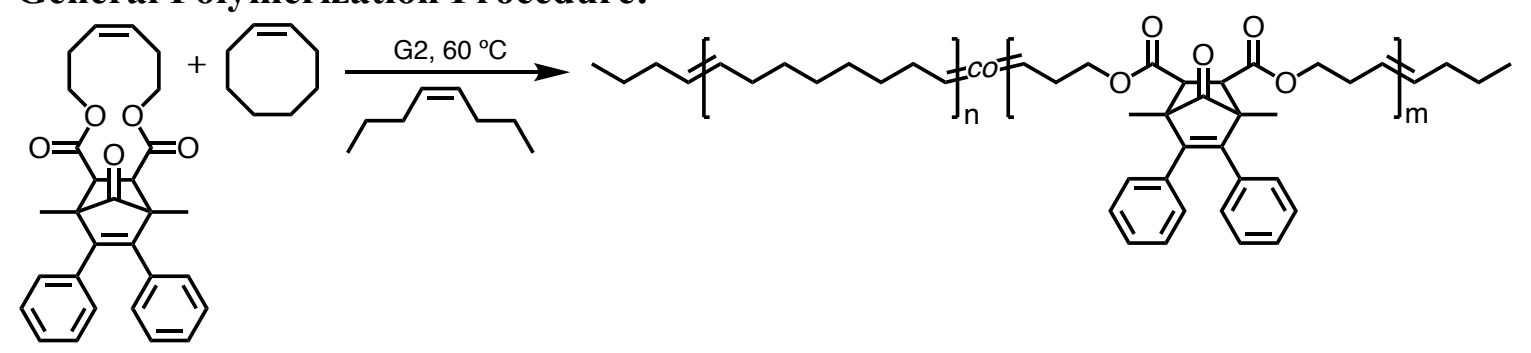

As an example, to a $2 \mathrm{~mL}$ oven dried vial equipped with a stir bar, $100 \mathrm{mg}(0.22 \mathrm{mmol})$ of $\mathbf{3}$ was added and purged with argon for 10 minutes. To the vial, $28.5 \mu \mathrm{L}(0.22 \mathrm{mmol})$ of cis-cyclooctene that was run through neutral alumina and was also injected. Stock solutions of G2 and the CTA agent were made as follows. To a $10 \mathrm{~mL}$ volumetric flask, $7.1 \mathrm{mg}$ of $\mathrm{G} 2$ was added and purged with argon for $10 \mathrm{~min}$ before diluting to the mark with $\mathrm{CHCl}_{3}$. To a separate $10 \mathrm{~mL}$ volumetric flask, $5.6 \mu \mathrm{L}$ of $\mathrm{cis}$-4-octene was added and diluted to the mark with $\mathrm{CHCl}_{3}$. To the $2 \mathrm{~mL}$ vial, $131.9 \mu \mathrm{L}$ of both the CTA and $\mathrm{G} 2$ solutions were added and quickly allowed to stir at rt until $\mathbf{3}$ was fully solubilized. At this time, the vial was heated to $60^{\circ} \mathrm{C}$ and allowed to stir overnight. At this time, $0.1 \mathrm{~mL}$ of ethyl vinyl ether and $1 \mathrm{~mL}$ of DCM were added and allowed to stir at $\mathrm{rt}$ for $30 \mathrm{~min}$ before precipitating into $20 \mathrm{~mL}$ of $\mathrm{MeOH}$ to give a white solid.

\section{General Sonication Procedure:}

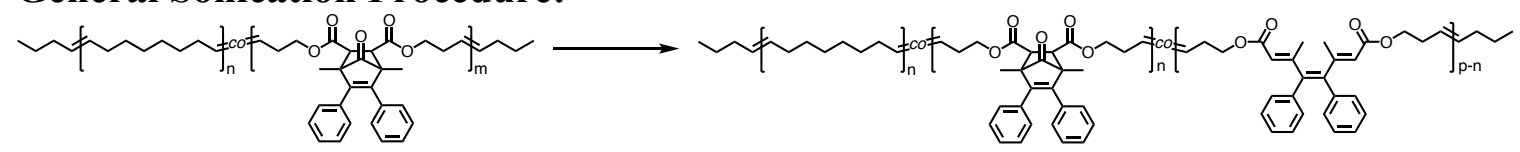

To an oven-dried Suslick cell, ${ }^{12} 12 \mathrm{~mL}$ of a $1 \mathrm{mg} \cdot \mathrm{mL}^{-1}$ solution of P2 in THF was filtered through a cotton plug and added. The solution was sparged for $10 \mathrm{~min}$ with argon before being placed in a cooling bath at $-10^{\circ} \mathrm{C}$. At this time, sonication was initiated with a constant flow of argon, and $1 \mathrm{~mL}$ aliquots were taken at predetermined times. Aliquots were concentrated a dried before SEC and ${ }^{1} \mathrm{H}-\mathrm{NMR}$ analysis. 


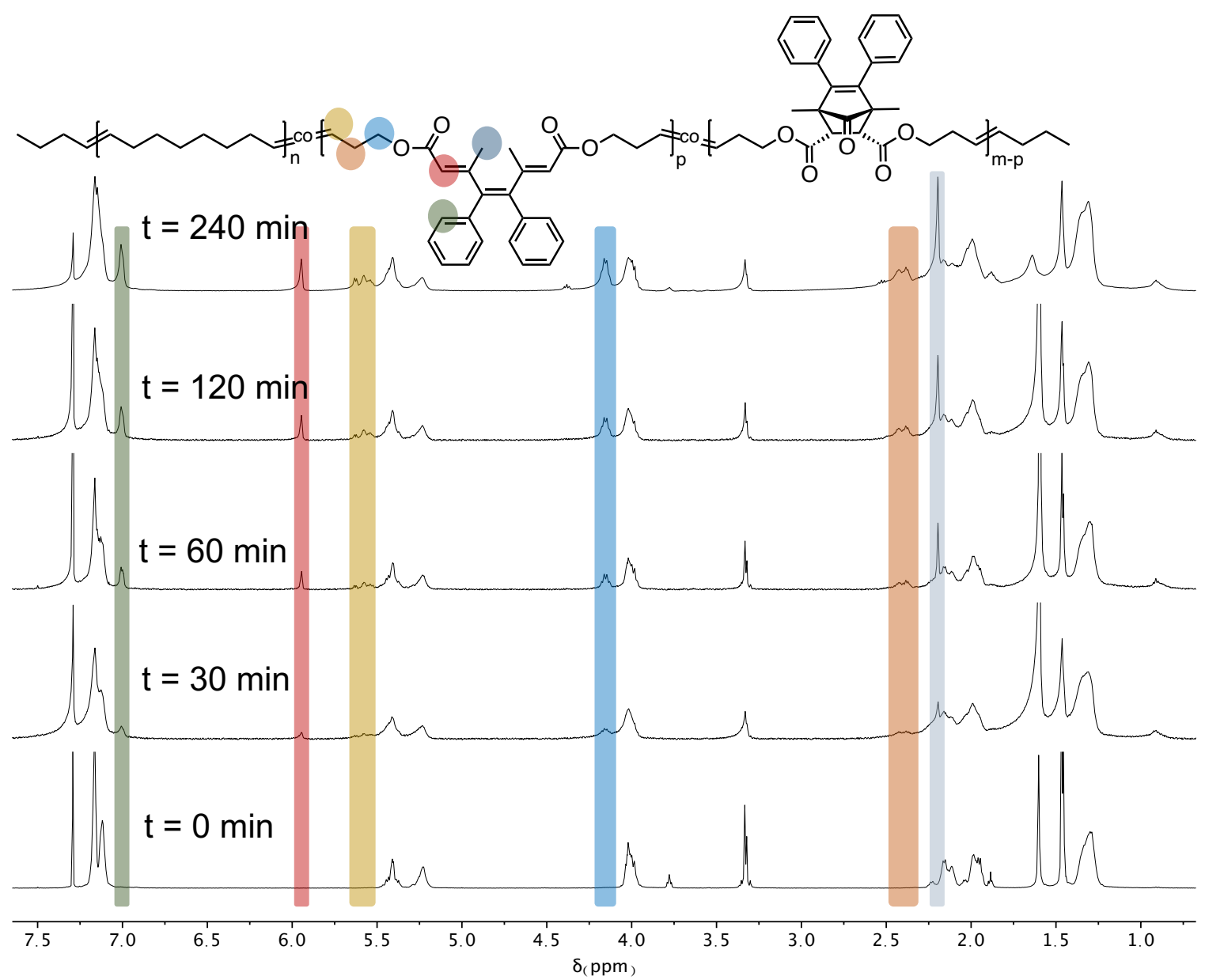

Figure S1. Representative ${ }^{1} \mathrm{H}$ NMR of $\mathbf{P 2}$ upon sonication (500 MHz, $\mathrm{CDCl}_{3}$ ). Growth of new peaks from activated cis-NEO were color-coded. 


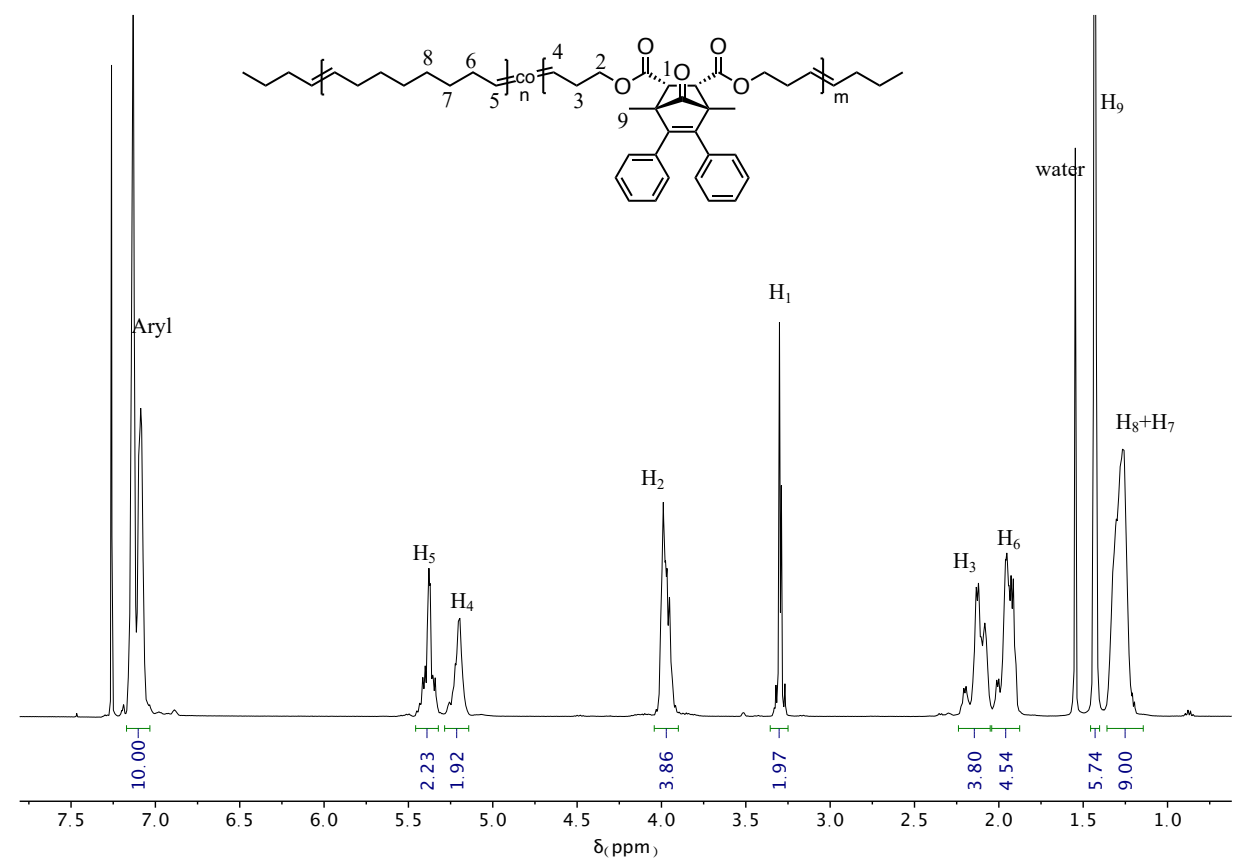

Figure S2. Representative ${ }^{1} \mathrm{H}$ NMR of $\mathbf{P 2}\left(500 \mathrm{MHz}, \mathrm{CDCl}_{3}\right)$. cis-NEO incorporation $\%$ was calculated from the integrated intensity ratio of the olefin resonances $\left(\mathrm{H}_{4}\right.$ and $\left.\mathrm{H}_{5}\right)$.

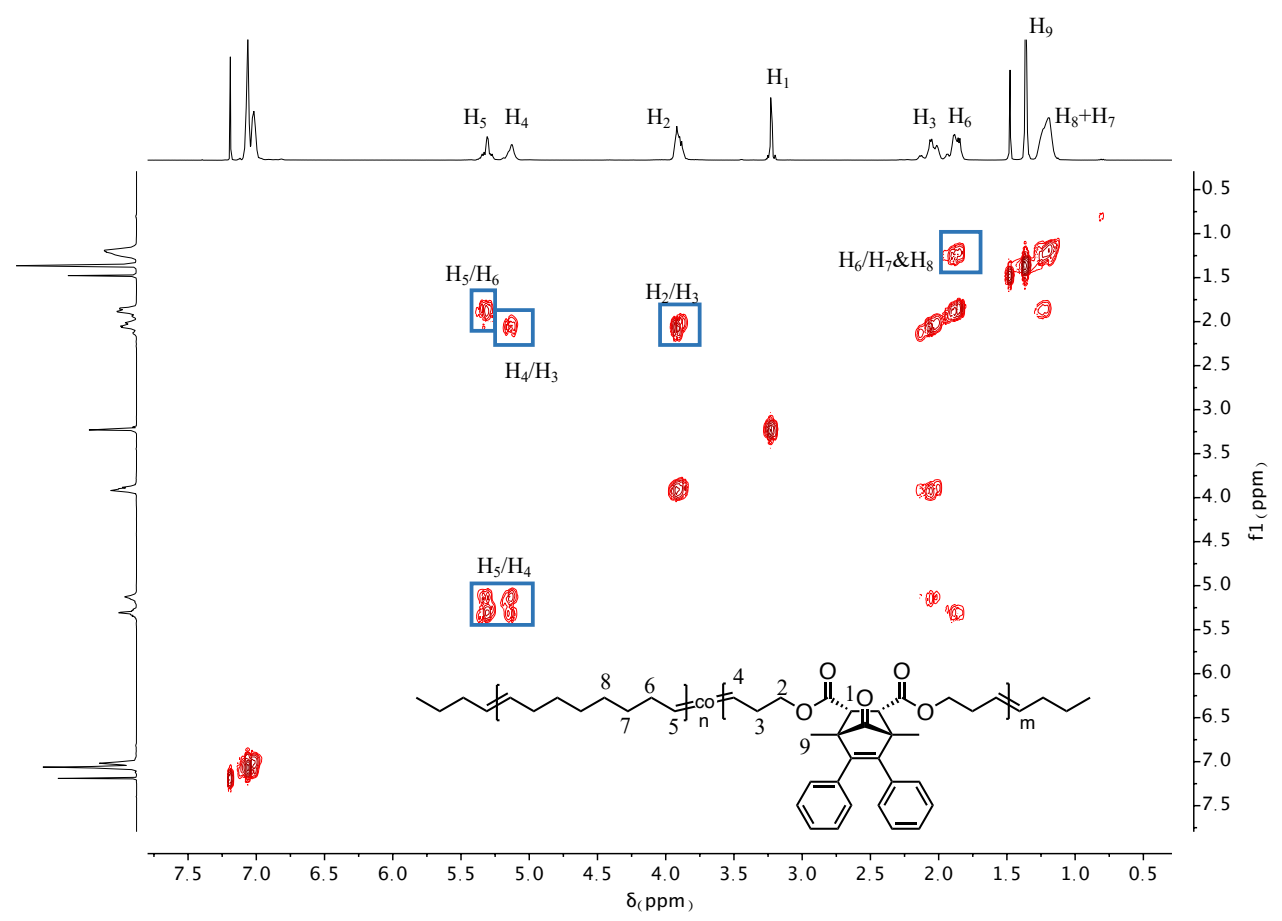

Figure S3. 2D ${ }^{1} \mathrm{H}-{ }^{1} \mathrm{H}$ COSY NMR of $\mathbf{P} 2\left(500 \mathrm{MHz}, \mathrm{CDCl}_{3}\right)$. Correlations are highlighted. 


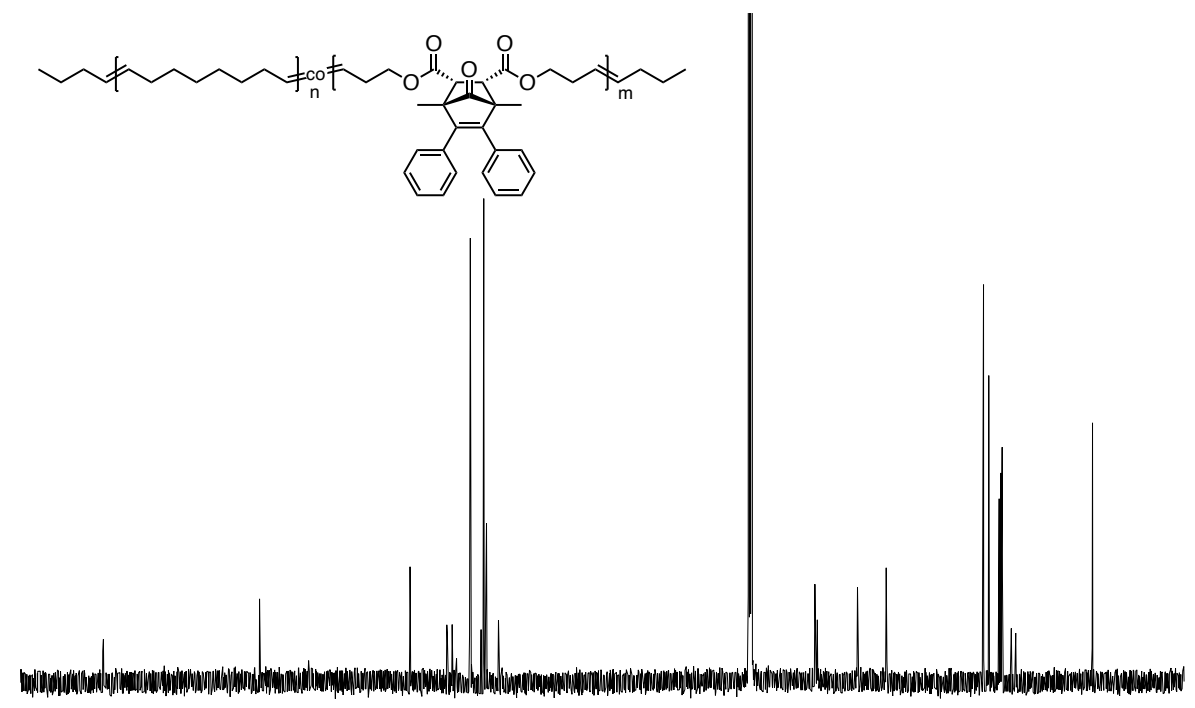

\begin{tabular}{lllllllllllllllllllllllll}
\hline 210 & 200 & 190 & 180 & 170 & 160 & 150 & 140 & 130 & 120 & $\begin{array}{c}110 \\
\delta_{(\mathrm{ppm})}\end{array}$ & 100 & 90 & 80 & 70 & 60 & 50 & 40 & 30 & 20 & 10 & 0
\end{tabular}

Figure S4. Representative ${ }^{13} \mathrm{C}$ NMR of $\mathbf{P 2}\left(500 \mathrm{MHz}, \mathrm{CDCl}_{3}\right)$.

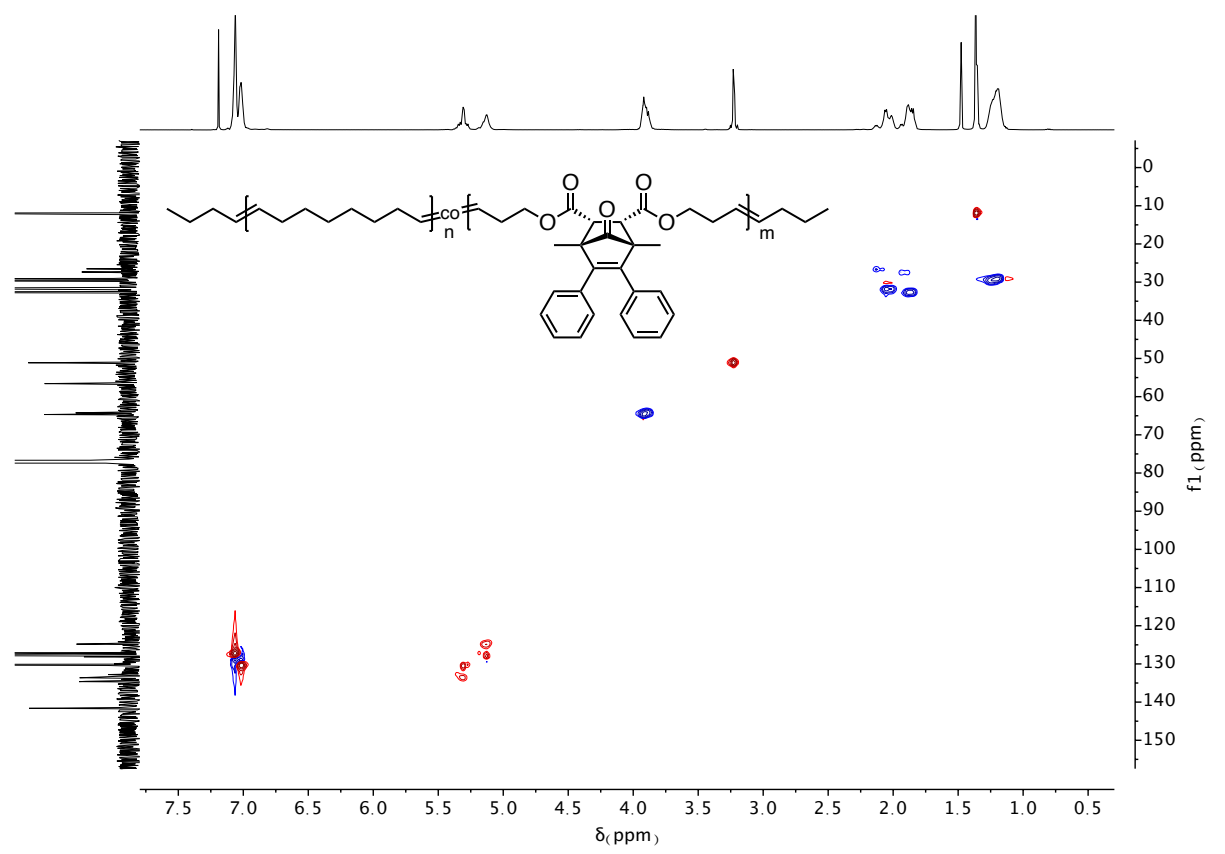

Figure S5. 2D ${ }^{1} \mathrm{H}-{ }^{13} \mathrm{C}$ HSQC NMR of $\mathbf{P 2}\left(500 \mathrm{MHz}, \mathrm{CDCl}_{3}\right)$. 


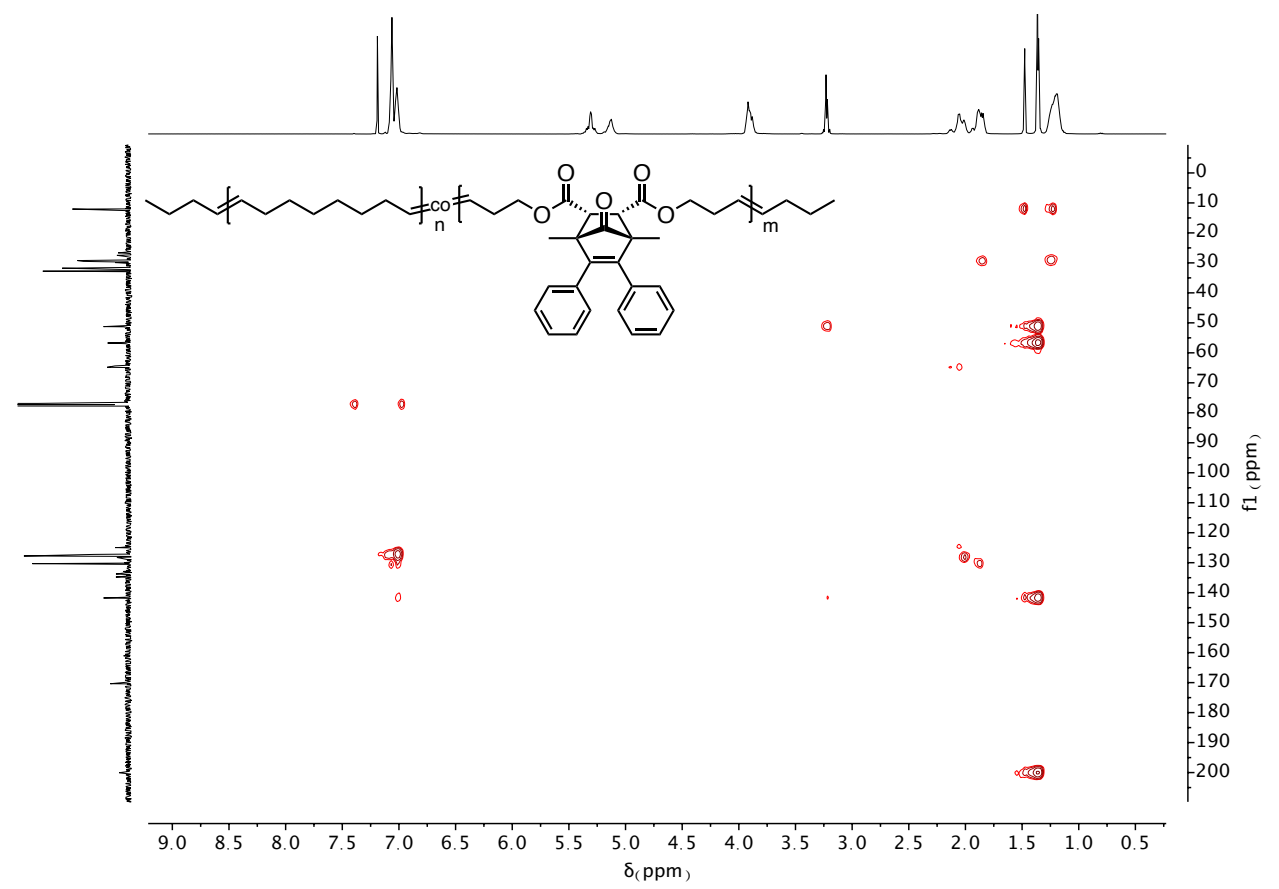

Figure S6. $\left.2 \mathrm{D}{ }^{1} \mathrm{H}-{ }^{13} \mathrm{C} \mathrm{HMBC} \mathrm{NMR} \mathrm{of} \mathrm{P2} \mathrm{(500} \mathrm{MHz,} \mathrm{CDCl}_{3}\right)$.

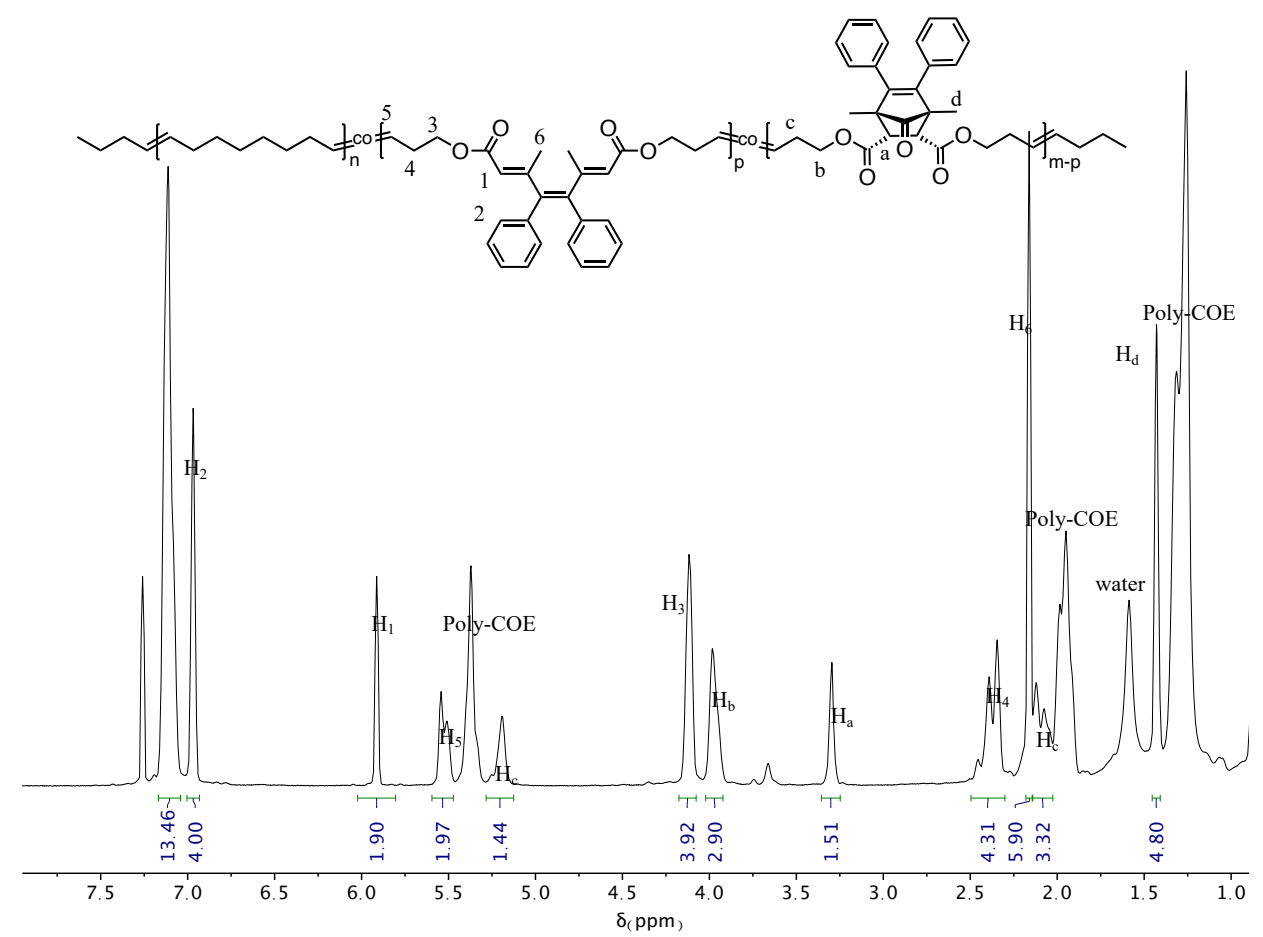

Figure S7. Representative ${ }^{1} \mathrm{H}$ NMR of SP2 $\left(500 \mathrm{MHz}, \mathrm{CDCl}_{3}\right)$, Activation\% $(\Phi)$ was calculated from the integrated intensity ratio of $\mathrm{H}_{1}$ to $\mathrm{H}_{\mathrm{a}}$. 

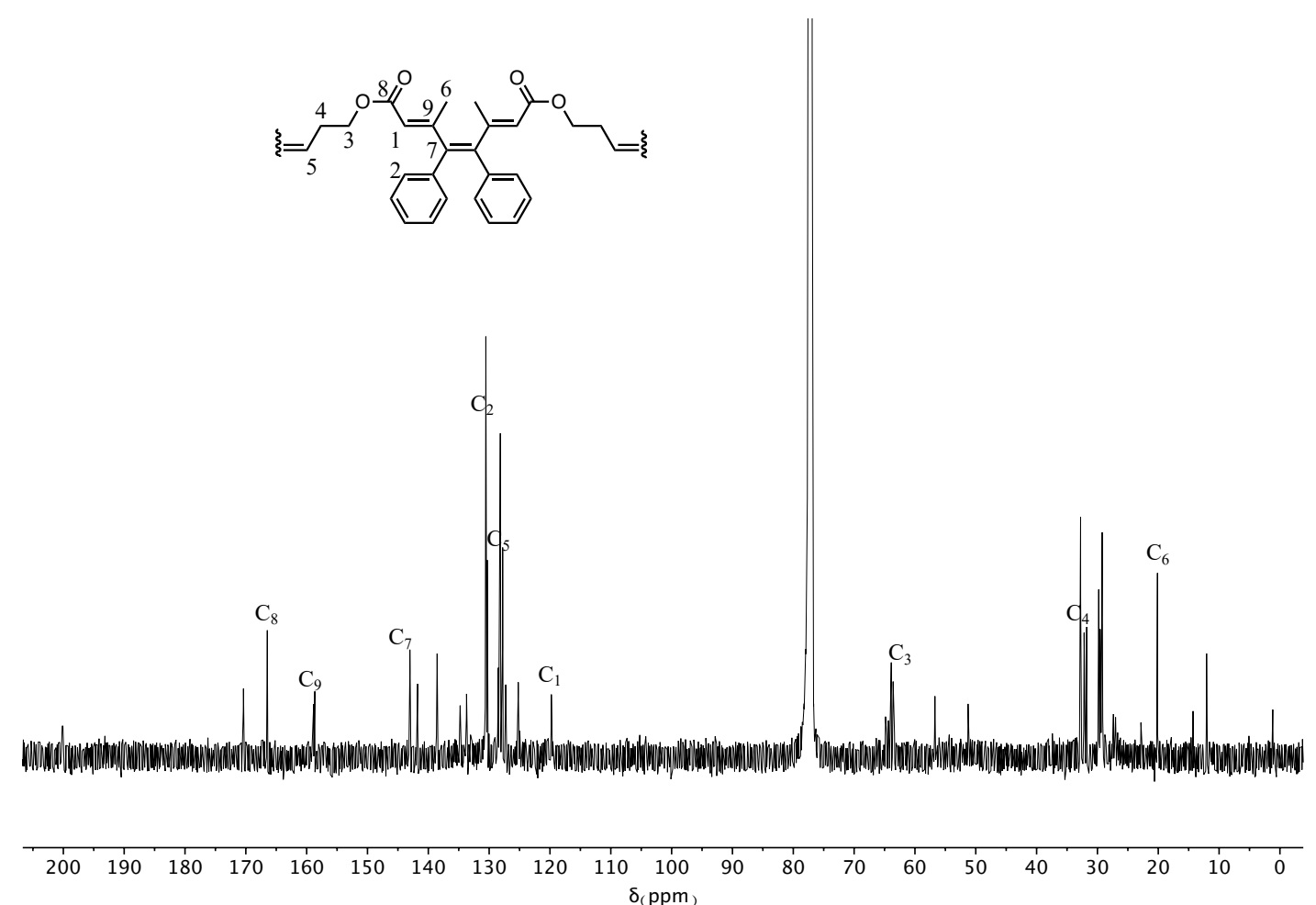

Figure S8. Representative ${ }^{13} \mathrm{C}$ NMR of SP2 $\left(500 \mathrm{MHz}, \mathrm{CDCl}_{3}\right)$. Carbons in the activated motif were assigned.
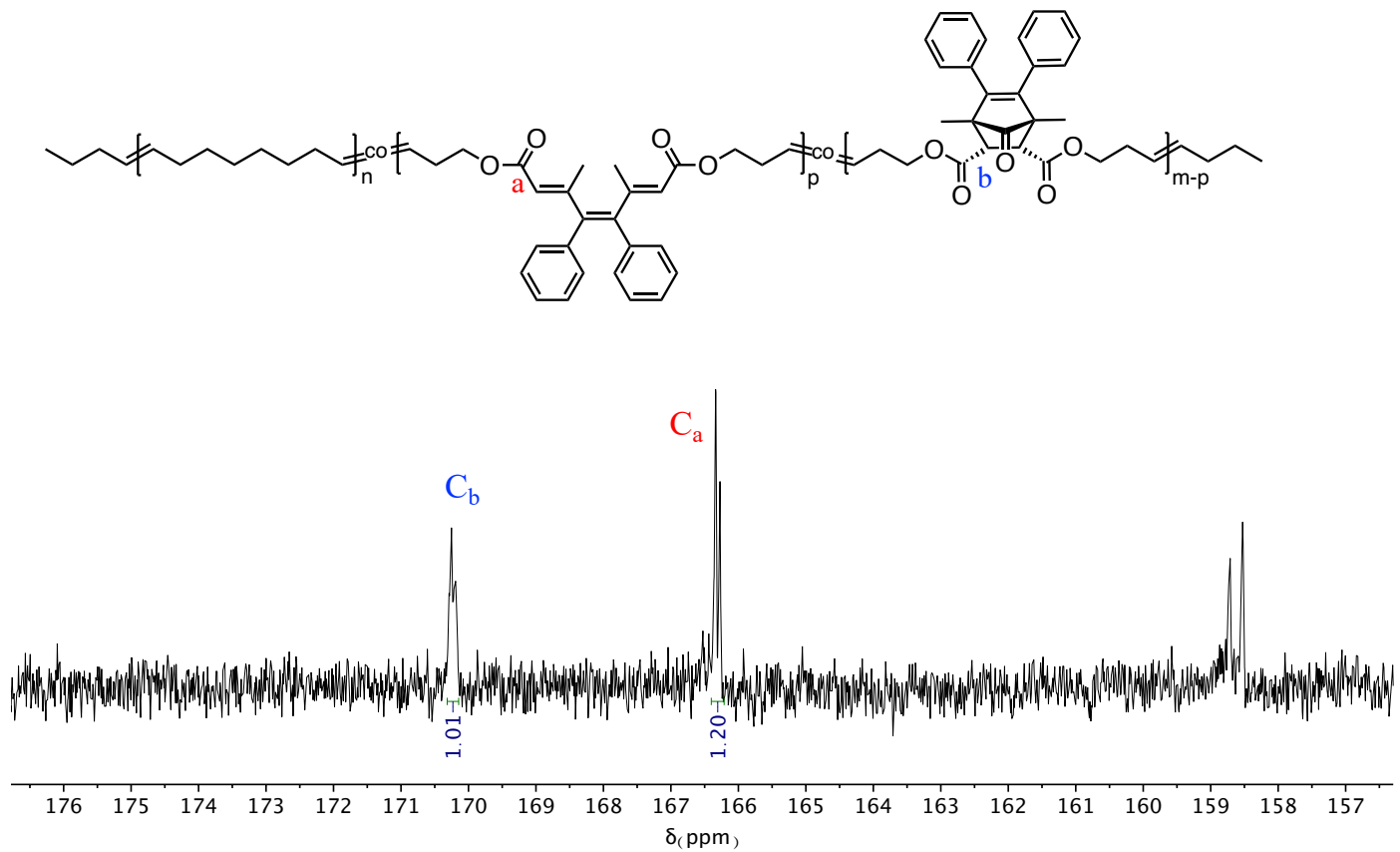

Figure S9. Partial quantitative ${ }^{13} \mathrm{C}$ NMR of SP2 (500 MHz, $\left.\mathrm{CDCl}_{3}\right)$. Activation\% (Ф) was calculated from the integrated intensity ratio between carbonyl $\mathrm{C}_{\mathrm{a}}$ and $\mathrm{C}_{\mathrm{b}}$. 


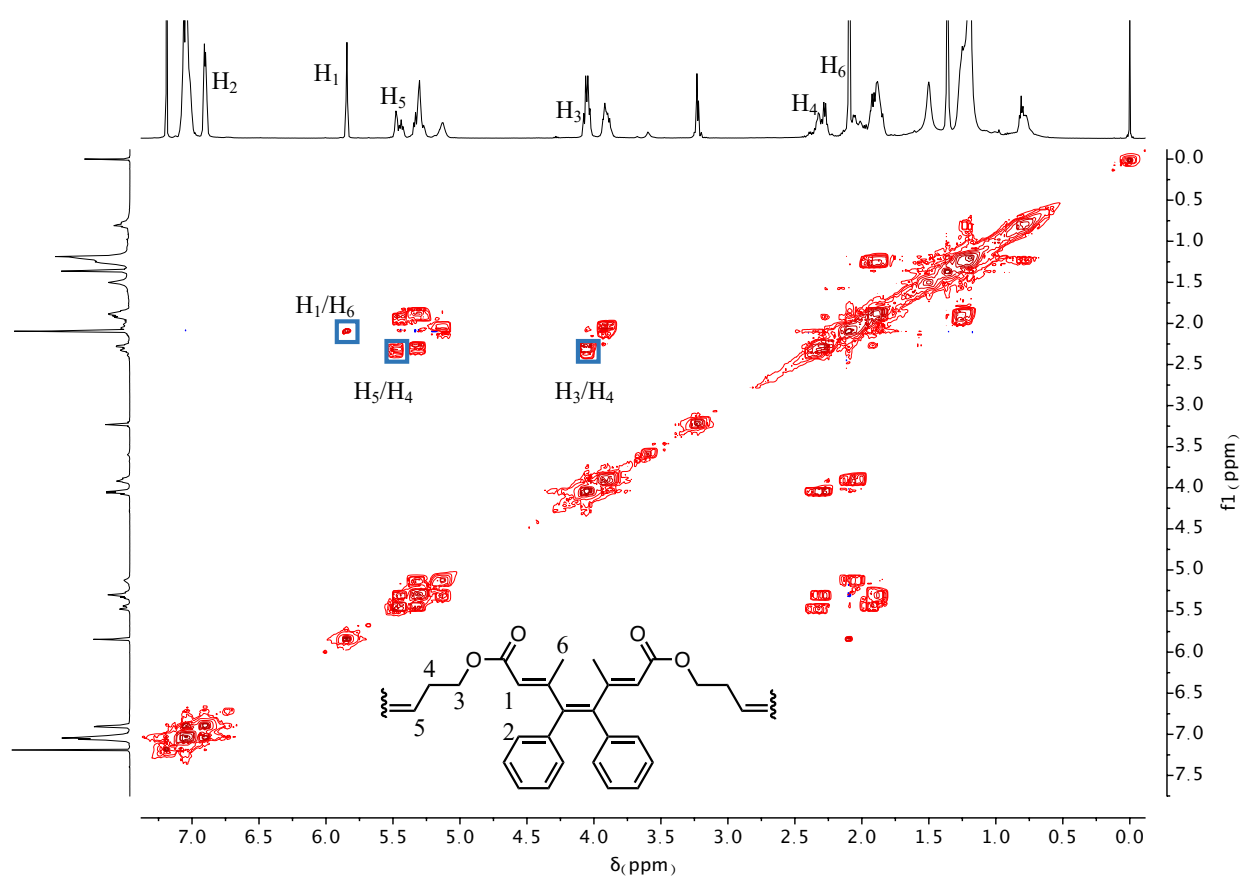

Figure S10. 2D ${ }^{1} \mathrm{H}-{ }^{1} \mathrm{H}$ COSY NMR of SP2 (500 MHz, $\left.\mathrm{CDCl}_{3}\right)$. Protons in activated cisNEO structure were highlighted.

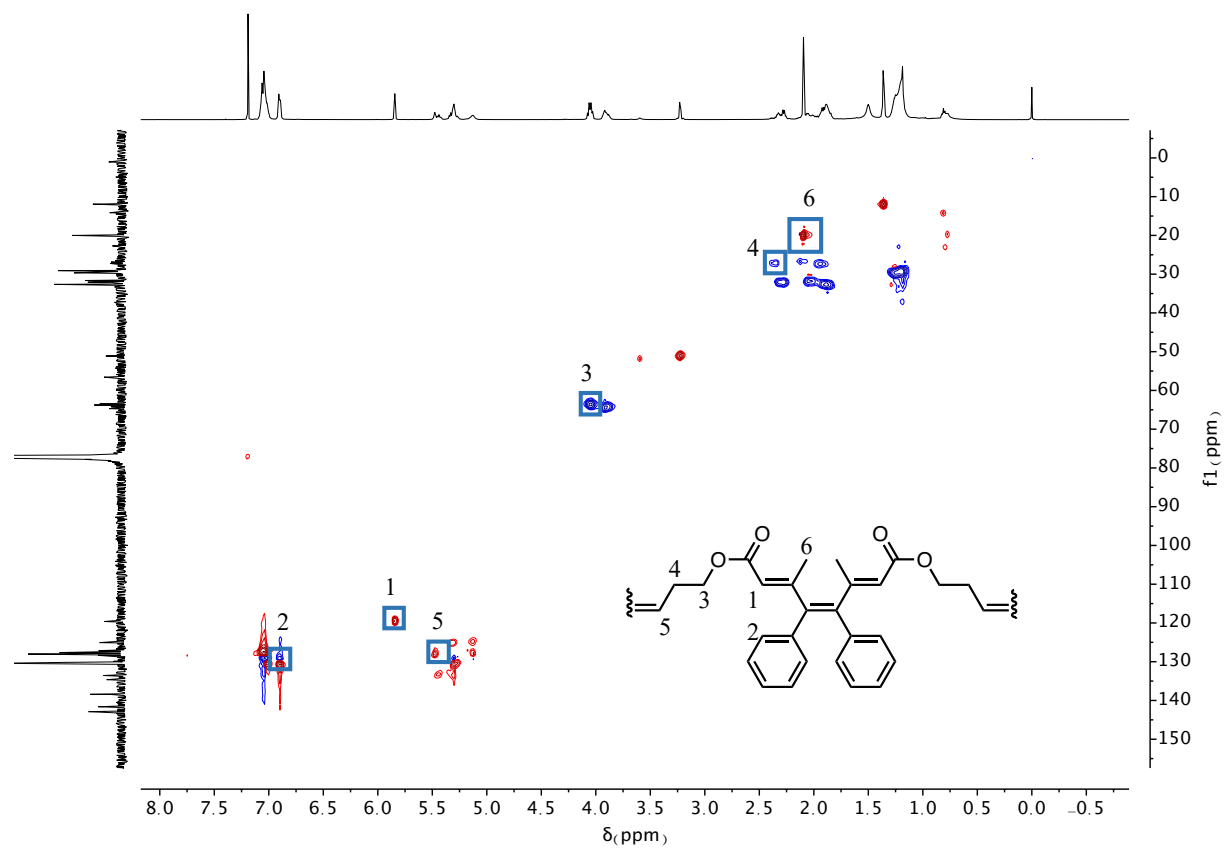

Figure S11. 2D ${ }^{1} \mathrm{H}_{-}{ }^{13} \mathrm{C}$ HSQC NMR of SP2 (500 MHz, $\left.\mathrm{CDCl}_{3}\right)$. Correlations in activated cis-NEO structure were highlighted. 


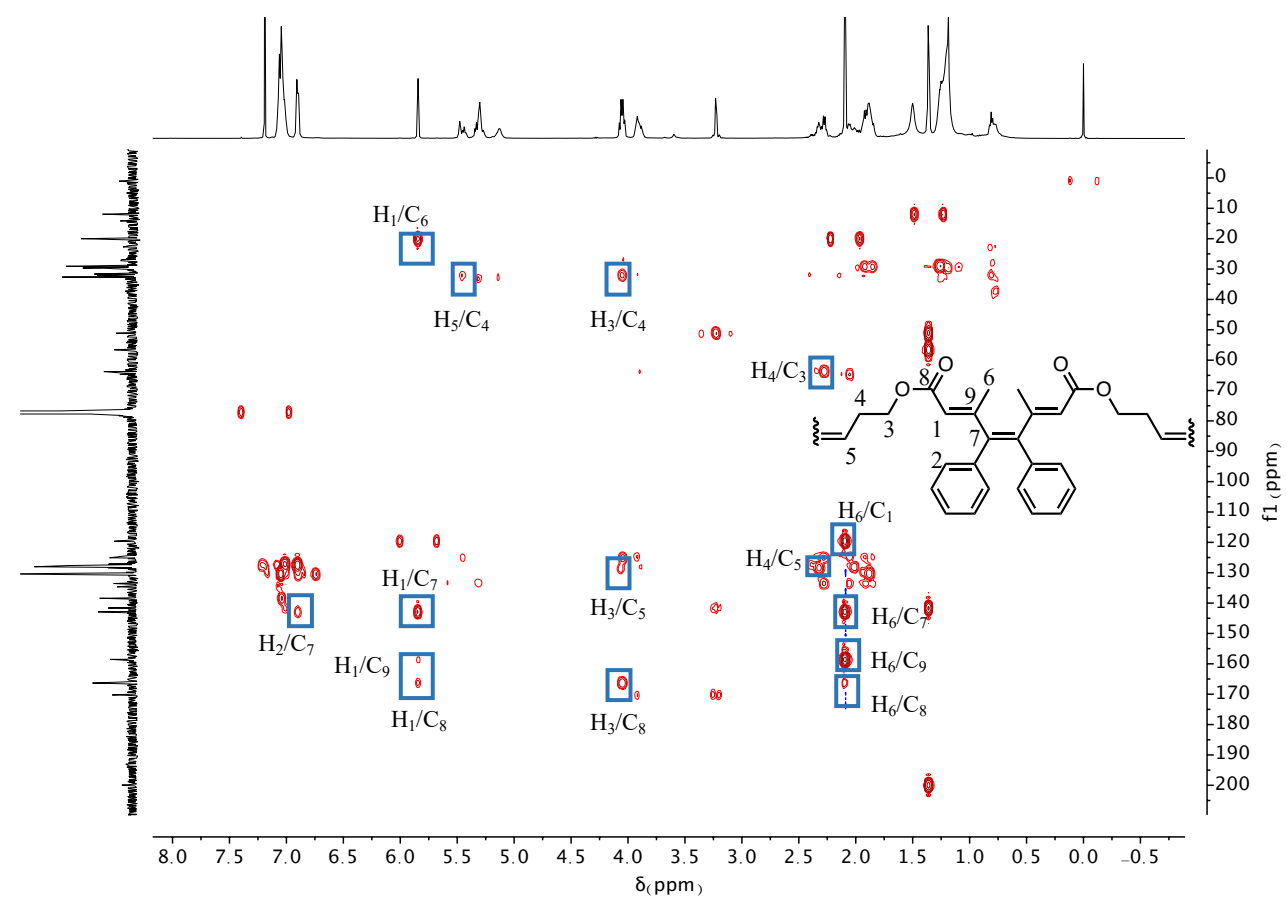

Figure S12. 2D ${ }^{1} \mathrm{H}_{-}{ }^{13} \mathrm{C}$ HMBC NMR of SP2 (500 MHz, $\left.\mathrm{CDCl}_{3}\right)$. Correlations in activated cis-NEO structure was highlighted.
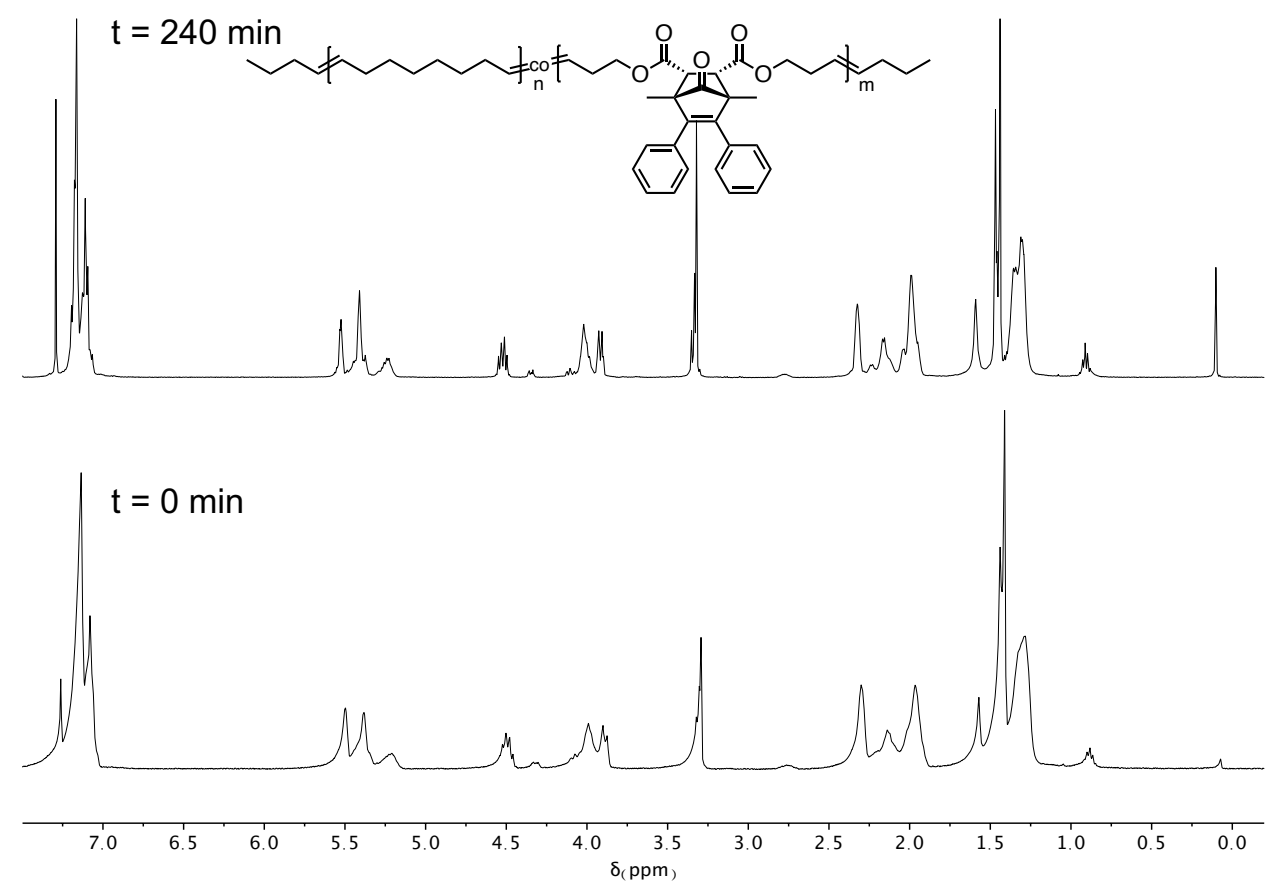

Figure S13. ${ }^{1} \mathrm{H}-\mathrm{NMR}$ of control P2 $\left(M_{\mathrm{n}}=6.2 \mathrm{kDa}\right)$ upon sonication $\left(500 \mathrm{MHz}, \mathrm{CDCl}_{3}\right)$. No new peaks were observed upon 240 min of sonication. 


\section{Stereochemistry Determination after Activation}

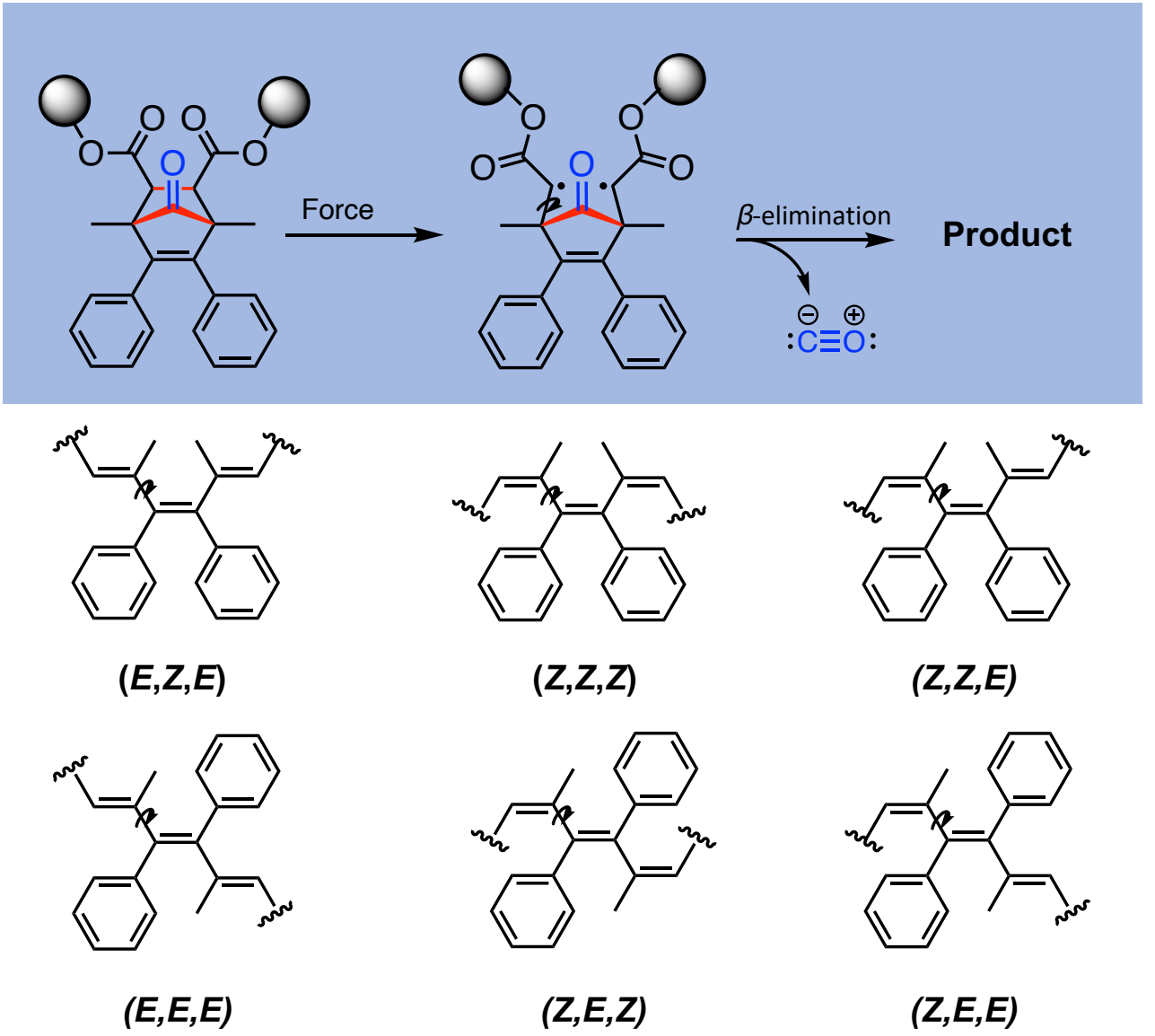

Figure S14. Potential stereoisomers of NEO mechanophore after activation. Only most extended conformation was drawn for each isomer. Black curved arrows indicate potentially rotatable bonds. 


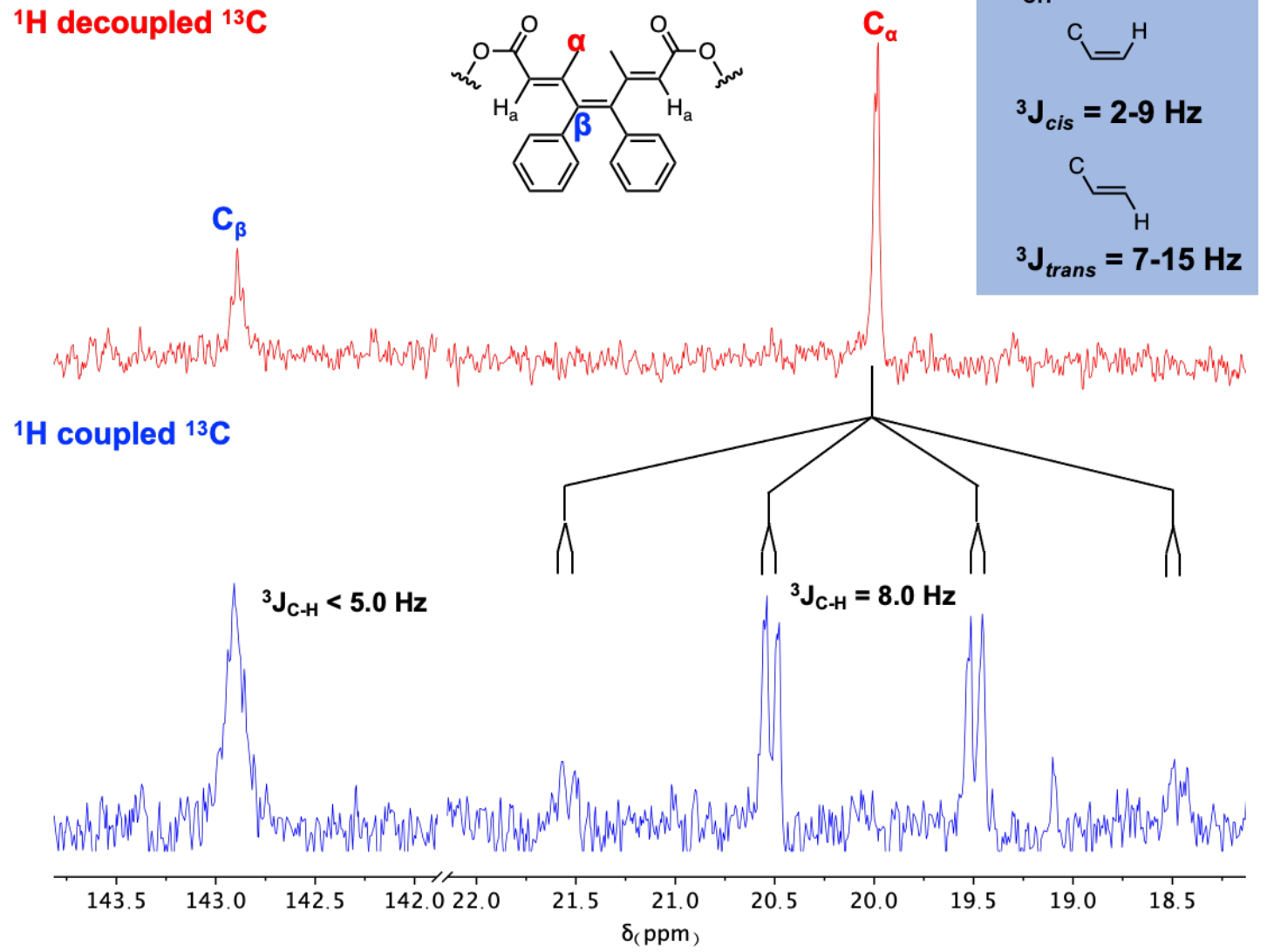

Figure S15. Stacked ${ }^{13} \mathrm{C}$ NMR of selected peaks of $\mathbf{S P 2}\left(500 \mathrm{MHz}, \mathrm{CDCl}_{3}\right)$

The sharp singlet peaks around $5.9 \mathrm{ppm}$ and $2.2 \mathrm{ppm}$ in ${ }^{1} \mathrm{H}$-NMR strongly indicated a single symmetrical product, excluding the $(Z, Z, E)$ and $(Z, E, E)$ isomers. While a doublet of quartets (coupling from $\mathrm{H}_{\mathrm{a}}$ as well as the 3 methyl protons) was observed for $\mathrm{C}_{\alpha}$ in protoncoupled ${ }^{13} \mathrm{C}$ NMR, only broadening of peaks was seen for $\mathrm{C}_{\beta}$ (both ${ }^{3} J_{\mathrm{C}-\mathrm{H}}$ coupling between $\mathrm{H}_{a} / \mathrm{C}_{\beta}$ and methyl proton/ $\mathrm{C}_{\beta}$ are expected), indication relatively small coupling constant. Although the ${ }^{3} J_{\mathrm{C}-\mathrm{H}}(8.0 \mathrm{~Hz})$ between $\mathrm{H}_{\mathrm{a}}$ and $\mathrm{C}_{\alpha}$ was at the borderline between cis and trans, ${ }^{4}$ the significantly lower ${ }^{3} J_{\mathrm{C}-\mathrm{H}}$ between $\mathrm{H}_{\mathrm{a}}$ and $\mathrm{C}_{\beta}$ was strongly indicative of the cis configuration between $\mathrm{H}_{\mathrm{a}}$ and $\mathrm{C}_{\beta}$, further excluding $(Z, Z, Z)$ and $(Z, E, Z)$ isomers. $(E, Z, E)$ and $(E, E, E)$ isomers were differentiated from detailed NOE analysis. 


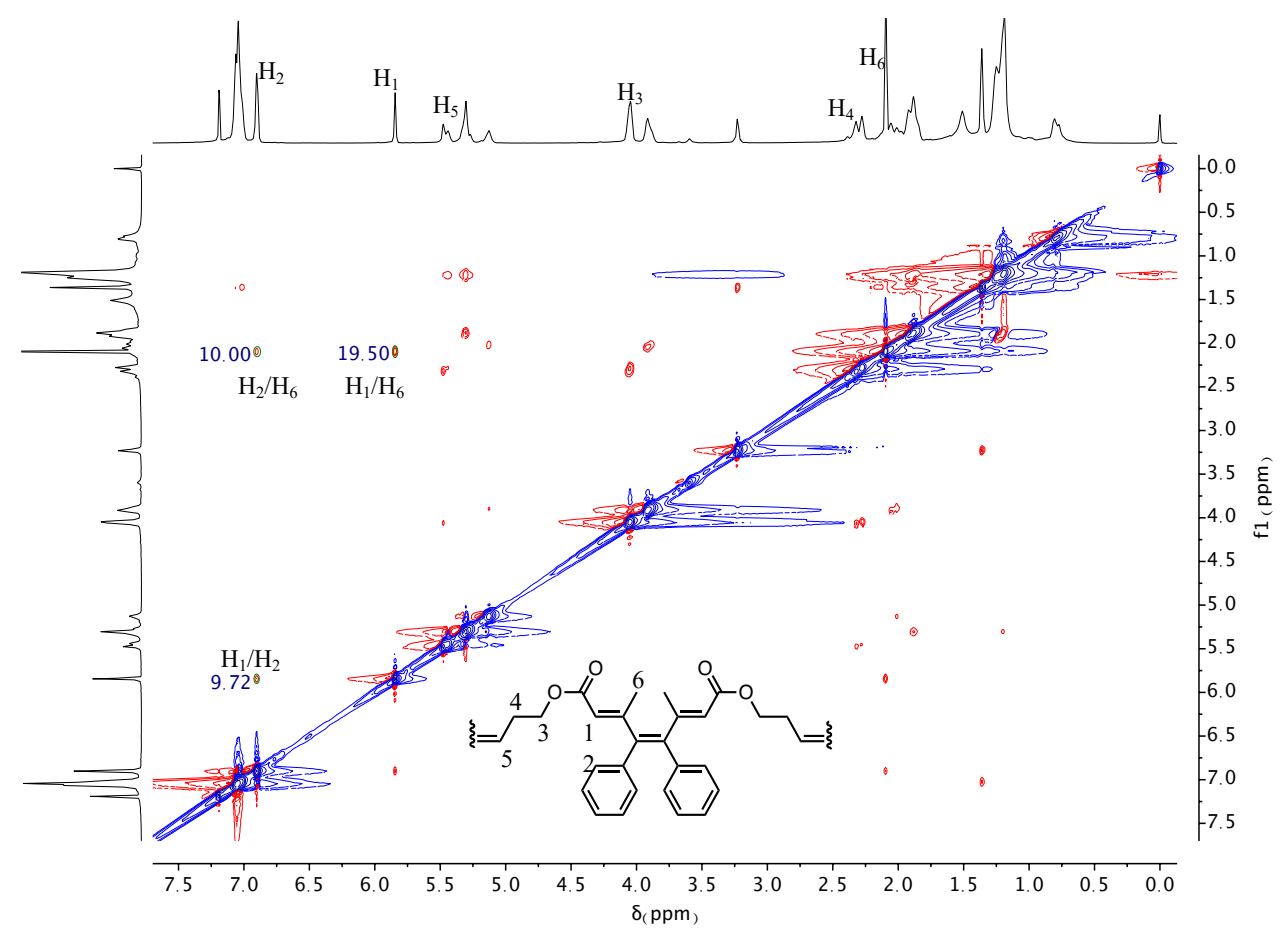

Figure S16. 2D ${ }^{1} \mathrm{H}-{ }^{1} \mathrm{H}$ ROESY NMR of $\mathbf{S P 2}\left(500 \mathrm{MHz}, \mathrm{CDCl}_{3}\right)$. Relative NOE intensity was determined by integration between $\mathrm{H}_{1}, \mathrm{H}_{2}$, and $\mathrm{H}_{6}$.

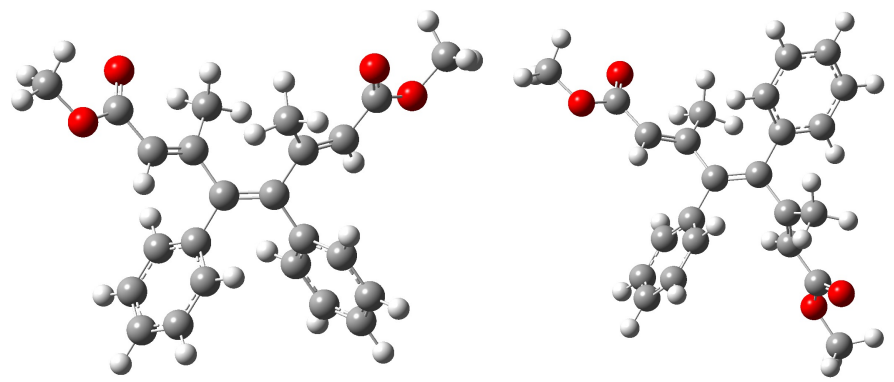

$(E, Z, E)$

$(E, E, E)$

Figure S17. Optimized structures of $(E, Z, E)$ and $(E, E, E)$ isomers at the B3LYP/6-31G* level of theory.

The relative NOE intensity from 2D-ROESY NMR was 9.72/2: 10.00/6 :19.50/3 = 4.86: 1.67: 6.50 between $\mathrm{H}_{1} / \mathrm{H}_{2}, \mathrm{H}_{2} / \mathrm{H}_{6}$, and $\mathrm{H}_{1} / \mathrm{H}_{6}$ after normalization, suggesting the interproton distance on average to be $d_{26}>d_{12}>d_{16}$. In the optimized structure, the close proximity between $\mathrm{H}_{2}$ and $\mathrm{H}_{6}$ in the $(E, E, E)$ isomer is inconsistent with the observed NOE signal, while the $\mathrm{H}_{2}$ and $\mathrm{H}_{6}$ are relatively far away from each other in the $(E, Z, E)$ optimized structure, consistent with NOE observations. Since the smallest NOE value was observed between $\mathrm{H}_{2}$ and $\mathrm{H}_{6}$ experimentally, the $(E, Z, E)$ configuration is more consistent with the ROESY data. 


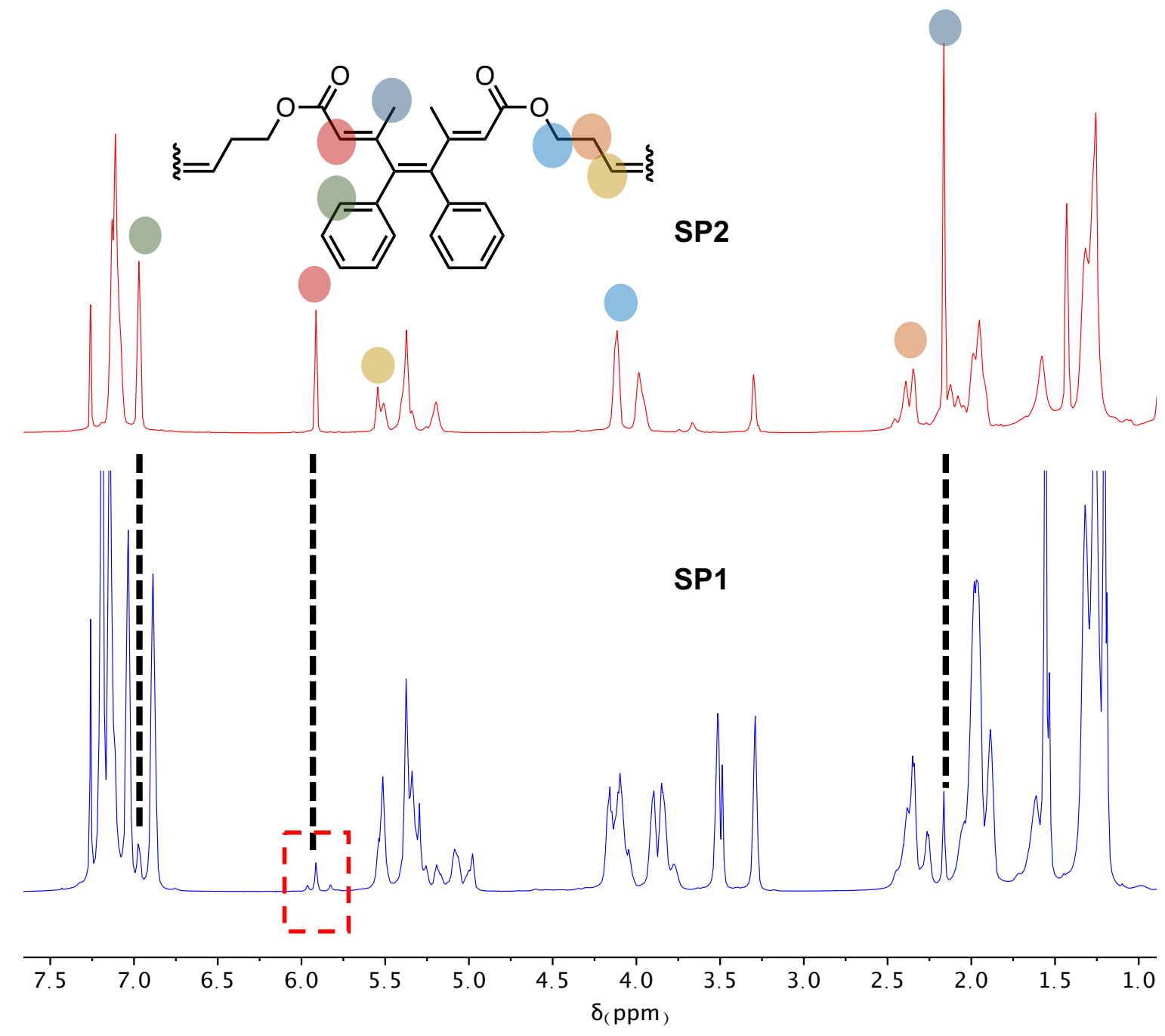

Figure S18. Stacked ${ }^{1} \mathrm{H}$ NMR P2 $\left(M_{\mathrm{n}}=158.8 \mathrm{kDa}, 47.1 \%\right.$ incorporation, $\left.\Phi=58.8 \%\right)$ and P1 $\left(M_{\mathrm{n}}=143.7 \mathrm{kDa}, 46.8 \%\right.$ incorporation, $\left.\Phi=12.0 \%\right)$ upon 240 min sonication $(500 \mathrm{MHz}$, $\mathrm{CDCl}_{3}$ ). Two small resonances at $\delta \sim 5.9 \mathrm{ppm}$ indicated the generation of other isomers in SP1. 

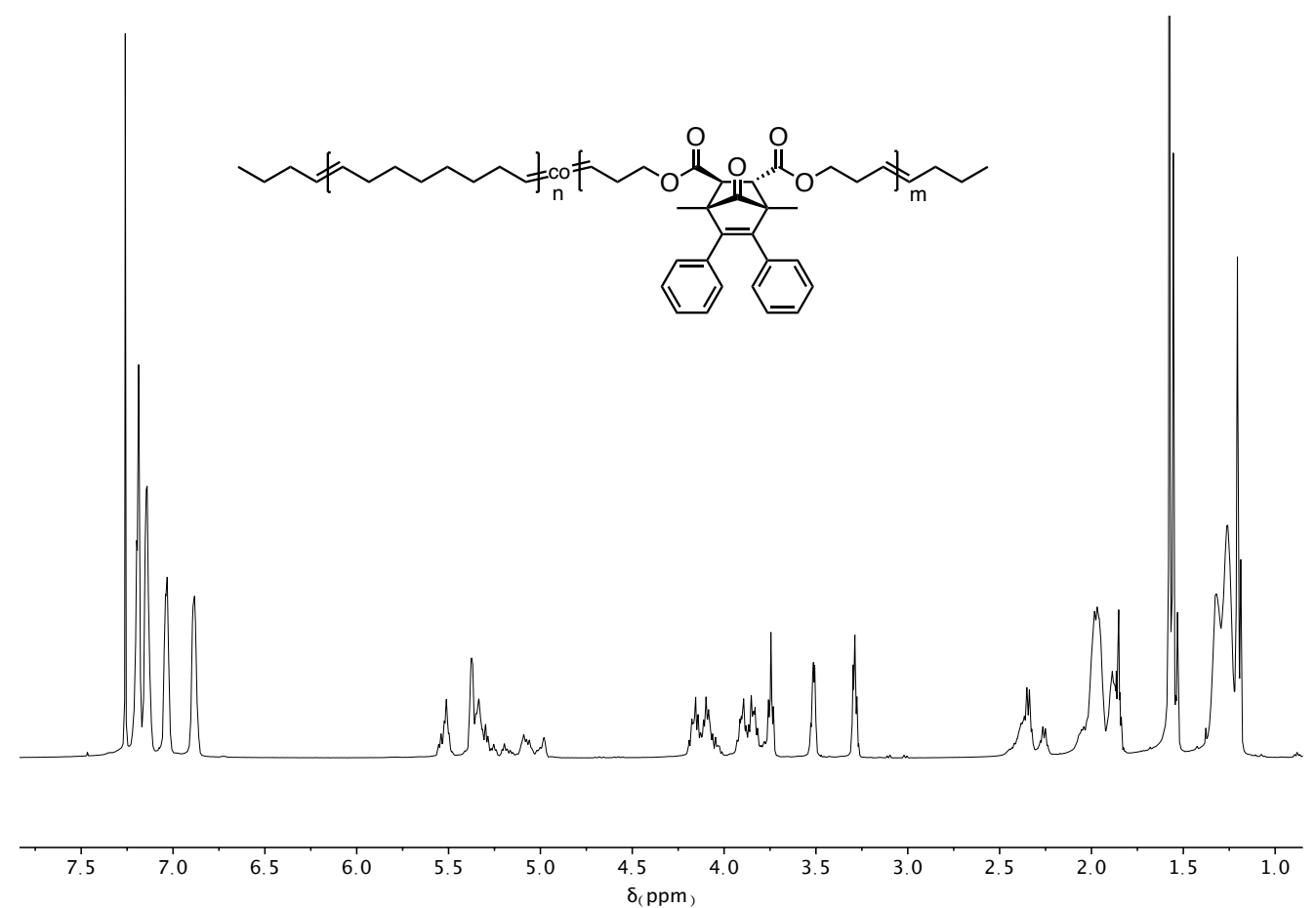

Figure S19. ${ }^{1} \mathrm{H}$ NMR $\left(500 \mathrm{MHz}, \mathrm{CDCl}_{3}\right)$ of $\mathbf{P 1}\left(M_{n}=143.7 \mathrm{kDa}, 46.8 \%\right.$ incorporation $)$ $\left(500 \mathrm{MHz}, \mathrm{CDCl}_{3}\right)$.

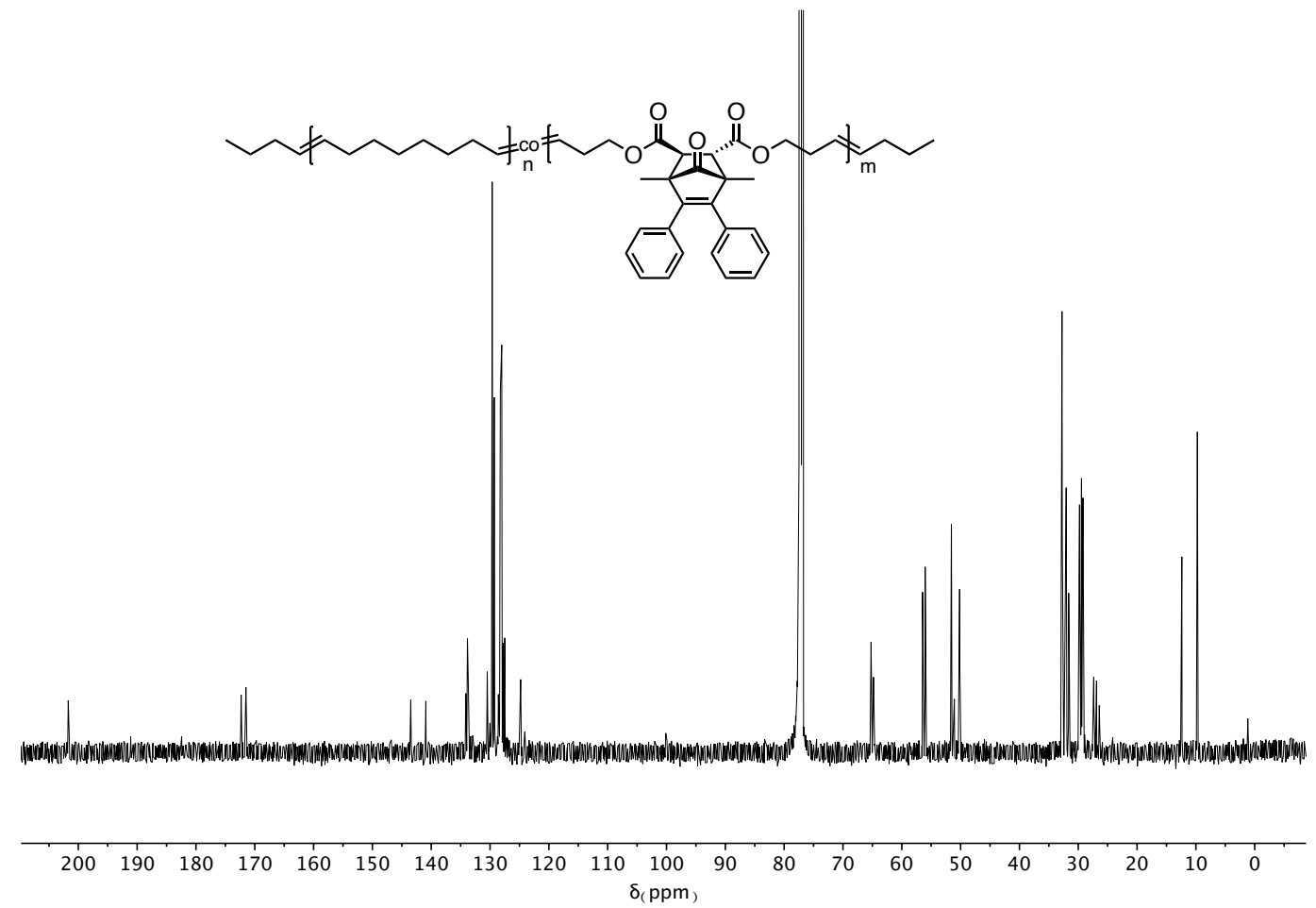

Figure S20. ${ }^{13} \mathrm{C}$ NMR $\left(126 \mathrm{MHz}, \mathrm{CDCl}_{3}\right)$ of $\mathbf{P 1}\left(M_{n}=143.7 \mathrm{kDa}, 46.8 \%\right.$ incorporation $)$. 


\section{X-Ray Single Crystal Structures}

\section{Crystal Structure of 3 and 6 ( $E$-isomer)}

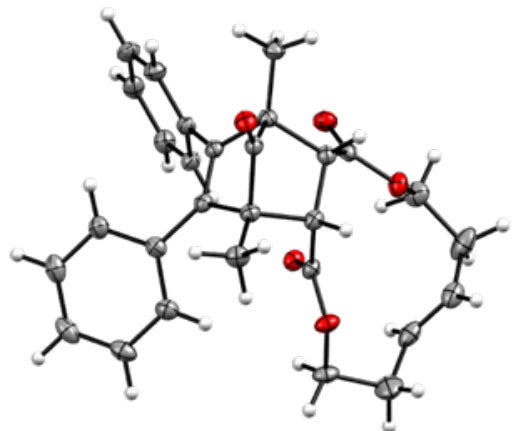

3

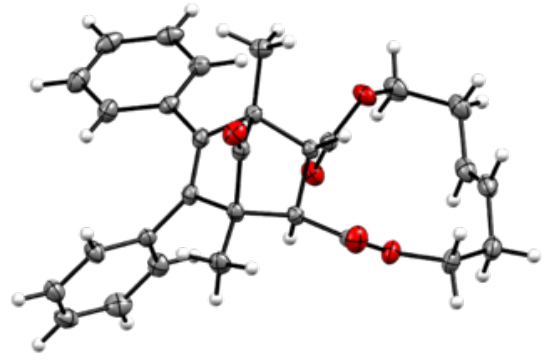

$6(E$ isomer $)$

Figure S21. Crystal structure of $\mathbf{3}$ and $\mathbf{6}$ ( $E$ isomer).

Single crystals suitable for X-ray diffraction analysis for both $\mathbf{3}$ and $\mathbf{6}$ (E isomer) were obtained by slow diffusion of hexanes into $\mathrm{CHCl}_{3}$ solution.

Intensity data were collected on a Bruker D8 Venture kappa diffractometer equipped with a Photon II CPAD detector. An I $\mu$ s microfocus Mo source $(\lambda=0.71073 \AA$ ) (ed83k) or $\mathrm{Cu}$ source $(\lambda=1.54178 \AA$ ) (ed63L) coupled with a multi-layer mirror monochromator provided the incident beam. The sample was mounted on a $0.3 \mathrm{~mm}$ nylon loop with the minimal amount of Paratone-N oil. Data was collected as a series of $\varphi$ and/or $\omega$ scans. Data was collected at $100 \mathrm{~K}$ (ed83k) or $120 \mathrm{~K}$ (ed63L) using a cold stream of $\mathrm{N}_{2}(\mathrm{~g})$. The collection, cell refinement, and integration of intensity data was carried out with the APEX3 software. ${ }^{8}$ A multi-scan absorption corrections was performed with SADABS. ${ }^{9}$ The structures were phased with intrinsic methods using SHELXT ${ }^{10}$ and refined with the full-matrix least-squares program SHELXL. ${ }^{11}$ 
Table S1. Crystal data and structure refinement for 3

\begin{tabular}{|c|c|c|}
\hline Empirical formula & \multicolumn{2}{|l|}{$\mathrm{C}_{29} \mathrm{H}_{28} \mathrm{O}_{5}$} \\
\hline Formula weight & \multicolumn{2}{|l|}{456.51} \\
\hline Temperature & \multicolumn{2}{|l|}{$100(2) \mathrm{K}$} \\
\hline Wavelength & \multicolumn{2}{|l|}{$0.71073 \AA$} \\
\hline Crystal system & \multicolumn{2}{|l|}{ Tetragonal } \\
\hline Space group & \multicolumn{2}{|l|}{$\mathrm{P} 42 / \mathrm{n}$} \\
\hline Unit cell dimensions & $\begin{array}{l}\mathrm{a}=17.1769(3) \AA \\
\mathrm{b}=17.1769(3) \AA \\
\mathrm{c}=15.6999(3) \AA\end{array}$ & $\begin{array}{l}\mathrm{a}=90^{\circ} \\
\mathrm{b}=90^{\circ} \\
\mathrm{g}=90^{\circ}\end{array}$ \\
\hline Volume & \multicolumn{2}{|l|}{$4632.19(18) \AA^{3}$} \\
\hline Z & \multicolumn{2}{|l|}{8} \\
\hline Density (calculated) & \multicolumn{2}{|l|}{$1.309 \mathrm{Mg} / \mathrm{m}^{3}$} \\
\hline Absorption coefficient & \multicolumn{2}{|l|}{$0.089 \mathrm{~mm}^{-1}$} \\
\hline$F(000)$ & \multicolumn{2}{|l|}{1936} \\
\hline Crystal size & \multicolumn{2}{|c|}{$0.248 \times 0.236 \times 0.230 \mathrm{~mm}^{3}$} \\
\hline Theta range for data collection & \multicolumn{2}{|l|}{2.371 to $27.109^{\circ}$. } \\
\hline Index ranges & \multicolumn{2}{|c|}{$-22<=\mathrm{h}<=22,-22<=\mathrm{k}<=22,-20<=1<=20$} \\
\hline Reflections collected & \multicolumn{2}{|l|}{124615} \\
\hline Independent reflections & \multicolumn{2}{|c|}{$5109[\mathrm{R}(\mathrm{int})=0.0548]$} \\
\hline Completeness to theta $=25.242^{\circ}$ & \multicolumn{2}{|c|}{$99.9 \%$} \\
\hline Absorption correction & \multicolumn{2}{|c|}{ Semi-empirical from equivalents } \\
\hline Max. and min. transmission & \multicolumn{2}{|l|}{0.7455 and 0.7214} \\
\hline Refinement method & \multicolumn{2}{|c|}{ Full-matrix least-squares on $\mathrm{F}^{2}$} \\
\hline Data / restraints / parameters & \multicolumn{2}{|c|}{$5109 / 43 / 329$} \\
\hline Goodness-of-fit on $\mathrm{F}^{2}$ & \\
\hline Final $R$ indices $[I>2 \operatorname{sigma}(I)]$ & \multicolumn{2}{|c|}{$\mathrm{R} 1=0.0389, \mathrm{wR} 2=0.0934$} \\
\hline $\mathrm{R}$ indices (all data) & \multicolumn{2}{|c|}{$\mathrm{R} 1=0.0457, \mathrm{wR} 2=0.0991$} \\
\hline Extinction coefficient & \multicolumn{2}{|l|}{$0.0026(3)$} \\
\hline Largest diff. peak and hole & \multicolumn{2}{|c|}{0.396 and -0.219 e. $\AA^{-3}$} \\
\hline
\end{tabular}


Table S2. Crystal data and structure refinement for 6 ( $E$ isomer)

\begin{tabular}{|c|c|c|}
\hline Empirical formula & $\mathrm{C}_{29} \mathrm{H}_{28} \mathrm{O}_{5}$ & \\
\hline Formula weight & 456.51 & \\
\hline Temperature & $120(2) \mathrm{K}$ & \\
\hline Wavelength & $1.54178 \AA$ & \\
\hline Crystal system & Orthorhombic & \\
\hline Space group & Pna2 1 & \\
\hline Unit cell dimensions & $\mathrm{a}=14.2847(3) \AA$ & $\mathrm{a}=90^{\circ}$ \\
\hline & $\mathrm{b}=14.0329(3) \AA$ & $\mathrm{b}=90^{\circ}$ \\
\hline & $\mathrm{c}=11.6373(2) \AA$ & $\mathrm{g}=90^{\circ}$ \\
\hline Volume & $2332.76(8) \AA^{3}$ & \\
\hline Z & 4 & \\
\hline Density (calculated) & $1.300 \mathrm{Mg} / \mathrm{m}^{3}$ & \\
\hline Absorption coefficient & $0.711 \mathrm{~mm}^{-1}$ & \\
\hline $\mathrm{F}(000)$ & 968 & \\
\hline Crystal size & $0.454 \times 0.222 \times 0$. & \\
\hline Theta range for data collection & 4.417 to $74.531^{\circ}$. & \\
\hline Index ranges & $-17<=\mathrm{h}<=17,-17<$ & $7,-14<=1<=14$ \\
\hline Reflections collected & 40267 & \\
\hline Independent reflections & $4745[\mathrm{R}(\mathrm{int})=0.0$ & \\
\hline Completeness to theta $=67.679^{\circ}$ & $100.0 \%$ & \\
\hline Absorption correction & Semi-empirical fro & ivalents \\
\hline Max. and min. transmission & 0.7538 and 0.6755 & \\
\hline Refinement method & Full-matrix least-s & on $\mathrm{F}^{2}$ \\
\hline Data / restraints / parameters & $4745 / 1 / 310$ & \\
\hline Goodness-of-fit on $\mathrm{F}^{2}$ & 1.025 & \\
\hline Final $R$ indices $[I>2 \operatorname{sigma}(I)]$ & $\mathrm{R} 1=0.0257, \mathrm{wR} 2$ & \\
\hline $\mathrm{R}$ indices (all data) & $\mathrm{R} 1=0.0259, \mathrm{wR} 2$ & \\
\hline Absolute structure parameter & $0.05(3)$ & \\
\hline Extinction coefficient & $0.0012(2)$ & \\
\hline Largest diff. peak and hole & 0.268 and $-0.143 \mathrm{e}$ & \\
\hline
\end{tabular}




\section{Photophysical Characterizations:}

a)

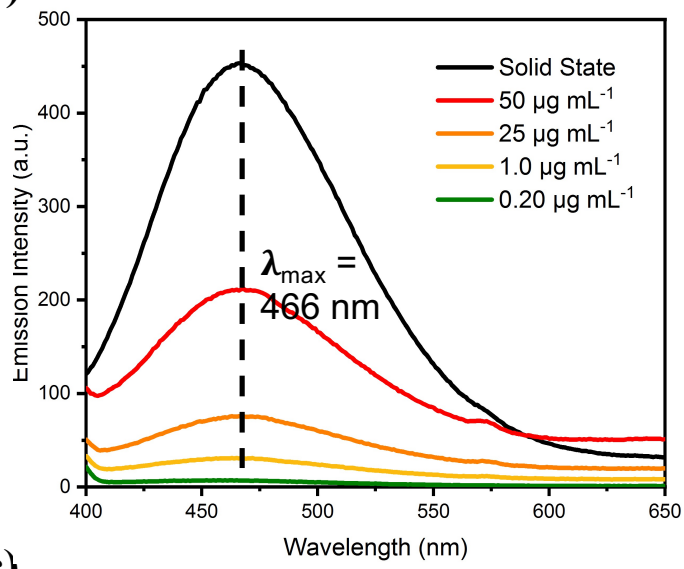

c)

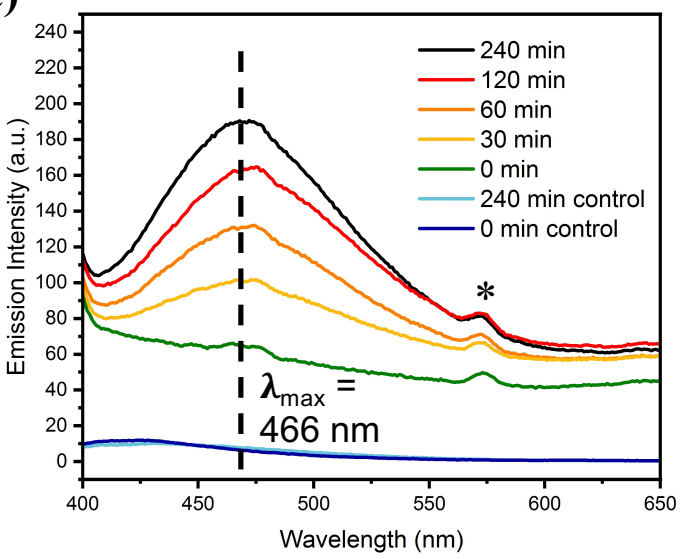

b)

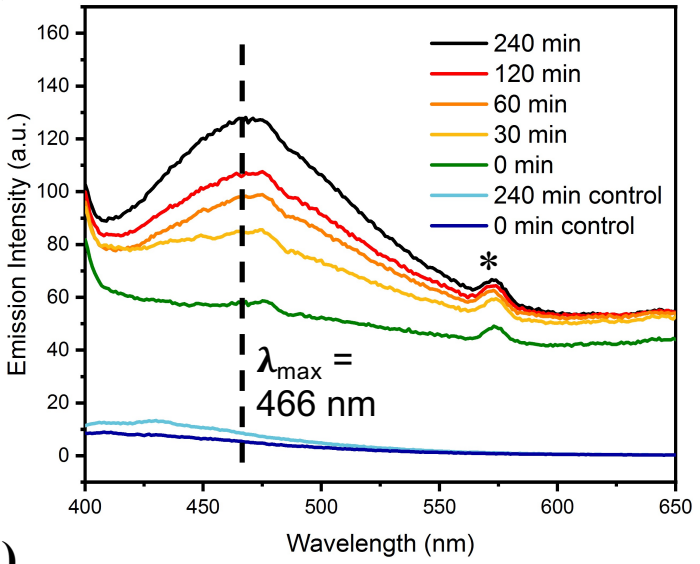

d)

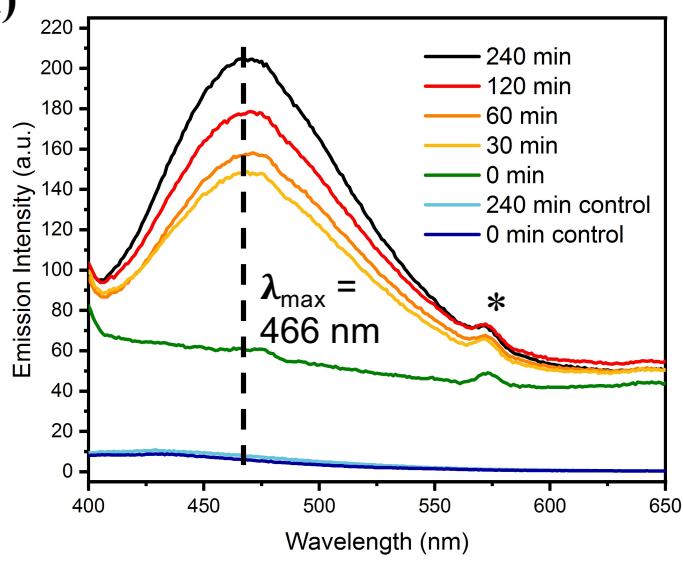

Figure S22. Photoluminescence characterization of $\mathbf{P 2}$ in THF-water mixture $\left(f_{w}=90 \%\right)$ upon sonication $\left(\lambda_{\mathrm{ex}}=350 \mathrm{~nm}\right)$. Control experiments were measured in pure THF at $50 \mu \mathrm{g}$ $\mathrm{mL}^{-1}$. (a) Fluorescence emission spectra of $\mathbf{P 2}\left(M_{\mathrm{n}}=158.8 \mathrm{kDa}\right)$ upon 240 min sonication at various concentrations. Solid state fluorescence emission spectra was measured from polymer thin film deposited on a glass substrate. (b) Fluorescence emission spectra of P2 $\left(M_{\mathrm{n}}=55.9 \mathrm{kDa}\right)$ upon sonication. (c) Fluorescence emission spectra of P2 $\left(M_{n}=110.5\right.$ $\mathrm{kDa})$ upon sonication. (d) Fluorescence emission spectra of $\mathbf{P 2}\left(M_{\mathrm{n}}=158.8 \mathrm{kDa}\right)$ upon sonication. 


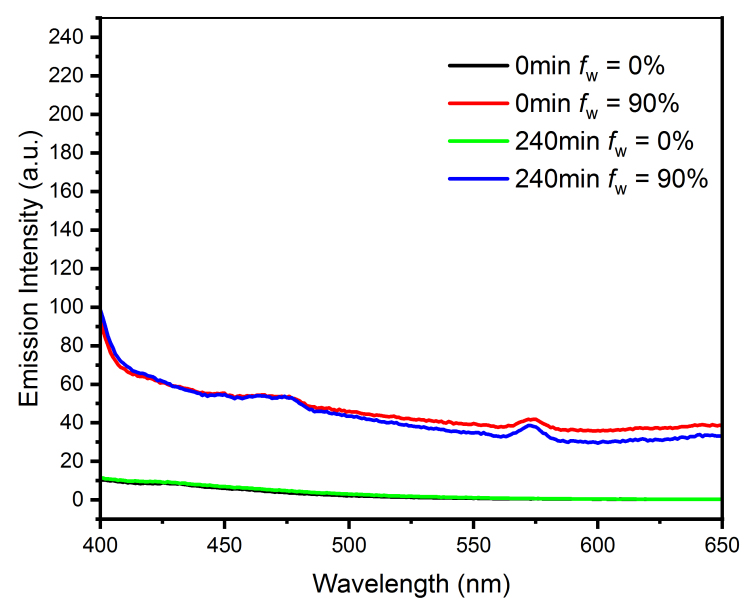

Figure S23. Fluorescent emission spectra of control P2 $\left(M_{\mathrm{n}}=6.2 \mathrm{kDa}\right)$ upon sonication

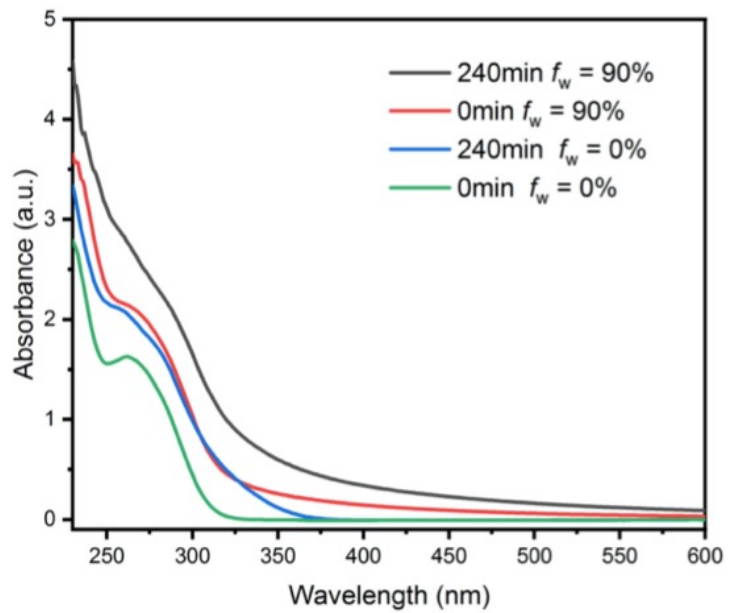

Figure S24. UV-Vis spectra of $\mathbf{P 2}\left(M_{n}=158.8 \mathrm{kDa}\right)$ before and after 240 min sonication in THF or THF and water mixtures at $0.10 \mathrm{mg} \mathrm{mL}^{-1}$

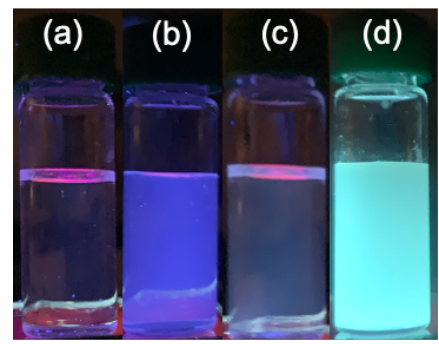

Figure S25. Aggregtion-Induced Emission turn on of P2 upon sonication. Photos taken under 365nm UV. (a) P2 in pure THF before sonication. (b) P2 suspension before sonication in THF and water mixture $\left(f_{w}=90 \%\right)$ The purple color is from light scattering. (c) SP2 in pure THF upon 240 min sonication. (d) SP2 suspension generated upon 240 min sonication followed by the addition of water into THF $\left(f_{w}=90 \%\right)$ upon $240 \mathrm{~min}$ sonication. 


\section{General GC-TCD CO detection procedure:}

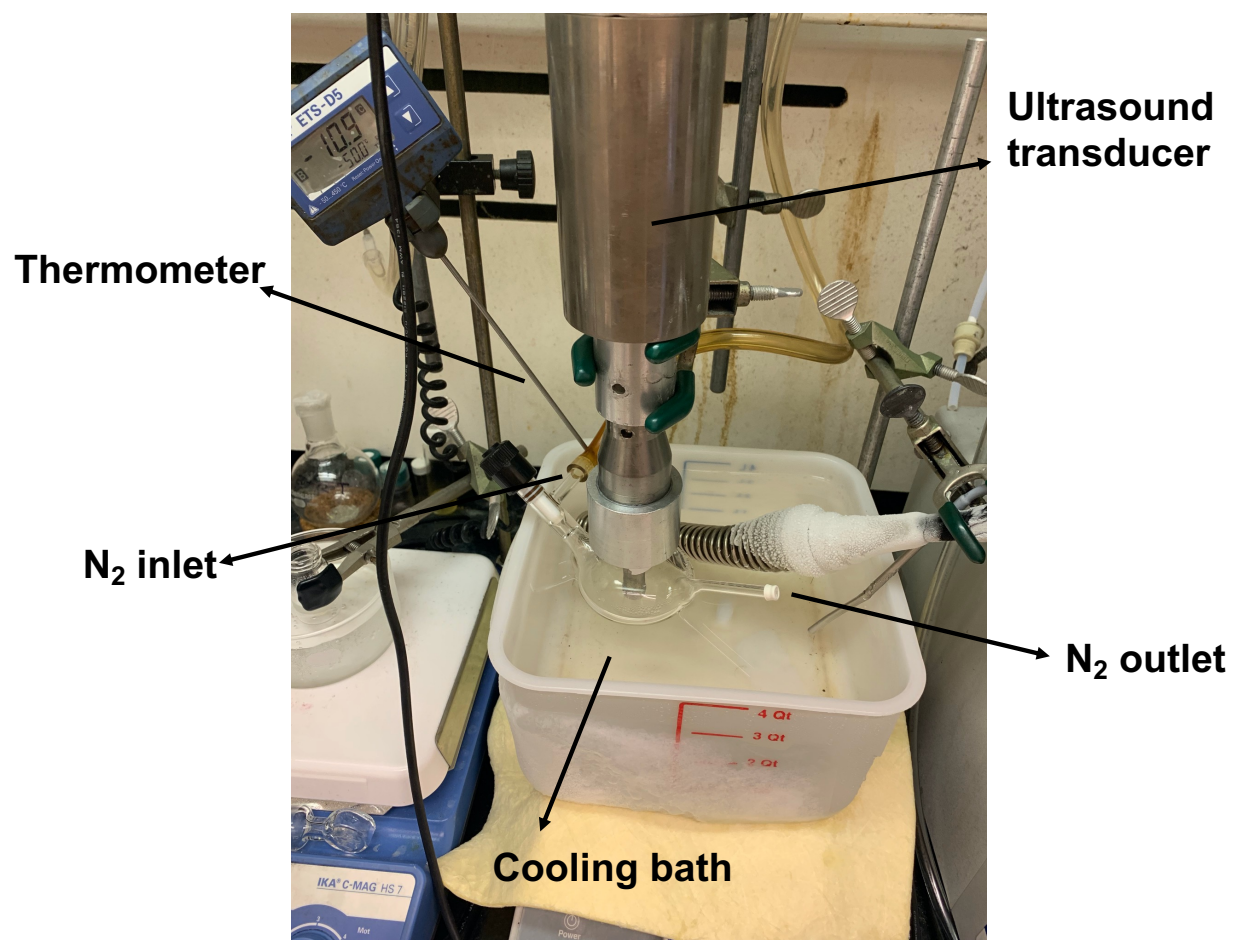

To an oven-dried two arm cell, $35 \mathrm{~mL}$ of a $1.8 \mathrm{mg} \cdot \mathrm{mL}^{-1}$ solution of $\mathbf{P} 2$ in THF was added, and the solution was sparged with $\mathrm{N}_{2}$ for $30 \mathrm{~min}$ at $-10{ }^{\circ} \mathrm{C}$. Then the $\mathrm{N}_{2}$ flow was stopped and the system was closed before the sonication was initiated. An air-tight Hamilton SampleLock syringe was used to extract $300 \mu \mathrm{L}$ of the gas headspace, which was then injected into $\mathrm{GC}$ at predetermined times.

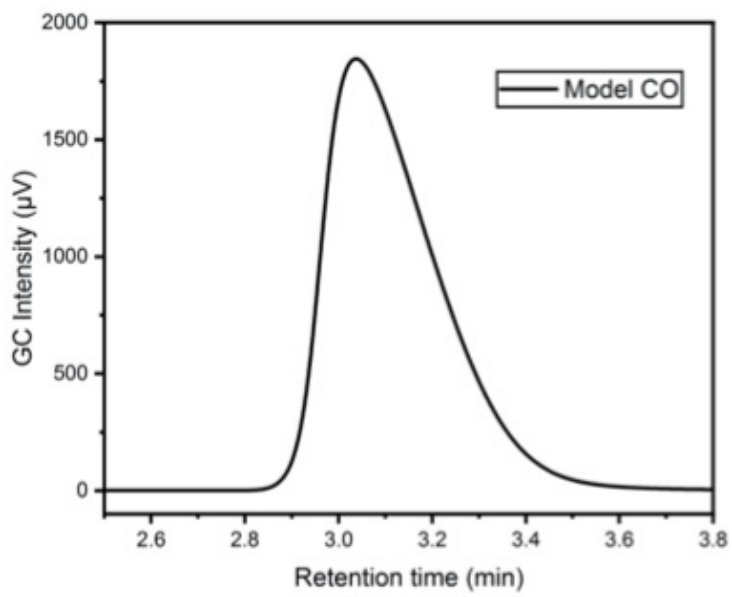

Figure S26. GC-TCD trace of model CO gas. CO gas was prepared from reported procedures. $^{5}$ 

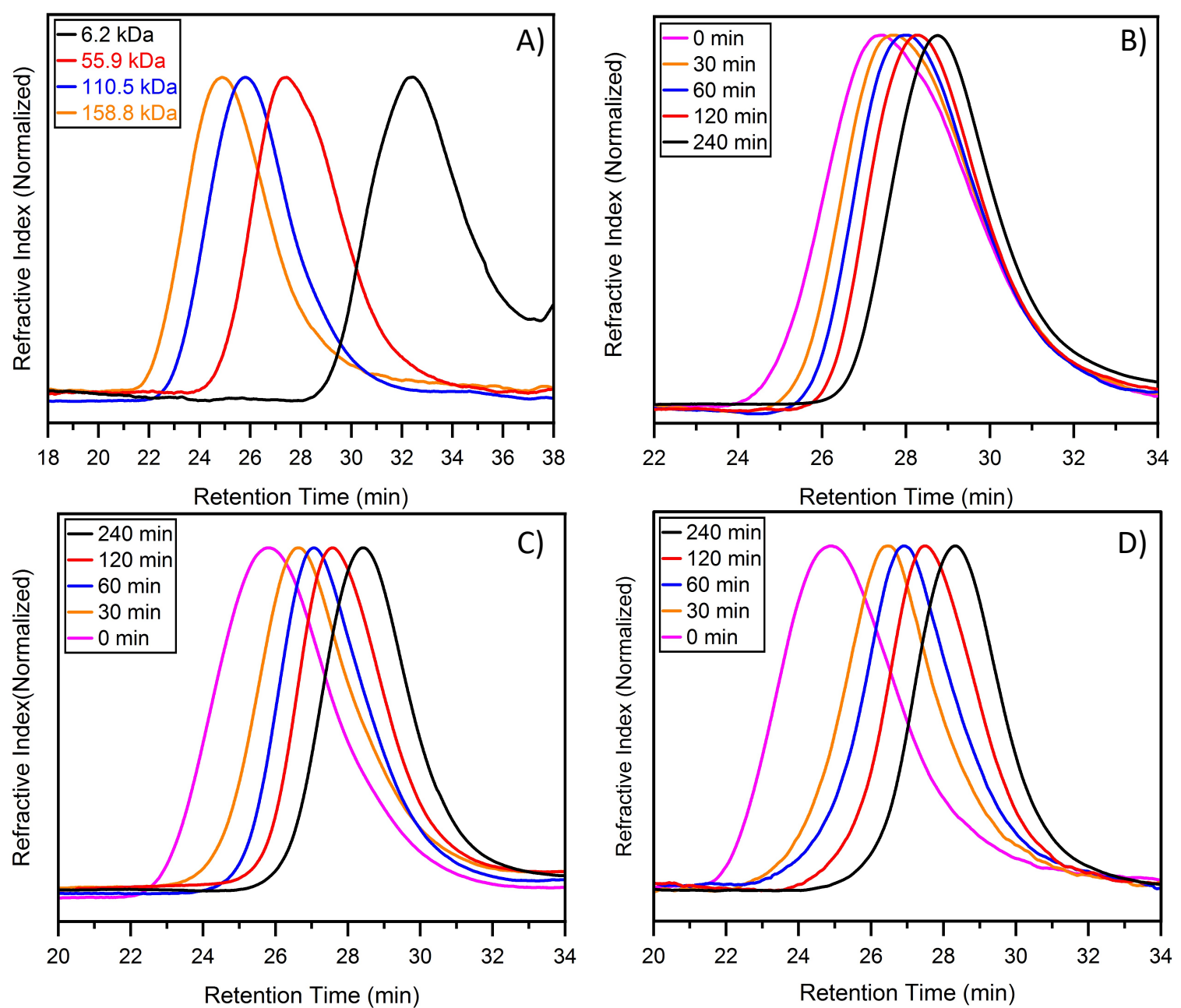

Figure S27. SEC traces of $\mathbf{P 2}$ and SP2 in THF. A) All $\mathbf{P 2}$ used for CO release kinetic trials and low molecular weight P2 control. B) Sonication trial of $55.9 \mathrm{kDa}$ P2 C) Sonication trial of $110.5 \mathrm{kDa} \mathbf{P 2} \mathrm{D})$ Sonication trial of $158.8 \mathrm{kDa} \mathbf{P 2}$. 


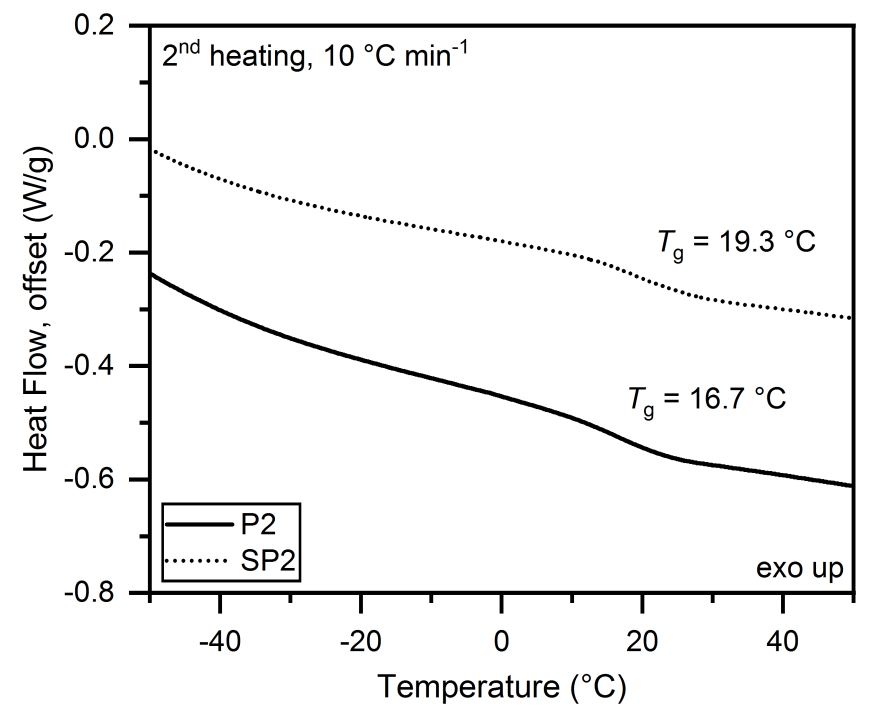

Figure S28. DSC of P2 $\left(M_{\mathrm{n}}=129.7 \mathrm{kDa}\right)$ and SP2 $\left(M_{\mathrm{n}}=72.5 \mathrm{kDa}, \Phi=38.1 \%\right)$. Glass transition temperatures $\left(T_{\mathrm{g}}\right)$ were taken from the second heating curve with a heating rate of $10^{\circ} \mathrm{C} \cdot \mathrm{min}^{-1}$.

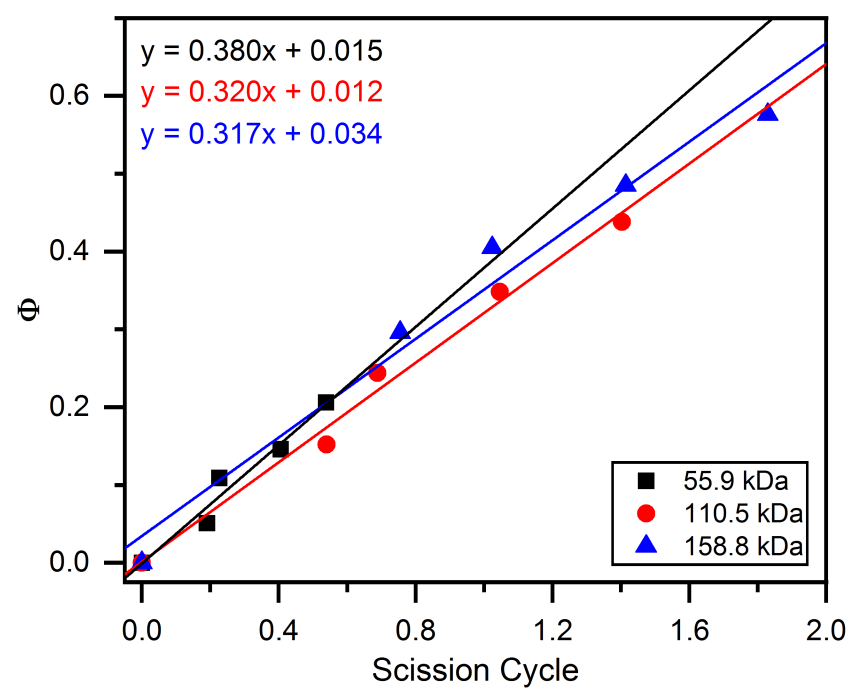

Figure S29. P2 activation vs. scission cycle at different molecular weights. Decrease in slope with increasing molecular weight is in good accord with prior reports. ${ }^{6,7}$ 


\section{Calculations}

Amount of $C O$ released per chain for $\boldsymbol{P 2}$

(158.8 kDa, 47.1\% NEO incorporation, $\Phi=56.2 \%)$ :

Weight percent of NEO in copolymer $=$

$$
\begin{gathered}
\frac{\left(456.24(\mathrm{NEO}) \mathrm{g} \cdot \mathrm{mol}^{-1} * 0.471\right)}{\left(456.24 \mathrm{~g} \cdot \mathrm{mol}^{-1} * 0.471\right)+\left(110.2\left(\mathrm{COE}_{\mathrm{comonomer}}\right) \mathrm{g} \cdot \mathrm{mol}^{-1} * 0.529\right)} \\
* 100=78.7 \% \\
\quad \mathrm{DP} \text { NEO }=\frac{\left(158,800 \mathrm{~g} \cdot \mathrm{mol}^{-1} * 0.787\right)}{456.24 \mathrm{~g} \cdot \mathrm{mol}^{-1}}=274 \\
\text { Activation per chain }=274 * 0.562=\mathbf{1 5 4}
\end{gathered}
$$

Expected amount of CO released (TGA) for P2 (129.7 kDa, 43.2\% NEO incorporation) and $\boldsymbol{S P 2}(\Phi=38.1 \%)$ :

Weight percent of NEO in copolymer $=$

$$
\begin{gathered}
\left(456.24(\mathrm{NEO}) \mathrm{g} \cdot \mathrm{mol}^{-1} * 0.432\right) \\
\left(456.24 \mathrm{~g} \cdot \mathrm{mol}^{-1} * 0.432\right)+\left(110.2(\mathrm{COE} \text { comonomer }) \mathrm{g} \cdot \mathrm{mol}^{-1} * 0.568\right) \\
* 100=75.9 \%
\end{gathered}
$$

Weight percent of NEO in copolymer after 240 min sonication $=$

$$
\begin{aligned}
& \frac{\left(456.24(\mathrm{NEO}) \mathrm{g} \cdot \mathrm{mol}^{-1} * 0.432 * 0.619\right)}{\left(456.24 \mathrm{~g} \cdot \mathrm{mol}^{-1} * 0.432 * 0.619\right)+} * 100=47.8 \% \\
& \left(428.23(\text { activated } \mathrm{NEO}) \mathrm{g} \cdot \mathrm{mol}^{-1} * 0.432 * 0.381\right)+ \\
& \left(110.2(\mathrm{COE} \text { comonomer }) \mathrm{g} \cdot \mathrm{mol}^{-1} * 0.568\right)
\end{aligned}
$$

For $1 \mathrm{~g}$ of $\mathrm{P} 2,0.759 \mathrm{~g}$ is attributed to $\mathrm{NEO}$. $\mathrm{FW}_{\mathrm{CO}}=28.01 \mathrm{~g} \bullet \mathrm{mol}^{-1}$ which is $6.14 \%$ the mass of NEO. Therefore predicted weight loss $\%=$

$$
0.759 * 6.14 \%=\mathbf{4 . 7 \%}
$$

For SP2, only $0.478 \mathrm{~g}$ is attributed to NEO. Therefore predicted weight loss $\%=$

$$
0.478 * 6.14 \%=\mathbf{2 . 9 \%}
$$




\section{Scission Cycle: ${ }^{6}$ \\ $S C=\ln \left(\mathrm{M}_{0}\right)-\ln \left(\mathrm{M}_{\mathrm{t}}\right) / \ln (2)$}

Table S3. Characterization of P2 upon sonication

\begin{tabular}{|c|c|c|c|c|c|}
\hline Time (min) & $M_{\mathrm{n}}(\mathrm{kDa})^{\mathrm{a})}$ & NEO (\%) & $\bigoplus^{a)}$ & SC & $\Phi(\%)^{b)}$ \\
\hline 0 & 55.9 & 44.1 & 1.6 & - & - \\
\hline 30 & 49 & - & 1.5 & 0.19 & 5.1 \\
\hline 60 & 47.8 & - & 1.4 & 0.23 & 10.9 \\
\hline 120 & 42.2 & - & 1.4 & 0.41 & 14.6 \\
\hline 240 & 38.5 & - & 1.3 & 0.54 & 20.6 \\
\hline Time $(\min )$ & $M_{\mathrm{n}}(\mathrm{kDa})^{\mathrm{a})}$ & NEO (\%) & $\theta^{a)}$ & SC & $\Phi(\%)^{b)}$ \\
\hline 0 & 110.5 & 47.7 & 1.7 & - & - \\
\hline 30 & 76 & - & 1.6 & 0.54 & 15.2 \\
\hline 60 & 68.6 & - & 1.4 & 0.69 & 24.4 \\
\hline 120 & 53.5 & - & 1.4 & 1.05 & 34.8 \\
\hline 240 & 41.8 & - & 1.3 & 1.40 & 43.8 \\
\hline Time (min) & $M_{\mathrm{n}}(\mathrm{kDa})^{\mathrm{a})}$ & NEO (\%) & $\theta^{a)}$ & SC & $\Phi(\%)^{b)}$ \\
\hline 0 & 158.8 & 47.1 & 1.7 & - & - \\
\hline 30 & 94.1 & - & 1.6 & 0.75 & 29.6 \\
\hline 60 & 78.1 & - & 1.5 & 1.02 & 40.5 \\
\hline 120 & 59.6 & - & 1.4 & 1.41 & 48.5 \\
\hline 240 & 44.7 & - & 1.4 & 1.83 & 57.6 \\
\hline
\end{tabular}

a) $M_{\mathrm{n}}$ and $Ð$ determined by SEC (RI) analysis in THF compared to a $12 \mathrm{pt}$. conventional calibration using narrow dispersity polystyrene standards. b) activation (\%) determined by ${ }^{1} \mathrm{H}-\mathrm{NMR}$ analysis $\left(\mathrm{CDCl}_{3}\right)$. 


\section{NMR Spectra}

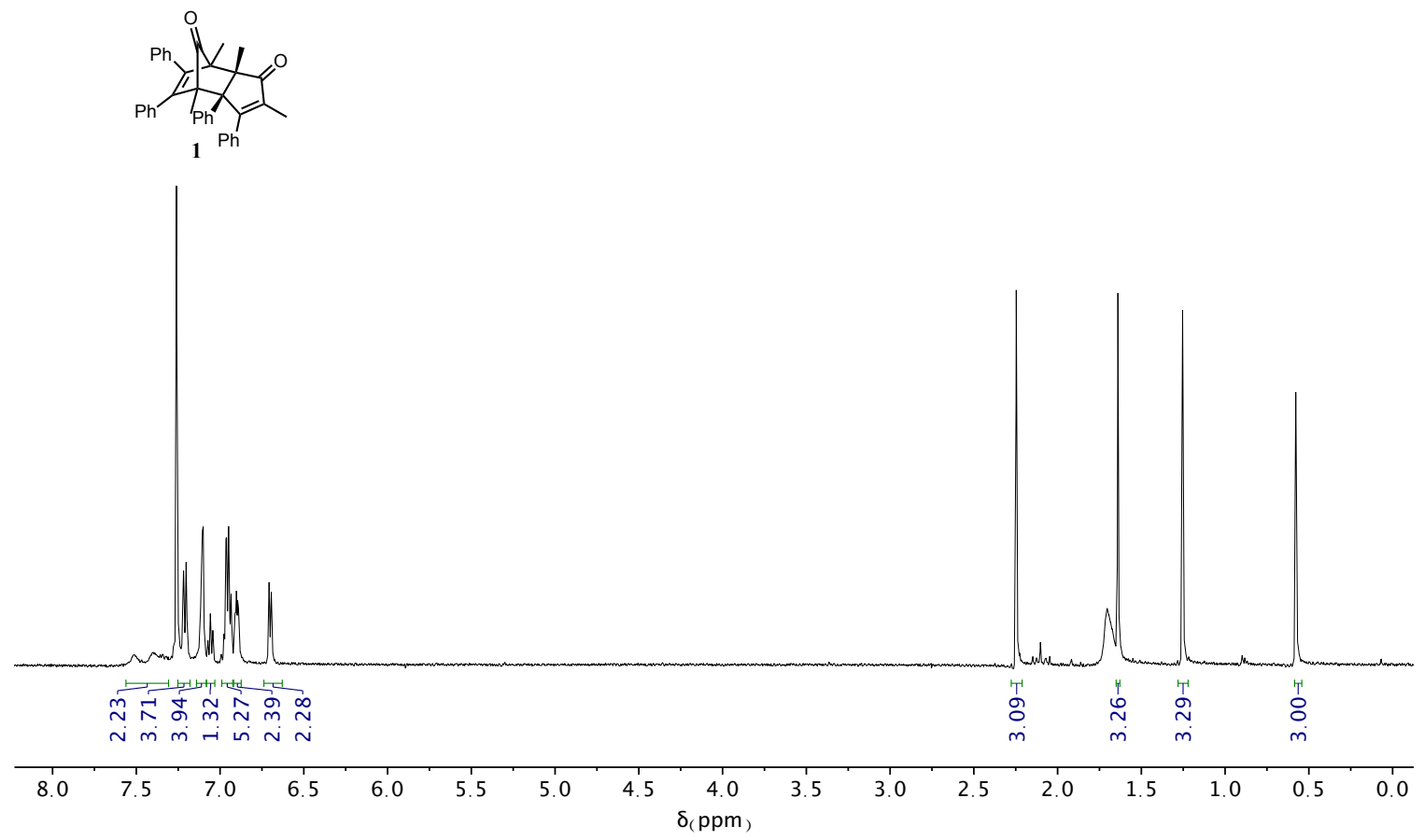

Figure S30. ${ }^{1} \mathrm{H} \mathrm{NMR}$ spectrum of $1\left(500 \mathrm{MHz}, \mathrm{CDCl}_{3}\right)$.

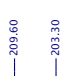

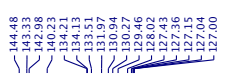

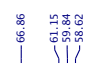

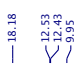
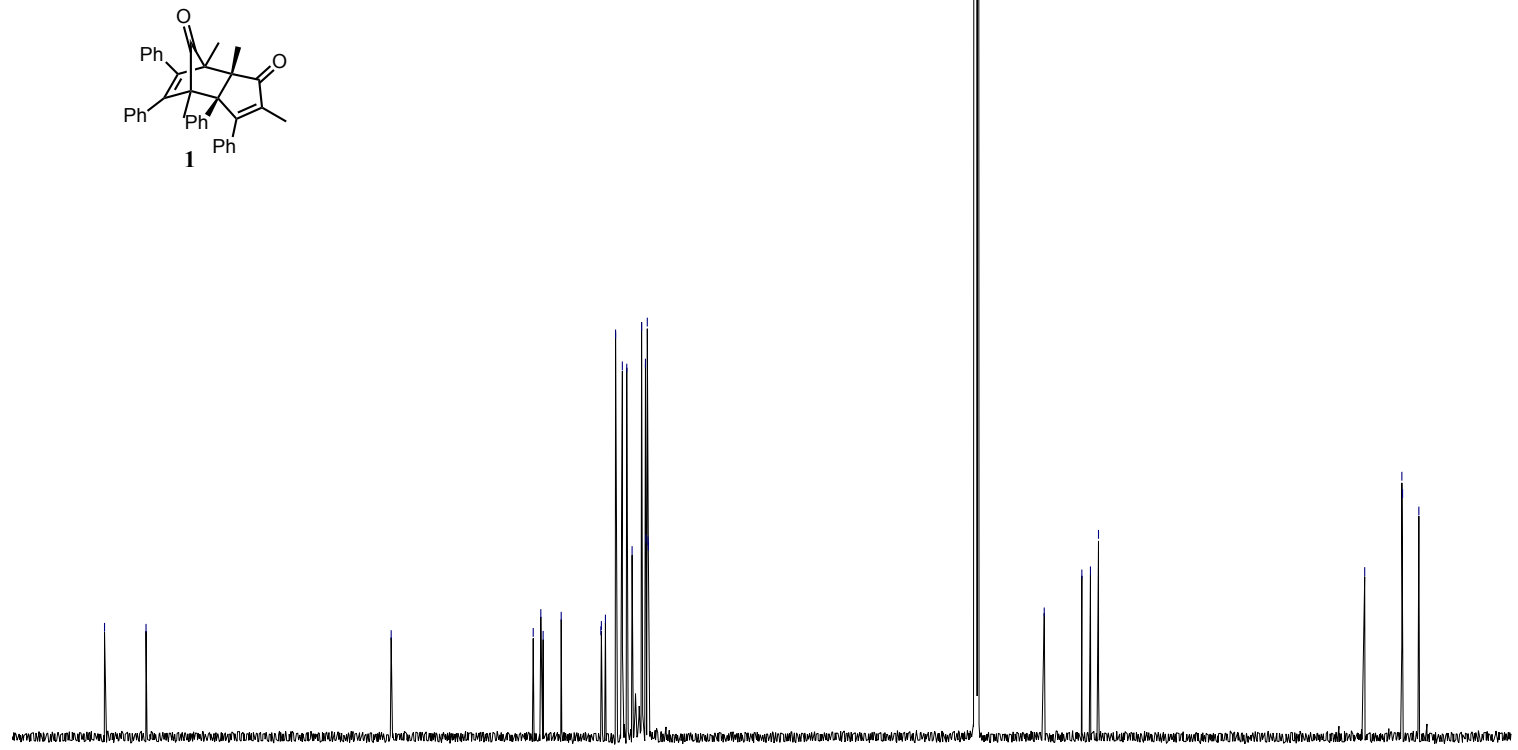

\begin{tabular}{llllllllllllllllllllllllllll}
\hline 220 & 210 & 200 & 190 & 180 & 170 & 160 & 150 & 140 & 130 & 120 & 110 & 100 & 90 & 80 & 70 & 60 & 50 & 40 & 30 & 20 & 10 & 0 \\
$\delta(\mathrm{pm})$ & & & & & & & & & & &
\end{tabular}

Figure S31. ${ }^{13} \mathrm{C}$ NMR spectrum of $1\left(126 \mathrm{MHz}, \mathrm{CDCl}_{3}\right)$. 

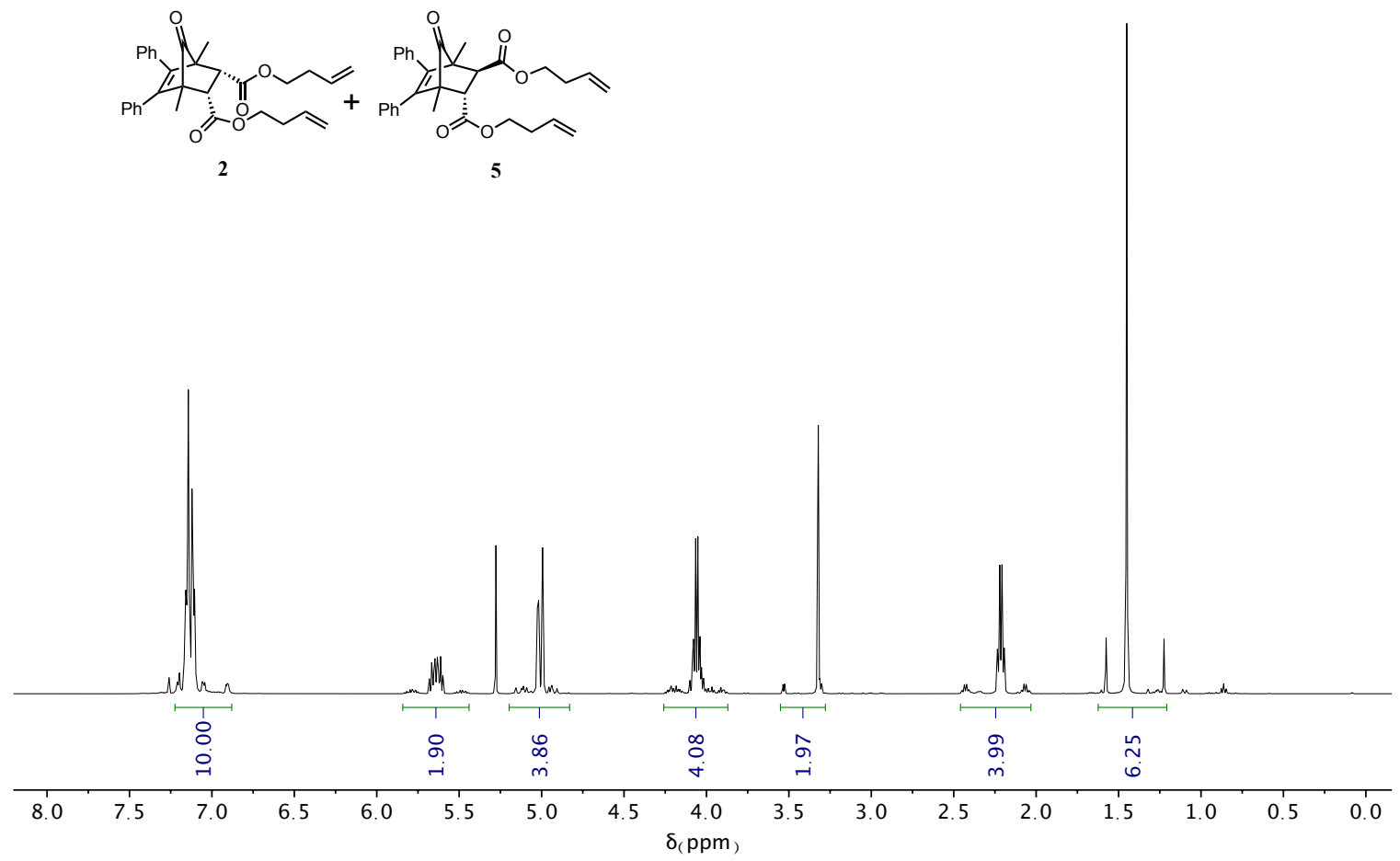

Figure S32. ${ }^{1} \mathrm{H}$ NMR spectrum of the mixture 2 and $5\left(500 \mathrm{MHz}, \mathrm{CDCl}_{3}\right)$.

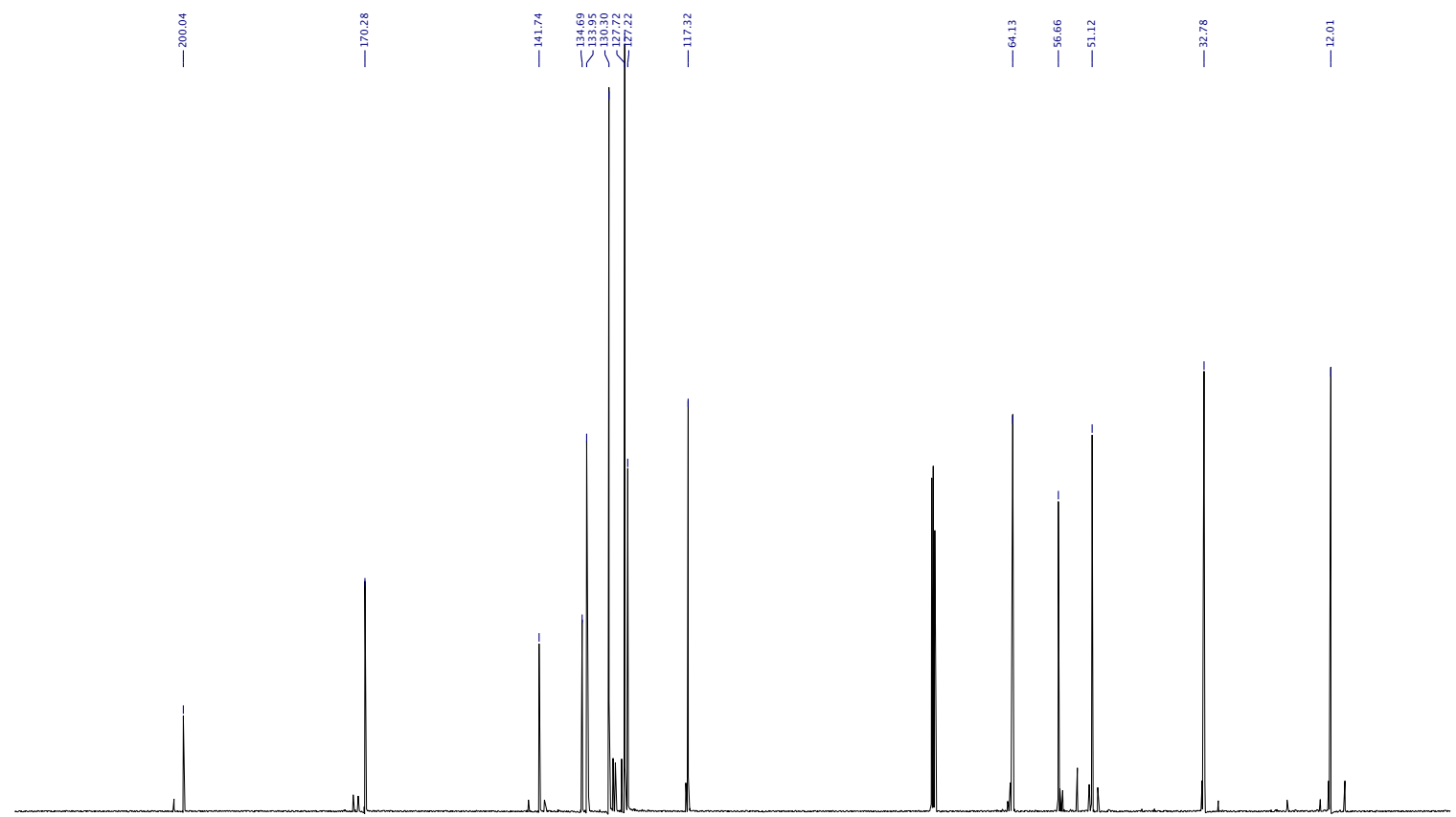

$\begin{array}{lllllllllllllllllllllllllllll}220 & 210 & 200 & 190 & 180 & 170 & 160 & 150 & 140 & 130 & 120 & 110 & 100 & 90 & 80 & 70 & 60 & 50 & 40 & 30 & 20 & 10 & 0 & \delta_{(\mathrm{ppm})}\end{array}$

Figure S33. ${ }^{13} \mathrm{C}$ NMR spectrum of the mixture 2 and $5\left(126 \mathrm{MHz}, \mathrm{CDCl}_{3}\right)$. 


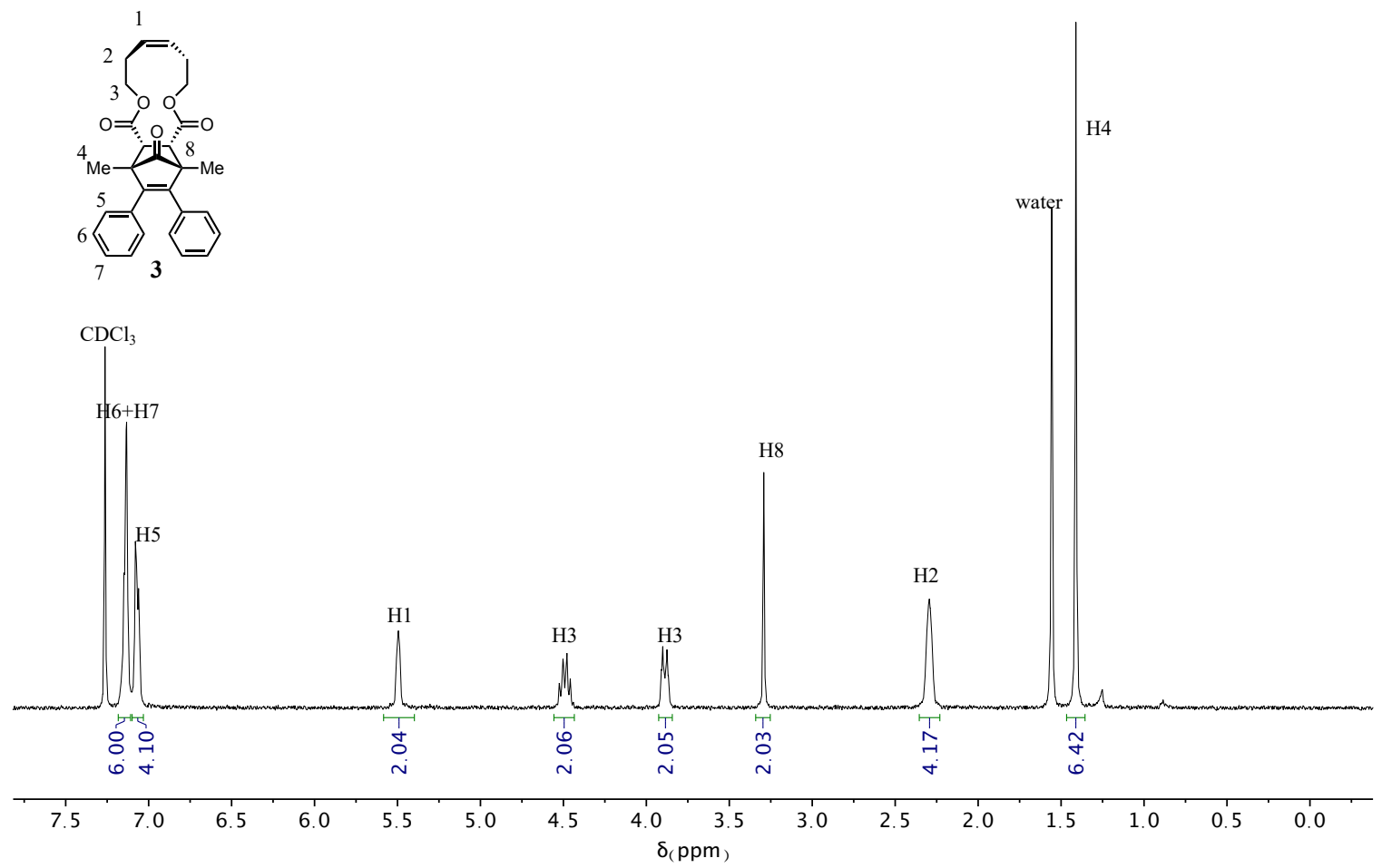

Figure S34. ${ }^{1} \mathrm{H}$ NMR spectrum of $\mathbf{3}\left(500 \mathrm{MHz}, \mathrm{CDCl}_{3}\right)$.

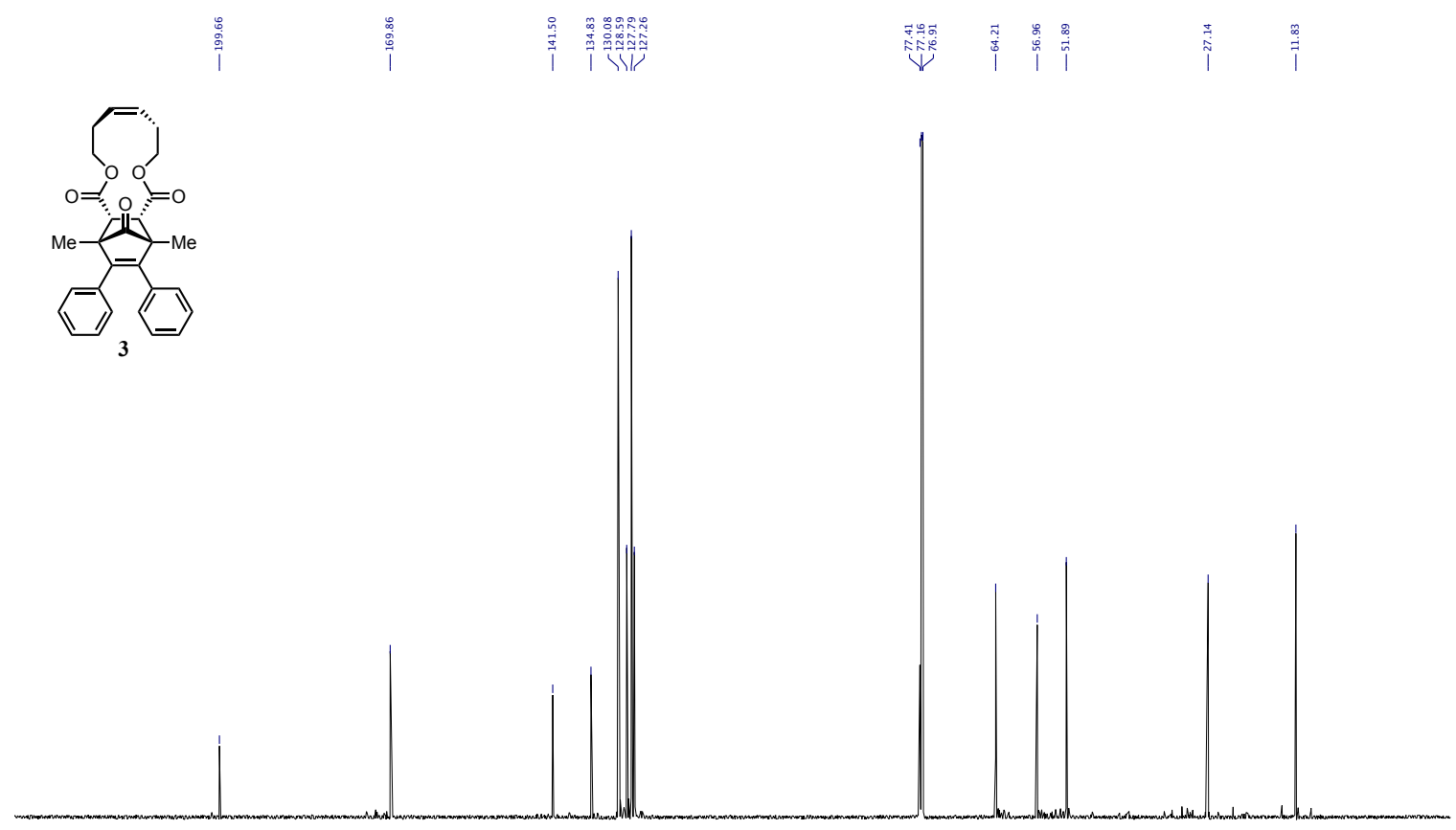

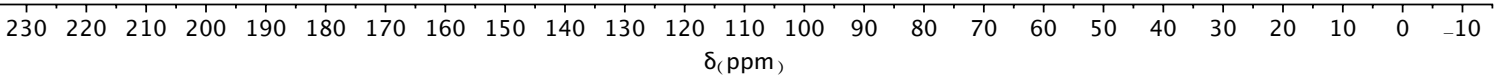
Figure S35. ${ }^{13} \mathrm{C}$ NMR spectrum of the $3\left(126 \mathrm{MHz}, \mathrm{CDCl}_{3}\right)$. 


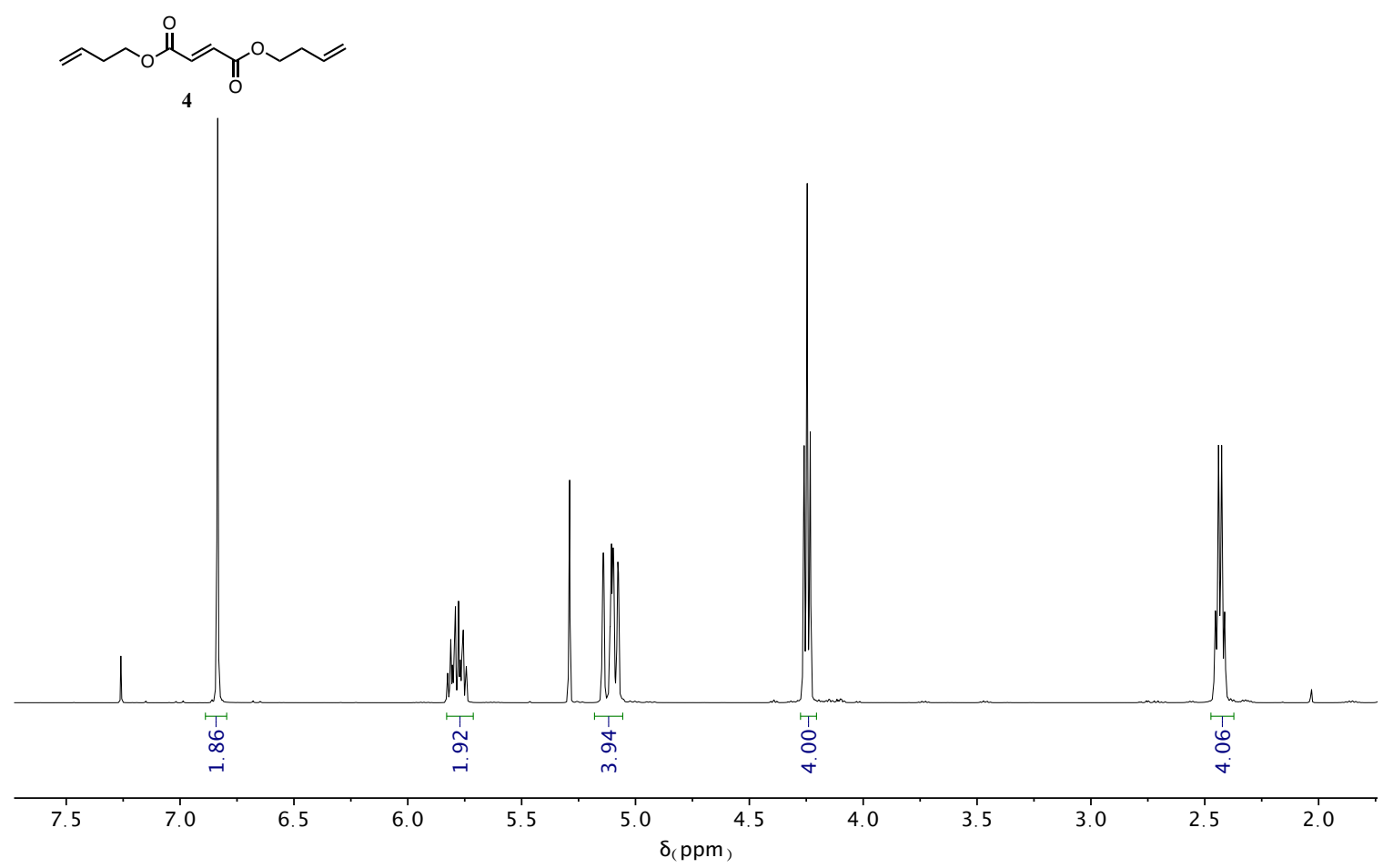

Figure S36. ${ }^{1} \mathrm{H}$ NMR spectrum of $4\left(500 \mathrm{MHz}, \mathrm{CDCl}_{3}\right)$.
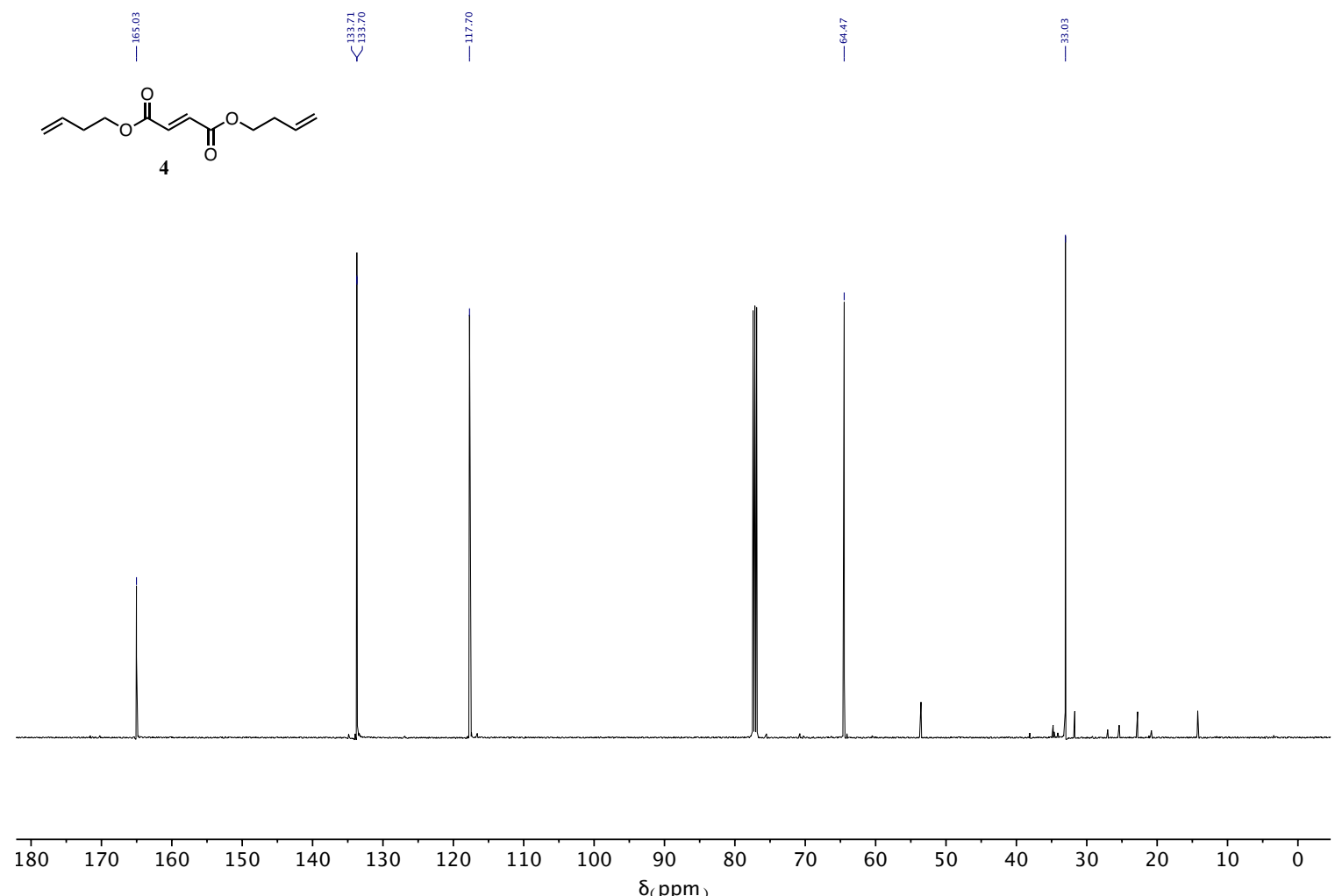

Figure S37. ${ }^{13} \mathrm{C}$ NMR spectrum of $4\left(126 \mathrm{MHz}, \mathrm{CDCl}_{3}\right)$. 

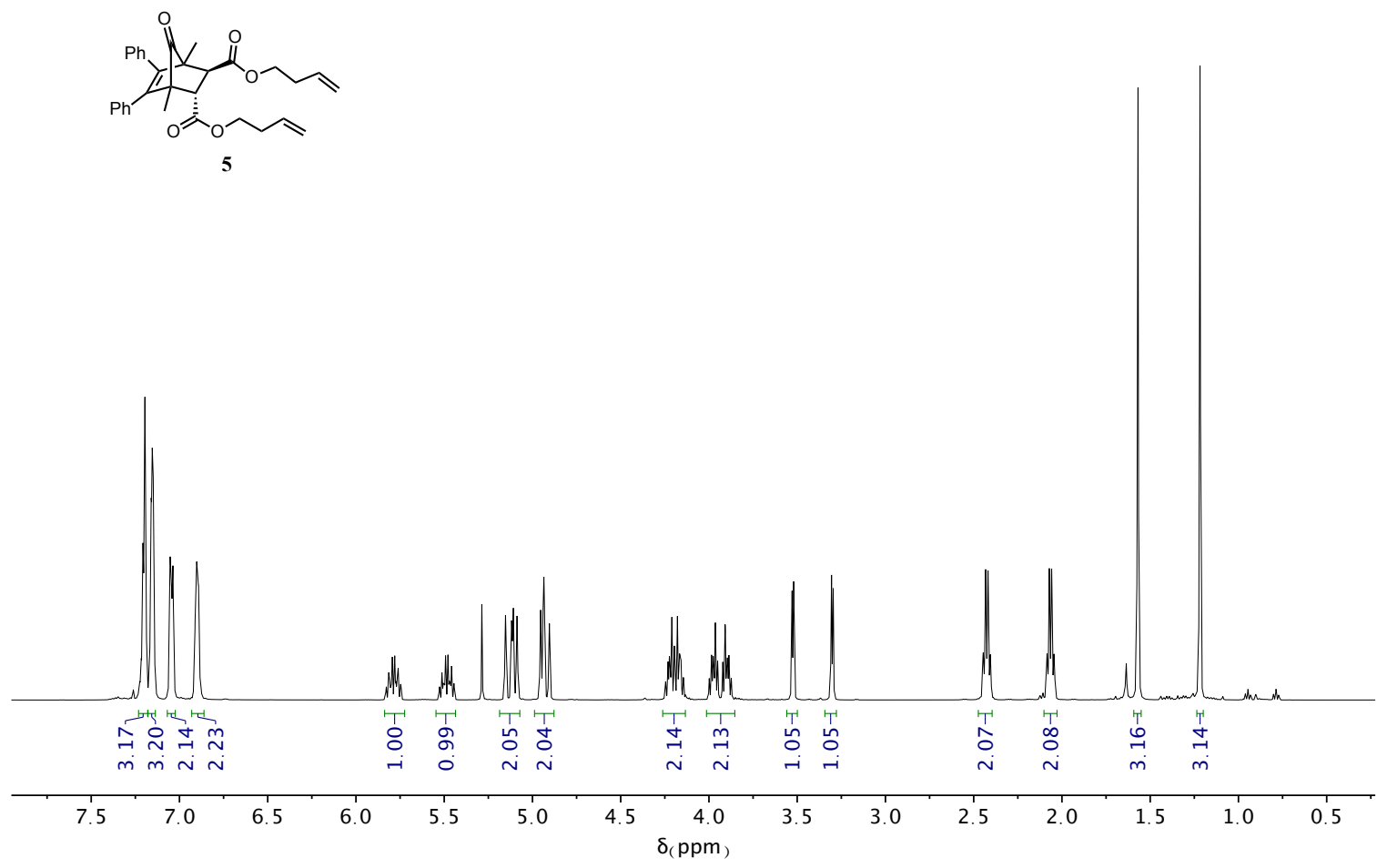

Figure S38. ${ }^{1} \mathrm{H}$ NMR spectrum of $5\left(500 \mathrm{MHz}, \mathrm{CDCl}_{3}\right)$.
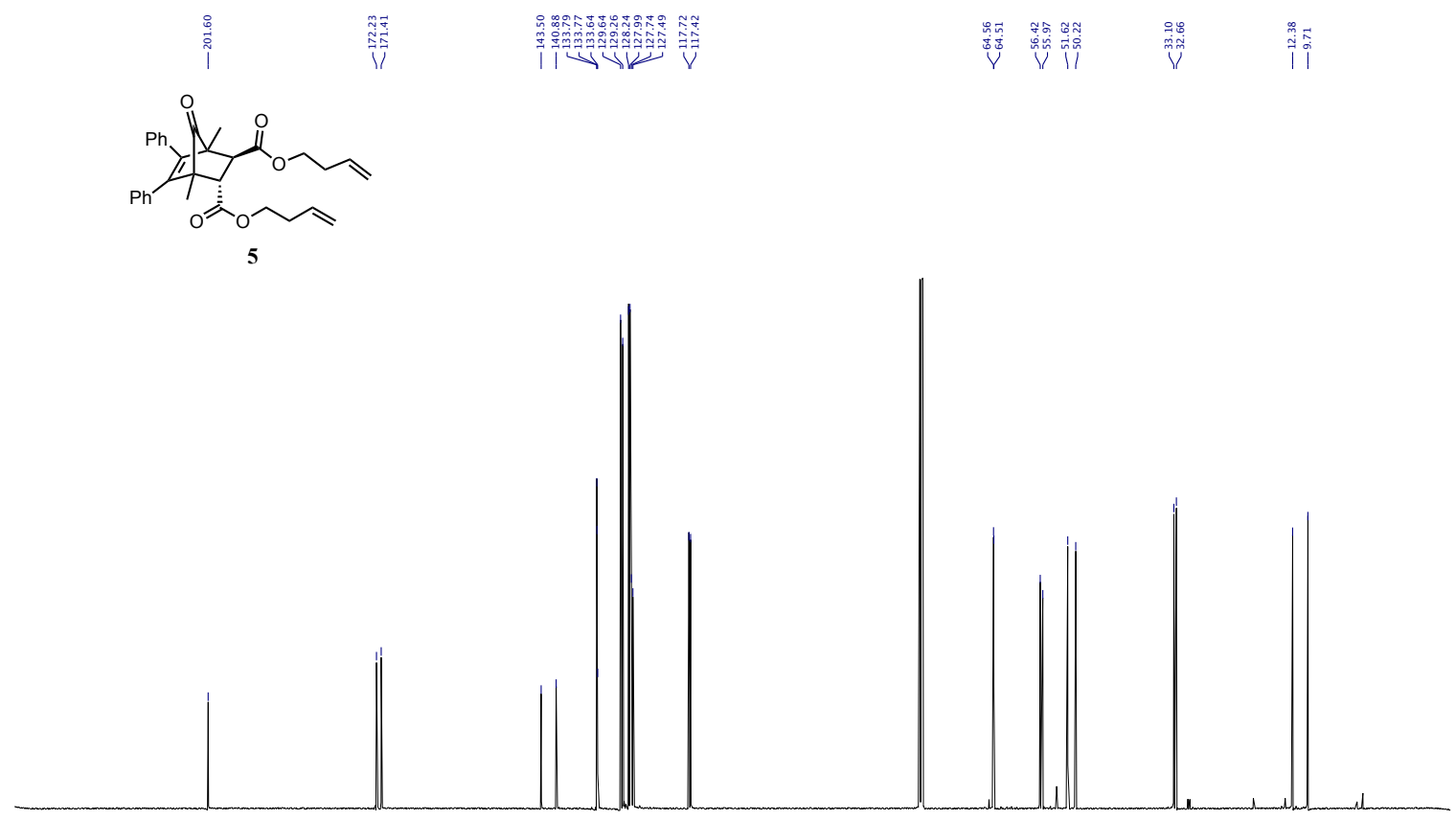

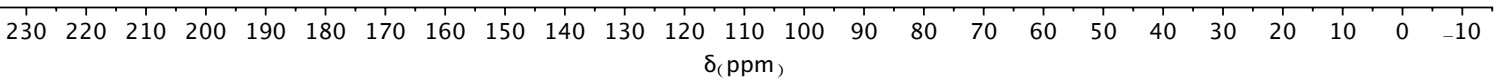

Figure S39. ${ }^{13} \mathrm{C}$ NMR spectrum of $5\left(126 \mathrm{MHz} \mathrm{CDCl}_{3}\right)$. 

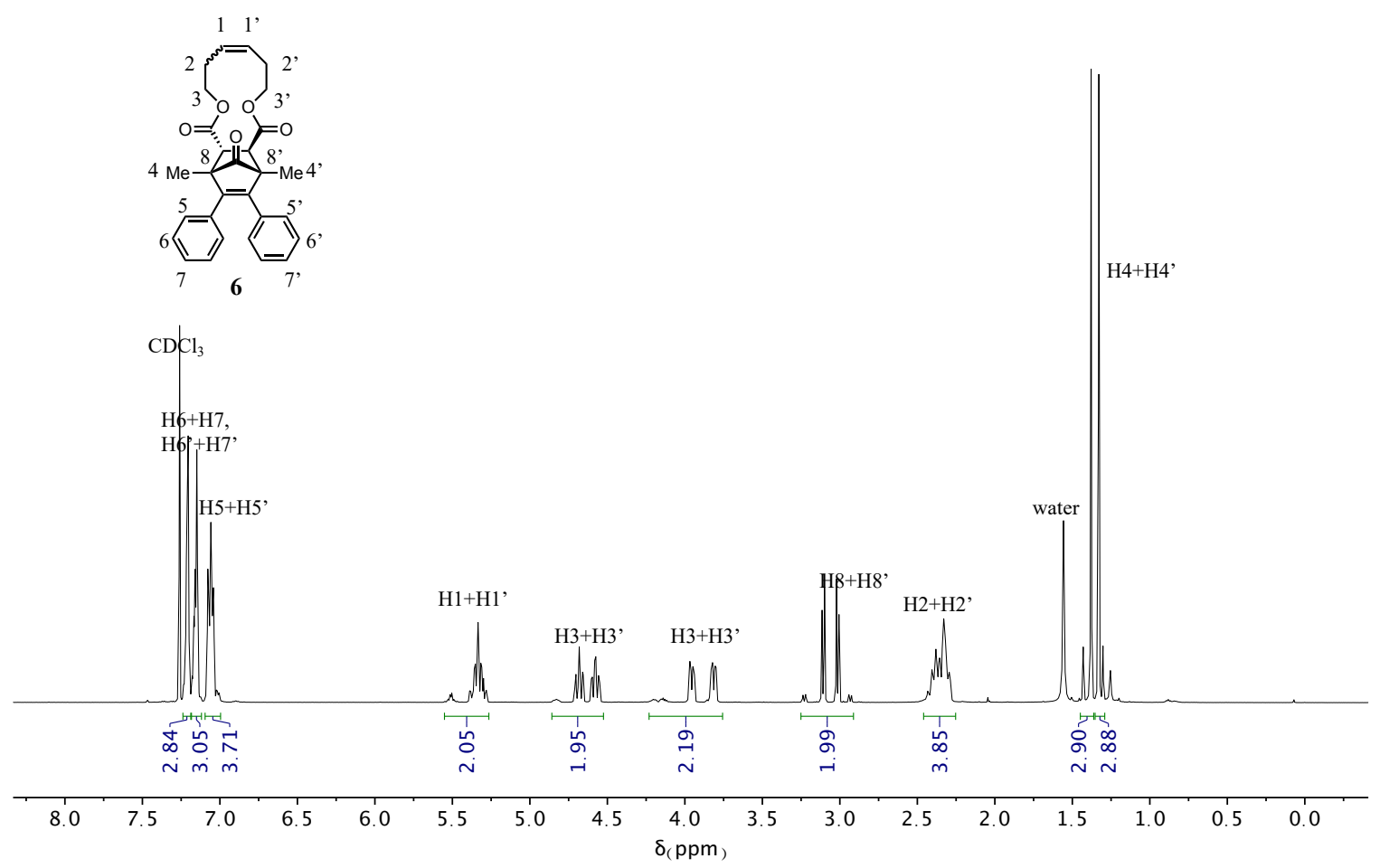

Figure S40. ${ }^{1} \mathrm{H} \mathrm{NMR}$ spectrum of $6\left(500 \mathrm{MHz}, \mathrm{CDCl}_{3}\right)$.
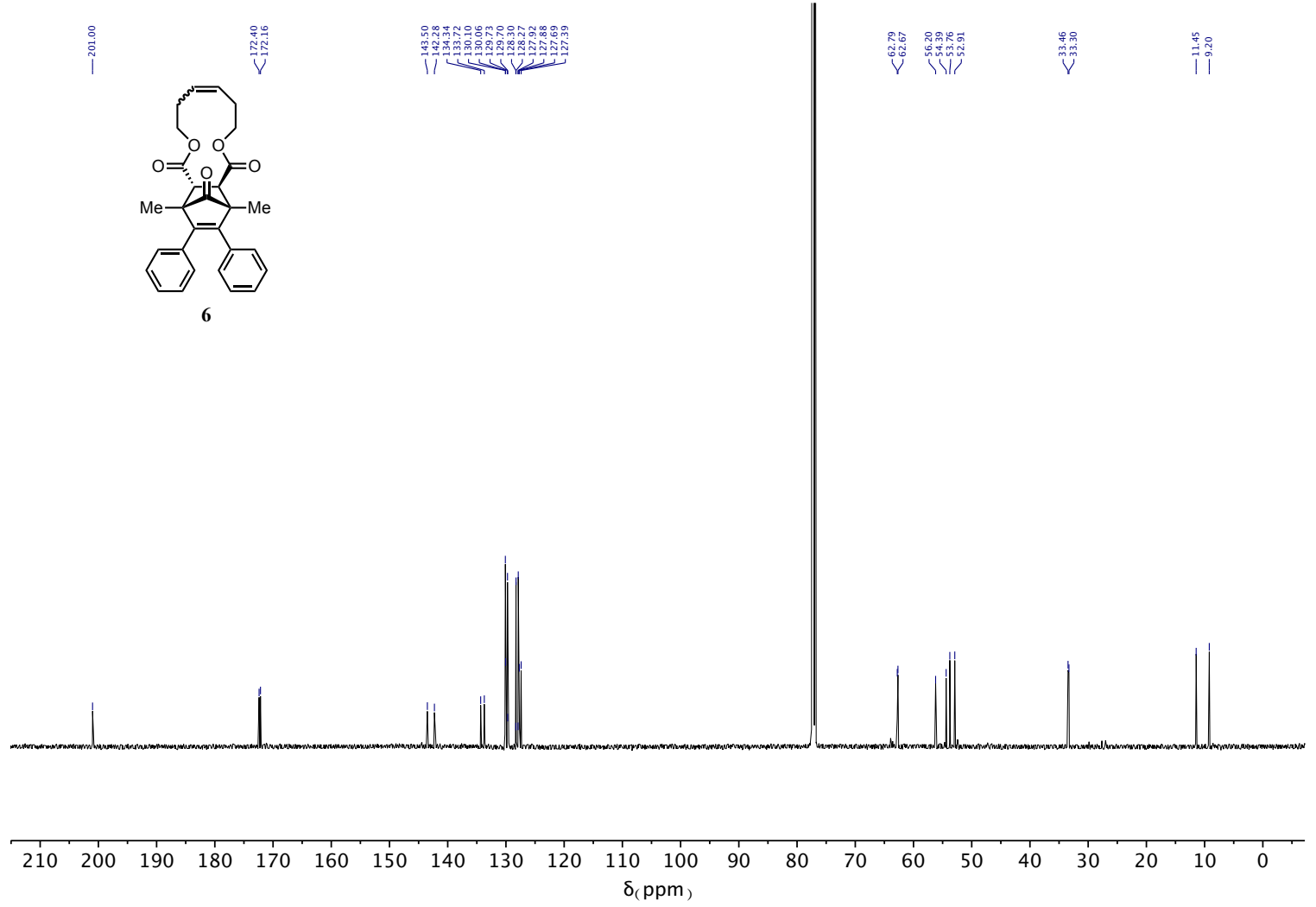

Figure S41. ${ }^{13} \mathrm{C}$ NMR spectrum of $6\left(126 \mathrm{MHz}, \mathrm{CDCl}_{3}\right)$. 


\section{Optimized Geometry Coordinates}

\begin{tabular}{|c|c|c|c|}
\hline & 0.000218383 & 0.00025998 & 0.000539047 \\
\hline & -0.000375899 & -0.00035617 & -0.000371134 \\
\hline$y$ & -0.000256493 & -0.000347245 & -0.000069266 \\
\hline & 0.000374249 & 0.000181473 & 0.000049327 \\
\hline$y$ & -0.000029642 & 0.000028592 & -0.000417021 \\
\hline $\mathrm{C}$ & -0.000057735 & 0.000155732 & 0.000405016 \\
\hline $\mathrm{C}$ & -0.000305227 & -0.000149396 & 0.000033479 \\
\hline C & 0.000118833 & 0.000159472 & 0.000028745 \\
\hline 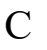 & -0.000071383 & -0.000041534 & 0.000012218 \\
\hline $\mathrm{C}$ & 0.000000323 & -0.00 & -0.000020357 \\
\hline $\mathrm{C}$ & -0.000041118 & 0.000050791 & 0.000018745 \\
\hline $\mathrm{C}$ & 0.000109433 & 0.0000 & -0.0000 \\
\hline $\mathrm{C}$ & 0.000029058 & -0.000069657 & -0.000186563 \\
\hline C & -0.000016081 & -0.00 & 0.000081036 \\
\hline $\mathrm{C}$ & -0.000006881 & 0.000045383 & 0.00002732 \\
\hline C & 0.000017167 & -0.00 & 0.00 \\
\hline $\mathrm{C}$ & 0.00002 & 0.00 & $-0 .($ \\
\hline $\mathrm{C}$ & -0.000039078 & -0.00 & 0.00 \\
\hline $\mathrm{C}$ & 0.00000 & 0.00 & 0.0 \\
\hline C & 0.000015873 & -0.000 & -0.000 \\
\hline $\mathrm{C}$ & 0.000156643 & 0.00 & -0.00 \\
\hline $\mathrm{O}$ & -0.000017395 & 0.000 & 0.00 \\
\hline $\mathrm{O}$ & -0.000062365 & -0.0000 & 0.00 \\
\hline $\mathrm{C}$ & 0.000051118 & -0.00000353 & 0892 \\
\hline $\mathrm{C}$ & & 0.000183537 & \\
\hline $\mathrm{O}$ & -0.00010 & -0.0 & -0. \\
\hline $\mathrm{O}$ & -0.000036804 & 0.000005018 & 0.00 \\
\hline $\mathrm{C}$ & 0.0000 & 0.00 & -0.0 \\
\hline $\mathrm{H}$ & 0.000003559 & 0.000 & 0.00 \\
\hline $\mathrm{H}$ & -0.000023476 & 0.00001457 & -0.000 \\
\hline $\mathrm{H}$ & 0.000008893 & 0.000022029 & 0.000 \\
\hline $\mathrm{H}$ & 0.000014522 & 0.000012116 & 0.000006291 \\
\hline $\mathrm{H}$ & 0.000009652 & -0.000016229 & -0.000010882 \\
\hline $\mathrm{H}$ & & -0.000022229 & -0.000001453 \\
\hline $\mathrm{H}$ & 0.00003703 & -0.000006149 & 0.000015097 \\
\hline $\mathrm{H}$ & 0.000002489 & -0.000015014 & -0.000019624 \\
\hline $\mathrm{H}$ & -0.000002381 & -0.000004717 & -0.000019158 \\
\hline $\mathrm{H}$ & -0.000000661 & 0.000021677 & 0.0000 \\
\hline $\mathrm{H}$ & -0.000009387 & 0.000016113 & 0.00001222 \\
\hline & -0.000015173 & -0.000039878 & -0.000023344 \\
\hline $\mathrm{H}$ & -0.000004332 & -0.000003814 & -0.000016121 \\
\hline $\mathrm{H}$ & 0.000014953 & -0.000016299 & 0.0000082 \\
\hline
\end{tabular}




$\begin{array}{llll}\mathrm{H} & 0.000007262 & -0.000018124 & 0.000022884 \\ \mathrm{H} & 0.000012706 & 0.000008853 & 0.000007106 \\ \mathrm{H} & -0.000017874 & 0.000014369 & -0.000005107 \\ \mathrm{H} & -0.000029783 & 0.000004306 & 0.000001018 \\ \mathrm{H} & 0.000006706 & -0.000002759 & 0.000013894 \\ \mathrm{H} & -0.000023373 & -0.000014108 & 0.00001523 \\ \mathrm{H} & -0.00001111 & 0.000020264 & 0.000018324 \\ \mathrm{H} & -0.000014477 & -0.000001998 & -0.000005579 \\ \mathrm{H} & -0.000015011 & -0.000009288 & 0.000025749 \\ \mathrm{H} & -0.000003458 & -0.000029162 & -0.000002742\end{array}$

EEE-isomer

$\begin{array}{llll}\mathrm{C} & -0.295827 & 2.199712 & 0.317868 \\ \mathrm{C} & -1.468785 & 2.203143 & 0.989051 \\ \mathrm{C} & -2.190617 & 3.320008 & 1.172845 \\ \mathrm{C} & -1.762791 & 4.488021 & 0.675853 \\ \mathrm{C} & -0.61087 & 4.516694 & -0.007017 \\ \mathrm{C} & 0.099874 & 3.390892 & -0.178952 \\ \mathrm{C} & 0.414135 & 1.054194 & 0.134384 \\ \mathrm{C} & 1.771831 & 1.055814 & 0.00459 \\ \mathrm{C} & -0.267183 & -0.126379 & 0.121379 \\ \mathrm{C} & 0.252634 & -1.183822 & 0.802731 \\ \mathrm{C} & 1.062756 & -1.005812 & 1.86967 \\ \mathrm{C} & 1.602144 & -2.033373 & 2.544207 \\ \mathrm{C} & 1.353953 & -3.293479 & 2.163696 \\ \mathrm{C} & 0.56633 & -3.504641 & 1.101012 \\ \mathrm{C} & 0.032937 & -2.466019 & 0.438489 \\ \mathrm{C} & -1.436547 & -0.201488 & -0.575404 \\ \mathrm{C} & -2.405994 & -1.067486 & -0.197587 \\ \mathrm{C} & -1.670917 & 0.747548 & -1.743397 \\ \mathrm{C} & 2.378126 & 0.034721 & -0.647249 \\ \mathrm{C} & 2.604739 & 2.180947 & 0.600702 \\ \mathrm{C} & 3.701675 & -0.192518 & -0.896624 \\ \mathrm{C} & -3.642932 & -1.292221 & -0.731312 \\ \mathrm{O} & -4.448215 & -2.231894 & -0.127833 \\ \mathrm{O} & 4.042432 & -1.329102 & -1.595383 \\ \mathrm{O} & 4.581861 & 0.559543 & -0.532353 \\ \mathrm{C} & 5.404509 & -1.581497 & -1.849352 \\ \mathrm{O} & -4.058189 & -0.701103 & -1.70674 \\ \mathrm{C} & -5.728002 & -2.468931 & -0.665955 \\ \mathrm{H} & -1.870586 & 1.287231 & 1.454444 \\ \mathrm{H} & -3.136296 & 3.281379 & 1.739843 \\ \mathrm{H} & -2.353633 & 5.407915 & 0.818036 \\ \mathrm{H} & -0.259725 & 5.46628 & -0.445381 \\ \mathrm{H} & 1.002569 & 3.479342 & -0.804629\end{array}$




$\begin{array}{llll}\mathrm{H} & 1.288892 & 0.000617 & 2.260902 \\ \mathrm{H} & 2.247377 & -1.844346 & 3.418898 \\ \mathrm{H} & 1.798455 & -4.141882 & 2.709642 \\ \mathrm{H} & 0.375375 & -4.536424 & 0.760081 \\ \mathrm{H} & -0.551903 & -2.717385 & -0.462526 \\ \mathrm{H} & -2.257206 & -1.685818 & 0.705434 \\ \mathrm{H} & -0.773193 & 1.327934 & -2.046106 \\ \mathrm{H} & -1.897961 & 0.169736 & -2.667304 \\ \mathrm{H} & -2.492206 & 1.470832 & -1.537927 \\ \mathrm{H} & 1.762241 & -0.758816 & -1.106863 \\ \mathrm{H} & 2.038837 & 2.852414 & 1.281591 \\ \mathrm{H} & 3.369583 & 1.76198 & 1.29258 \\ \mathrm{H} & 3.10886 & 2.795046 & -0.179245 \\ \mathrm{H} & 5.474403 & -2.538178 & -2.413812 \\ \mathrm{H} & 5.836357 & -0.768417 & -2.474817 \\ \mathrm{H} & 5.95993 & -1.693877 & -0.891363 \\ \mathrm{H} & -6.219261 & -3.251462 & -0.045602 \\ \mathrm{H} & -6.342552 & -1.542013 & -0.619426 \\ \mathrm{H} & -5.642533 & -2.845807 & -1.70975\end{array}$




\section{REFERENCES}

(1) Berkowski, K. L.; Potisek, S. L.; Hickenboth, C. R.; Moore, J. S. Ultrasound-Induced Site-Specific Cleavage of Azo-Functionalized Poly(ethylene glycol). Macromolecules 2005, 38, 8975 .

(2) Frisch, M. J.; Trucks, G. W.; Schlegel, H. B.; Scuseria, G. E.; Robb, M. A.; Cheeseman, J. R.; Scalmani, G.; Barone, V.; Mennucci, B.; Petersson, G. A.; Nakatsuji, H.; Caricato, M.; Li, X.; Hratchian, H. P.; Izmaylov, A. F.; Bloino, J.; Zheng, G.; Sonnenberg, J. L.; Hada, M.; Ehara, M.; Toyota, K.; Fukuda, R.; Hasegawa, J.; Ishida, M.; Nakajima, T.; Honda, Y.; Kitao, O.; Nakai, H.; Vreven, T.; Montgomery, Jr., J. A.; Peralta, J. E.; Ogliaro, F.; Bearpark, M.; Heyd, J. J.; Brothers, E.; Kudin, K. N.; Staroverov, V. N.; Keith, T.; Kobayashi, R.; Normand, J.; Raghavachari, K.; Rendell, A.; Burant, J. C.; Iyengar, S. S.; Tomasi, J.; Cossi, M.; Rega, N.; Millam, J. M.; Klene, M.; Knox, J. E.; Cross, J. B.; Bakken, V.; Adamo, C.; Jaramillo, J.; Gomperts, R.; Stratmann, R. E.; Yazyev, O.; Austin, A. J.; Cammi, R.; Pomelli, C.; Ochterski, J. W.; Martin, R. L.; Morokuma, K.; Zakrzewski, V. G.; Voth, G. A.; Salvador, P.; Dannenberg, J. J.;Dapprich, S.;Daniels, A. D.; Farkas, O.; Foresman, J. B.; Ortiz, J. V.; Cioslowski, J.; Fox, D. J. (2010). Gaussian 09, Revision B.01; Gaussian Inc.: Wallingford, CT.

(3) Yang, J.S.; Huang, H.H.; Lin, S.H. Facile Multistep Synthesis of Isotruxene and Isotruxenone J. Org. Chem. 2009, 74, 3974.

(4) Hans Reich's Collection. NMR Spectroscopy.

https://organicchemistrydata.org/hansreich/resources/nmr/?page=06-cmr-06-2jch\%2F (accessed Oct 18, 2021)

(5) Hansen, S.; Ulven, T. Oxalyl Chloride as a Practical Carnbon Monoxide Source for Carbonylation Reactions. Org. Lett. 2015, 17, 2832.

(6) Lenhardt, J. M.; Black Ramirez, A. L.; Lee, B.; Kouznetsova, T. B.; Craig, S. L. Mechanistic Insights into the Sonochemical Activation of Multimechanophore Cyclopropanated Polybutadiene Polymers. Macromolecules 2015, 48, 6396.

(7) Hsu, T. G.; Zhou, J.; Su, H. W.; Schrage, B. R.; Ziegler, C. J.; Wang, J. A Polymer with "Locked" Degradability: Superior Backbone Stability and Accessible Degradability Enabled by Mechanophore Installation. J. Am. Chem. Soc. 2020, 142, 5, 2100-2104.

(8) Bruker (2018). APEX3. Bruker AXS, Inc., Madison, Wisconsin, USA.

(9) Krause, L., Herbst-Irmer, R., Sheldrick, G. M. and Stalke, D. Comparison of silver and molybdenum microfocus X-ray sources for single-crystal structure determination. J. Appl. Cryst., 2015, 48, 3-10.

(10) Sheldrick, G. M. SHELXT - Integrated space-group and crystal-structure determination. Acta Cryst. 2015, A71, 3-8.

(11) Sheldrick, G. M. Crystal Structure Refinement with SHELXL. Acta Cryst. 2015, C71, 3-8.

(12) Suslick, K. S. "Sonochemistry," Science 1990, 247, 1439. 